\author{
UNIVERSIDADE DE SÃO PAULO \\ FACULDADE DE FILOSOFIA, LETRAS E CIÊNCIAS HUMANAS \\ DEPARTAMENTO DE LETRAS CLÁSSICAS E VERNÁCULAS \\ PROGRAMA DE PÓS-GRADUAÇÃO EM FILOLOGIA E LÍNGUA \\ PORTUGUESA
}

\title{
VALORES E FUNÇÕES DOS ADVÉRBIOS LOCATIVOS NO PORTUGUÊS POPULAR BRASILEIRO
}

\author{
Raquel Marcondes Nogueira
}

Orientadora: Profa. Dra. Angela Cecília de Souza Rodrigues

\begin{abstract}
Dissertação apresentada ao Programa de Pós-Graduação em Filologia e Língua Portuguesa do Departamento de Letras Clássicas e Vernáculas da Faculdade de Filosofia, Letras e Ciências Humanas da Universidade de São Paulo, para obtenção do título de Mestre em Letras.
\end{abstract}

\section{SÃO PAULO}

\section{pdfMachine}

A pdf writer that produces quality PDF files with ease!

Produce quality PDF files in seconds and preserve the integrity of your original documents. Compatible across nearly all Windows platforms, simply open the document you want to convert, click "print", select the 


\section{$\underline{\text { Agradecimentos }}$}

A minha querida Profa. Dra. Ângela Cecília de Souza Rodrigues, pela dedicação, empenho, incentivo e carinho dedicados a mim.

A meus pais e a minha madrinha, pelo exemplo de vida, amor e confiança inabalável.

Ao meu namorado e amigos, que contribuíram de forma direta ou indireta para a concretização deste trabalho.

Ao $\mathrm{CNPq}$, que proporcionou os recursos financeiros necessários para a realização desta pesquisa.

\section{pdfMachine}

A pdf writer that produces quality PDF files with ease!

Produce quality PDF files in seconds and preserve the integrity of your original documents. Compatible across

nearly all Windows platforms, simply open the document you want to convert, click "print", select the

"Broadgun pdfMachine printer" and that's it! Get yours now! 


\section{RESUMO}

Neste trabalho, buscamos analisar, de um ponto vista sincrônico e quantitativo, as funções que os locativos aqui, aí, ali e lá exercem na oração e no texto. Para isso, trabalhamos com a variedade do português popular falado no Brasil, mais especificamente o dialeto utilizado pelos informantes do projeto Filologia Bandeirante (MEGALE, 1998) e pelos falantes que forneceram material para organização do Banco de Dados do Português Popular Falado na Cidade de São Paulo (RODRIGUES, 1987).

A principal questão analisada foi a da função sintática dos advérbios locativos, ou seja, se seriam sempre adjuntos, como algumas Gramáticas Tradicionais (GT) acreditam ou se poderiam exercer a função de argumentos de predicado, como alguns estudos já apontam. Adotando os pressupostos teórico-metodológicos da Gramática Funcional de DIK (1989) e da Sociolingüística Variacionista, nosso objetivo é descrever, analisar e explicar o comportamento dos locativos, buscando identificar os possíveis contextos que favoreçam o aparecimento destes termos ora como argumento, ora como satélites de EsCo.

PALAVRAS-CHAVE: locativos adverbiais, contextos de uso, português popular, Gramática Funcional, Sociolingüística. 


\begin{abstract}
In this research we analyze, of a point sight synchronic and quantitative, the functions that the locative case aqui, aí, ali and lá are used in the sentence and in the text. For that, we work with the range of the Portuguese popular spoken in Brazil, more specifically the dialect utilized by the informers of the Filologia Bandeirante project (MEGALE, 1998) and by the talkative that supplied stuff for organization of the Banco de Dados do Português Popular Falado na Cidade de São Paulo (RODRIGUES, 1987).

The main question analyzed was the syntactic function of the adverbs locative case, for instance if would be always adjunct, as some Traditional Grammar (GT) believe or it would be able to exercise the predicate arguments function, like some studies already aim. Adopting the theoretical-methodological budgets of the Functional Grammar of DIK (1989) and of the Sociolinguistics Variationist, our objective is going to describe, analyze and explain the behavior of the locative case, seeking identify the possible contexts that favor the appearance of these we will have as argument, or on the other hand like satellites of EsCo.
\end{abstract}

KEYWORDS: locative adverb, contexts of use, Portuguese popular, Functional Grammar, Sociolinguistics. 


\section{SUMÁRIO}

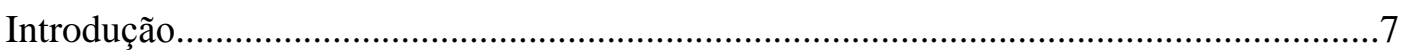

Capítulo 1: Pressupostos teórico metodológicos........................................................

1.1 O Funcionalismo de Simon Dik................................................................14

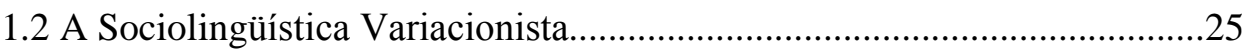

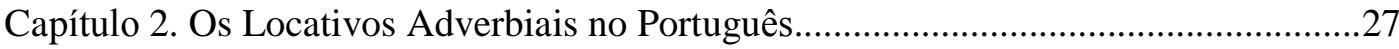

2.1 Os advérbios na Gramática Tradicional.................................................27

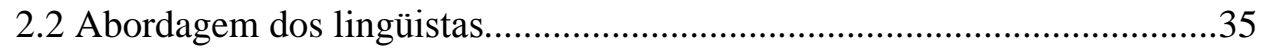

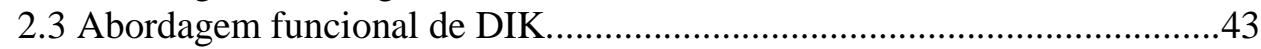

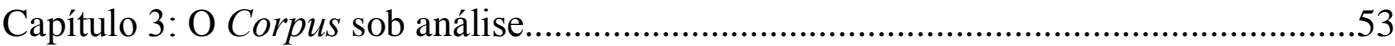

3.1 O Projeto Filologia Bandeirante................................................................53

3.2 Banco de Dados do Português Popular Falado na Cidade de São Paulo.....54

3.3 Perfil Social dos Informantes..................................................................54

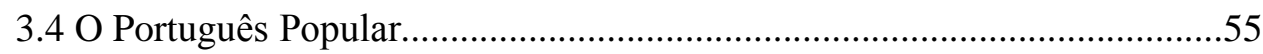

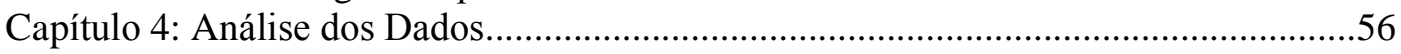

4.1 Locativos e função de Argumento e Satélite.............................................57

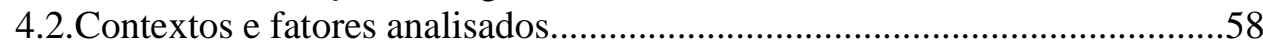

4.2.1. Tipos de EsCos.........................................................................60

4.2.2 Posição dos advérbios....................................................................60

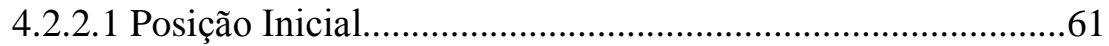

4.2.2.2 Posição Antes do Verbo...........................................................61

4.2.2.3 Posição Depois do Verbo...........................................................62

4.2.2.4 Posição Depois do Objeto.....................................................62

4.2.3 Troca de posição...................................................................63

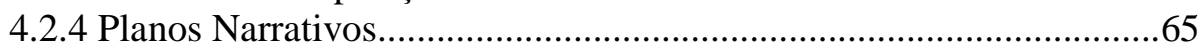

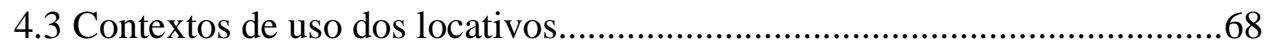

4.3.1 Os locativos e as funções de Argumento e Satélite............................68

4.4 Os EsCos e as funções argumento e satélite..................................................69

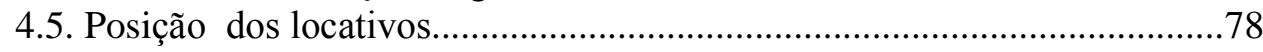

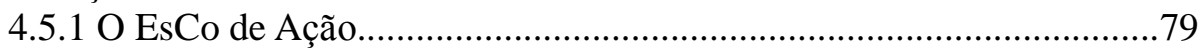

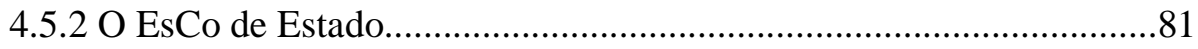

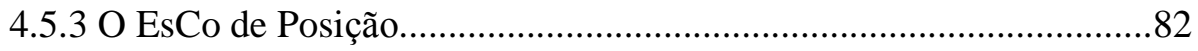

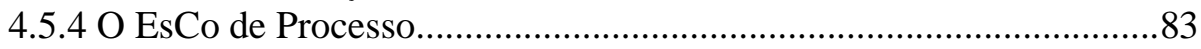

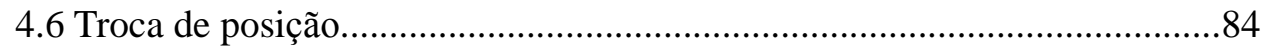

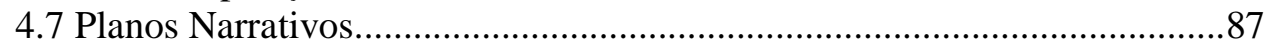

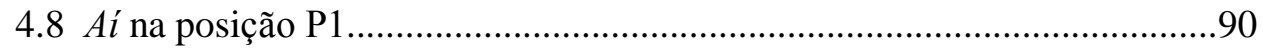

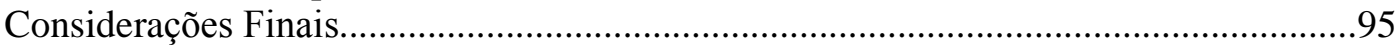

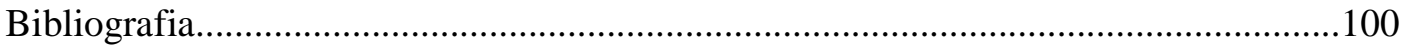




\section{ÍNDICE DE QUADROS}

1. Gramática Formal X Gramática Funcional. (M. A. K. Halliday, 1985, Introduction. Adaptação M. H. M. Neves 1994.).................................................9

2. Quadro resumo que explica os paradigmas formal e funcional...........................13

3. A predicação, seu predicado e termos.............................................................

4. O papel semântico de cada um dos termos da oração..........................................17

5. Parâmetros semânticos para uma tipologia do EsCo..........................................20

6. Quadro resumo sobre categorização e função dos advérbios de acordo com

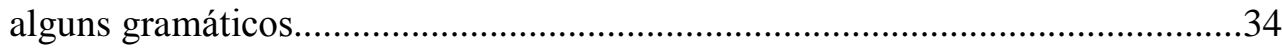

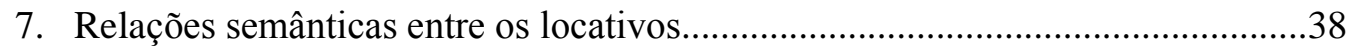

8. Hierarquia das Funções Semânticas (DIK,1989)..............................................49

\section{ÍNDICE DE TABELAS}

1. Função que os locativos desempenham na oração................................................68

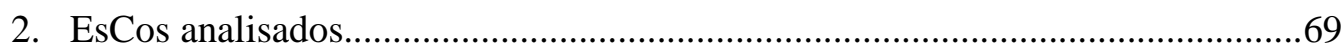

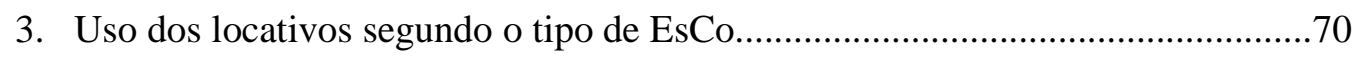

4. Uso dos locativos segundo sua posição na oração.................................................78

5. Frequência dos locativos que expressam EsCo de Ação e sua posição.................79

6. Frequência dos locativos que expressam EsCo de Estado e sua posição..............81

7. Frequência dos locativos que expressam EsCo de Posição e sua posição.............82

8. Frequência dos locativos que expressam EsCo de Processo e sua posição...........83

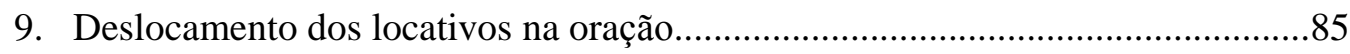

10. Freqüência do locativo segundo sua posição e possibilidade de deslocamento...86

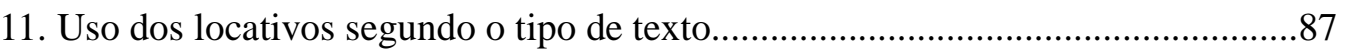

12. Uso dos locativos segundo os EsCos e os planos narrativos..............................88 


\section{INTRODUÇÃO}

Este trabalho tem por objetivo discutir as funções que os advérbios locativos, mais precisamente aqui, aí, ali e lá, desempenham na oração e no texto. A principal questão analisada aqui é se os advérbios locativos são sempre adjuntos ou também podem exercer a função de argumentos de predicado. Buscaremos verificar também:

1. quais os Estados de Coisas (EsCo) ${ }^{1}$ em que os locativos mais aparecem;

2. a questão da mobilidade dos locativos adverbias na oração;

3. o uso dos locativos em textos narrativos.

Por tudo isso, a perspectiva teórica adotada é a da Gramática Funcional de Simon Dik.

Ainda nesta pesquisa, verificamos como a Gramática Tradicional (GT) tem abordado esse assunto, uma vez que alguns de seus autores já apontam os locativos como possíveis argumentos de predicado.

Os dados analisados foram retirados de inquéritos que são parte integrante do corpus do Projeto Filologia Bandeirante, coordenado por Megale (1998), e do Banco de Dados do Português Popular Falado na Cidade de São Paulo, organizado por Rodrigues (1987).

O trabalho apresenta-se dividido em quatro capítulos. O primeiro apresenta informação sobre a teoria funcionalista de Dik (1989) e dá pequena notícia sobre a Sociolingüística Variacionista Laboviana, que também fornece subsídios para esta dissertação.

O capítulo 2 compreende uma resenha de trabalhos sobre os advérbios locativos, ressaltando aspectos considerados importantes para o desenvolvimento da presente pesquisa. Para a confecção deste capítulo, levou-se em consideração a abordagem das gramáticas tradicionais e a abordagem dos lingüistas.

No capítulo 3, fazemos uma apresentação do corpus sob análise, bem como das características sociais dos informantes cujos inquéritos são estudados.

O capítulo 4 corresponde à parte nuclear da dissertação e abrange a descrição, a análise e a interpretação dos dados. Tomando por base os resultados dos cálculos fornecidos por alguns programas do pacote Goldvarb, versão mais recente do pacote de

${ }^{1}$ A Predicação Nuclear como um todo designa um conjunto de Estado de Coisas (EsCo). O termo Estado de Coisas é usado no sentido amplo de 'concepção de alguma coisa que pode ocorrer em algum mundo', é 
programas Varbrul, discorremos, neste capítulo, sobre os contextos em que os advérbios locativos aparecem ora como satélites ora como argumentos.

Em Considerações Finais, retomam-se os resultados mais relevantes da pesquisa e fazemos algumas sugestões de estudos futuros.

Esperamos que a realização deste trabalho possa contribuir para uma melhor caracterização e compreensão dos advérbios no português popular falado do Brasil. Tal classe é bastante heterogênea como afirma Ilari (1991: 134) "uma classe extremamente heterogênea que se caracteriza pelo seu caráter extremamente variado das funções sintáticas que exercem e dos ambientes sintáticos em que ocorrem”.

Cabe ressaltar, ainda, que o estudo do Português Popular Brasileiro fornece importantes subsídios não só ao pesquisador, como também ao futuro professor que venha a se engajar em projetos de alfabetização de adultos, tendo em vista que o conhecimento da variedade utilizada pelo público-alvo permite ao professor ensinar a partir do uso lingüístico observado, o que facilita sobremaneira a aquisição, por parte do aluno, da variedade padrão. 


\section{CAPÍTULO 1 \\ PRESSUPOSTOS TEÓRICO - METODOLÓGICOS}

Acontece uma polarização quando se trata de abordagens formalistas e funcionalistas, segundo Halliday (1985). Para os funcionalistas interessa a função das formas lingüísticas, enquanto para os formalistas a análise da forma lingüística parece ser mais relevante. Abaixo estão as diferenças básicas entre essas duas correntes de estudo, segundo o autor.

\begin{tabular}{|l|l|}
\hline \multicolumn{1}{|c|}{ GRAMÁTICA FORMAL } & \multicolumn{1}{|c|}{ GRAMÁTICA FUNCIONAL } \\
\hline Orientação primariamente sintagmática. & Orientação primariamente paradigmática. \\
\hline $\begin{array}{l}\text { Interpretação da língua como um conjunto } \\
\text { de estruturas entre as quais podem ser } \\
\text { estabelecidas relações regulares. }\end{array}$ & $\begin{array}{l}\text { Interpretação da língua como uma rede de } \\
\text { ligações: as estruturas como interpretação } \\
\text { das relações. }\end{array}$ \\
\hline $\begin{array}{l}\text { Ênfase nos traços universais da língua } \\
\text { (sintaxe como base: organização em torno }\end{array}$ & $\begin{array}{l}\text { Enfase nas variações entre as línguas } \\
\text { diferentes (semântica como base: } \\
\text { da frase). }\end{array}$ \\
$\begin{array}{l}\text { organização em torno do texto ou } \\
\text { discurso). }\end{array}$ \\
\hline
\end{tabular}

Quadro 1: Gramática Formal X Gramática Funcional. (M. A. K. Halliday, 1985, Introduction. Adaptação M. H. M.

Neves 1994.)

De acordo com Dillinger (1991), enquanto o Formalismo se refere ao estudo das formas lingüísticas, o Funcionalismo se refere ao estudo do significado e do uso das formas lingüísticas em atos comunicativos. Em outras palavras, o Formalismo vê a língua como um sistema autônomo, enquanto o Funcionalismo vê a língua como um sistema não-autônomo, inserido em um contexto de interação social.

Vemos, dessa forma, que há diferentes maneiras de se estudar o mesmo objeto. Por isso, é importante que discorramos um pouco mais sobre cada uma dessas duas grandes correntes de estudo, sobretudo sobre o Funcionalismo, que é a corrente de pensamento que dá suporte a este trabalho.

O Formalismo considera que as concepções lingüísticas devem ser formuladas sem levar em consideração quaisquer interferências extralingüísticas, ou seja, sem considerar interferências sociais ou pragmáticas que possam incidir sobre a forma. 
Castilho (1994: 76) afirma que a sintaxe gerativa interpreta a língua como uma atividade mental e a Sintaxe Estrutural a interpreta como um sistema. Nesse sentido, ambas se afastam da sintaxe funcional que postula a língua como uma atividade social.

Podemos perceber que o formalismo considera a linguagem, mais especificamente, a sintaxe como um objeto autônomo. Dessa forma, parte do processo de análise lingüística sob o ponto de vista formal é feito considerando-se apenas a sentença, ou seja, apenas fatores internos, como explica Berlinck et al. (2002:212)

Os fenômenos de variação e mudanças lingüísticas, observáveis, por exemplo, na questão da ordem em que se apresentam os constituintes sintáticos de uma sentença, deverão ser tratados em termos de propriedades internas ao sistema lingüístico ou de possibilidades de variação que se verificam nesse mesmo sistema.

O programa de Chomsky (1986), representante desta perspectiva de análise, teve como ponto de partida a exploração de quatro questões principais. São elas:

a) No que consiste o sistema de conhecimentos do falante de uma determinada língua particular?

b) Como se dá o desenvolvimento de tal sistema de conhecimentos na mente do falante?

c) De que forma o falante utiliza tal sistema em situações discursivas concretas?

d) Que mecanismos físicos do cérebro do falante servem de base a tal sistema de conhecimentos?

Chomsky adota uma perspectiva formalista para a análise dos dados lingüísticos, tentando pelo estudo da língua, em termos de suas partes, determinar os princípios de sua organização, para só então estabelecer as relações entre elas e seu uso.

Além disso, o formalismo segue o método dedutivo, que se baseia na introspecção do lingüista, argumenta em favor de uma base inatista para o processo de aquisição e trata os fatos lingüísticos de forma modular.

Pezatti (1994:38) prefere estabelecer a distinção entre formalismo e funcionalismo levando em consideração três áreas propostas por Labov (1987) (i) posições teóricas específicas, (ii) política geral e (iii) posições ideológicas.

A autora explica que no que se refere às posições teóricas, o formalismo entende a linguagem como um objeto abstrato, que sobrepõe o estudo da sintaxe ao da semântica e ao da pragmática.

A pdf writer that produces quality PDF files with ease!

Produce quality PDF files in seconds and preserve the integrity of your original documents. Compatible across nearly all Windows platforms, simply open the document you want to convert, click "print", select the "Broadgun pdfMachine printer" and that's it! Get yours now! 
Num enfoque formalista, a prioridade metodológica é a da sintaxe em relação à semântica, e desta em relação à pragmática. O princípio que rege essa escala baseia-se no fato de que, somente depois que o sistema de regras formais, de natureza sintática, tiver sido bem estabelecido, é possível estudar o significado das estruturas sintáticas abstratas e os usos delas em circunstâncias reais de comunicação. (PEZATTI, 1994:38).

Quanto à política geral, o enfoque formalista prioriza o estudo da competência (Língua I) em detrimento do estudo o desempenho (língua E). Esse paralelo nos leva a outro baseado na relação entre linguagem e contexto social. O ponto de vista formalista admite que uma sentença deva ser estudada independentemente do contexto social no qual ela está inserida, ou seja, não se leva em consideração o uso.

Por último, quanto à questão de posição ideológica, deve-se levar em consideração a aquisição da linguagem e os universais lingüísticos. Os formalistas consideram que a criança constrói a gramática da língua que aprende com base em propriedades inatas e, por sua vez, como universais lingüísticos. O inatismo é a concepção de que há uma dotação genética que nos capacita a adquirir e a usar uma língua. A visão de aquisição, no âmbito da proposta de Princípios e Parâmetros, que constitui a Gramática Universal, conforme explicam Mioto el al.(2000: 31) "prevê que a tarefa da criança ao adquirir uma língua é a de 'marcar' de alguma forma aquilo que é específico a sua língua, dadas determinadas possibilidades pré-existentes e, assim, desenvolver um certo sistema de conhecimento, representado de alguma forma em sua mente".

Quando o autor fala em "sistema de conhecimentos" está considerando uma determinada concepção de linguagem que, para a gramática gerativa de Chomsky, tratase da Língua I, ou seja, a língua "interna" de um determinado falante, algo interno à mente, um saber individual inconsciente.

Os mesmos critérios adotados para determinar o que é o formalismo também serão empregados para traçar algumas características do funcionalismo.

O funcionalismo considera que a linguagem se define inteiramente como um instrumento de interação social empregado por seres humanos com o propósito de estabelecer a comunicação entre os interlocutores. A interação verbal é uma atividade cooperativa estruturada em termos de regras sociais. As expressões lingüísticas, instrumentos usados na atividade cooperativa estruturada, também são estruturadas, no 
sentido de que são regidas por regras. Assim, tanto as regras sociais como as regras lingüísticas estão subjacentes à interação verbal. Dik (1989) entende que as regras propriamente lingüísticas devem ser consideradas instrumentais com relação aos objetivos comunicativos da interação verbal.

Assim, para os funcionalistas o fato de a comunicação ser uma função fundamental da linguagem determina o modo como a língua será estruturada. Dessa maneira, a análise lingüística sob o ponto de vista funcionalista deve levar em consideração tanto a bagagem pragmática do falante como do ouvinte, além do contexto social no qual estão inseridos. Halliday (1978: 16 apud BERLINCK et al. 2000) afirma que "tenta-se explicar a natureza da linguagem, a sua organização interna, em termos das funções que ela desenvolveu para servir na vida do homem social".

Quanto à política geral, o funcionalismo considera essencial priorizar o estudo do uso e não do sistema lingüístico. Para os funcionalistas, é necessário que se descreva, em uma análise lingüística, as expressões verbais em seus contextos sociais específicos.

Vemos, dessa forma, que no funcionalismo a análise deve ser expandida para além dos limites da sentença. A sintaxe, nesse modelo, não é considerada autônoma, uma vez que estabelece relações com os componentes semânticos e pragmáticos. Berlinck et al. (2000:212) afirmam que "só é possível compreender o que se passa na sintaxe, olhando também para o contexto (texto e/ou situação comunicativa) em que a sentença está inserida. É nesse espaço ampliado de análise que se vão buscar as motivações das escolhas que o falante faz em termos estruturais”.

A posição ideológica dos funcionalistas considera que a criança desenvolve o sistema lingüístico subjacente ao uso, mediante a exposição a um conjunto altamente estruturado de dados em contextos naturais, e adaptado ao nível de desenvolvimento de sua competência comunicativa.

Para que a exposição se torne mais clara vale apresentar o conhecido quadro resumo proposto por Dik na adaptação de Neves (1994:46-47). 


\begin{tabular}{|c|c|c|}
\hline & $\begin{array}{l}\text { PARADIGMA } \\
\text { FORMAL }\end{array}$ & $\begin{array}{l}\text { PARADIGMA } \\
\text { FUNCIONAL }\end{array}$ \\
\hline Como definir a língua & Conjunto de orações. & $\begin{array}{l}\text { Instrumento de interação } \\
\text { social. }\end{array}$ \\
\hline Principal função da língua & Expressão dos pensamentos. & Comunicação. \\
\hline Correlato Psicológico & $\begin{array}{l}\text { Competência: capacidade de } \\
\text { produzir e julgar orações. }\end{array}$ & $\begin{array}{l}\text { Competência comunicativa: } \\
\text { habilidade de interagir } \\
\text { socialmente com a língua. }\end{array}$ \\
\hline O sistema e seu uso & $\begin{array}{l}\text { O estudo da competência tem } \\
\text { prioridade sobre o da atuação. }\end{array}$ & $\begin{array}{l}\text { O estudo do sistema deve } \\
\text { fazer-se dentro do quadro do } \\
\text { uso. }\end{array}$ \\
\hline Língua e contexto /situação & $\begin{array}{l}\text { As orações da língua devem } \\
\text { descrever-se } \\
\text { independentemente do } \\
\text { contexto/situação. }\end{array}$ & $\begin{array}{l}\text { A descrição das expressões } \\
\text { deve fornecer dados para a } \\
\text { descrição de seu } \\
\text { funcionamento num dado } \\
\text { contexto. }\end{array}$ \\
\hline Aquisição da linguagem & $\begin{array}{l}\text { Faz-se com o uso de } \\
\text { propriedades inatas, com base } \\
\text { em um input restrito e não- } \\
\text { estruturado de dados. }\end{array}$ & $\begin{array}{l}\text { Faz-se com a ajuda de um } \\
\text { input extenso e estruturado de } \\
\text { dados apresentado no } \\
\text { contexto natural. }\end{array}$ \\
\hline Universais lingüísticos & $\begin{array}{l}\text { Propriedades inatas do } \\
\text { organismo humano. }\end{array}$ & $\begin{array}{l}\text { Explicados em função de } \\
\text { restrições: comunicativas; } \\
\text { biológicas ou psicológicas; } \\
\text { contextuais. }\end{array}$ \\
\hline $\begin{array}{l}\text { Relação entre a sintaxe, a } \\
\text { semântica e a pragmática. }\end{array}$ & $\begin{array}{l}\text { A sintaxe é autônoma em } \\
\text { relação à semântica; as duas } \\
\text { são autônomas em relação à } \\
\text { pragmática; as prioridades } \\
\text { vão da sintaxe à pragmática, } \\
\text { via semântica. }\end{array}$ & $\begin{array}{l}\text { A pragmática é o quadro } \\
\text { dentro do qual a semântica e } \\
\text { a sintaxe devem ser } \\
\text { estudadas; as prioridades vão } \\
\text { da pragmática à sintaxe, via } \\
\text { semântica. }\end{array}$ \\
\hline
\end{tabular}

Quadro 2: Quadro resumo que explica os paradigmas formal e funcional In: NEVES, M.H.M. A Gramática

Funcional. São Paulo, Ed. Martins Fontes. 1997

Tal distinção realizada neste trabalho teve por objetivo mostrar, de forma generalizada, abordagens que para uns podem ser complementares, enquanto para outros alternativas. Não há apenas um tipo de formalismo como não há apenas um 
Os contrastes entre as várias perspectivas do funcionalismo se assemelham aos contrastes encontrados nas várias abordagens formalistas (...) Mesmo na visão funcionalista, temos os correlatos da Língua-I e da Língua E de Chomsky (1986), para quem Língua I é a representação da competência sintática do falante e LínguaE é o objeto gramatical externo, observável. A diferença é que na visão-I(interna, individual e intensional) do funcionalista, o que se estuda são os processos mentais que entram em jogo no uso da língua e não apenas o conhecimento estrutural do enunciados, e na visão-E (externa e extensional), leva-se em conta a Língua-E em contexto.

Dentre os modelos de estudo optou-se pelo funcionalismo moderado de Simon Dik para dar suporte a este trabalho.

\subsection{O FUNCIONALISMO DE SIMON DIK}

Segundo Dik (1989) quando se adota um ponto de vista funcionalista no estudo de uma língua natural, a principal questão de interresse é a seguinte: “Como 'opera' o usuário da língua natural (ULN)?” Ou seja, como falante e ouvinte conseguem comunicar-se com sucesso por meio de expressões lingüísticas?

O mesmo Dik explica que, no modelo da gramática funcional, o uso comunicativo da língua envolve níveis mais elevados do que a função lingüística. Devem ser consideradas as seguintes capacidades humanas: (DIK, 1989: 1).

1. Capacidade lingüística: o ULN é capaz de produzir e interpretar corretamente expressões lingüísticas de grande complexidade e variedade estrutural em um grande número de situações comunicativas.

2. Capacidade epistêmica: o ULN é capaz de construir, manter e explorar uma base de conhecimento organizado; ele pode derivar conhecimento a partir de expressões lingüísticas, armazenar esse conhecimento de forma apropriada, recuperá-lo na interpretação de expressões lingüística posteriores.

3. Capacidade lógica: munido de certos conhecimentos, o ULN é capaz de deduzir novos conhecimentos a partir de raciocínio lógico, dedutivo e probabilístico.

4. Capacidade perceptual: o ULN é capaz de perceber seu ambiente, derivar conhecimento a partir de suas percepções e usar este conhecimento não só na produção como também na interpretação de expressões lingüísticas. 
5. Capacidade Social: o ULN não somente sabe o que dizer a um determinado interlocutor, mas também como dizê-lo, em uma situação comunicativa particular, a fim de atingir metas comunicativas particulares.

A interação social neste modelo é vista como estruturada, uma vez que necessita de regras e convenções, e cooperativa, já que precisa de pelo menos dois participantes para que seja realizada. Os participantes envolvidos na interação precisam de instrumentos, que são as expressões lingüísticas, que também são entidades estruturadas. Dik (1989) afirma que as expressões lingüísticas não devem ser pensadas como objetos isolados, mas como instrumentos que são usados pelo falante para provocar no ouvinte a interpretação que deseja.

Sob o ponto de vista funcional a análise envolve dois tipos de sistemas de regras:

(i) as regras que governam a constituição das expressões lingüísticas (regras semânticas, sintáticas, morfológicas e fonológicas);

(ii) as regras que governam os padrões de interação verbal em que essas expressões lingüísticas são usadas (regras pragmáticas).

O sistema de regras (i) deve ser visto como instrumental ao sistema de regras (ii), já que no paradigma funcional as expressões lingüísticas devem ser vistas e explicadas em função da interação verbal entre falante, ouvinte e o contexto sociocultural no qual estão inseridos. Sob o ponto de vista de Dik (1989), as expressões lingüísticas são vistas como meras mediações entre a intenção do falante/destinador e a interpretação do ouvinte/destinatário.

No modelo de Dik (1989), todos os itens lexicais devem ser analisados dentro da predicação. Todos os predicados básicos de uma língua compõem o seu léxico.

Para Dik (1989), a oração deve ser descrita em termos de estrutura subjacente abstrata de oração, que é mapeada na forma real da expressão lingüística correspondente por um sistema de regras de expressão, conforme o esquema: 


\section{ESTRUTURA SUBJACENTE DA ORAÇÃO}

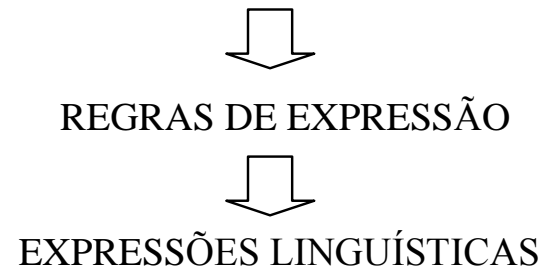

Para o autor, a descrição de uma expressão lingüística começa pela predicação subjacente que é, então, projetada na forma de expressão por meio de regras que determinam a forma e a ordem que os constituintes da predicação subjacente são realizados.

Para a formação da predicação subjacente, é necessária a inclusão de termos em estruturas de predicados, que constituem juntos, assim, o fundo da língua. Vale explicar que os termos são entidades que são usadas para fazer referência em algum mundo possível e os esquemas de predicados são estruturas que especificam um predicado juntamente com o esqueleto das estruturas nas quais ele pode aparecer.

Dentro do fundo está o léxico de uma língua. No léxico estão os termos básicos e os predicados básicos, que podem formar, por regras bastante produtivas, novos termos e novos predicados.

Neves (1994: 84) explica

A construção subjacente da cláusula, requer, pois antes de mais nada, um predicado. O predicado - que designa propriedades ou relações — se aplica a um certo número de termos - que se referem a entidades - produzindo uma predicação, que designa um estado-de-coisas, ou seja uma codificação lingüística ( e possivelmente cognitiva) que o falante faz da situação.

A predicação pode ser ilustrada pelo seguinte exemplo:

( 1 ) ele tá no Projeto Avizinhar...o Marcio... ele vai fazê... ele deu aula pro outro lá né... dá... vai... ele vai dá... ele tá dando plantão... ensinando lá

(PP. Inq. XIX:814 $)^{2}$

\footnotetext{
${ }^{2}$ Para identificarmos a ocorrência valemo-nos do seguinte código: PP indica que o inquérito sob análise pertence ao material do Projeto Português Popular, já FIL indica que o inquérito é parte integrante do material do Projeto Filologia Bandeirante. Em seguida, em número romano está o número do inquérito e, 


\begin{tabular}{|c|c|c|c|c|}
\cline { 2 - 5 } \multicolumn{1}{c|}{} & Termo & Predicado & Termo & Termo \\
\hline Predicação & Ele & dar & aula & outro \\
\hline Estado-de-Coisas & Entidade 1 & relação & Entidade2 & Entidade3 \\
\hline
\end{tabular}

Quadro 3: A predicação, seu predicado e termos.

Estabelece-se aí, uma relação de predicado com três entidades, que juntas designam um acontecimento, um fato em um mundo possível. Ou seja, admite-se a existência de um mundo no qual uma pessoa "Ele (Marcio)" dá uma coisa "aula" para uma outra pessoa "o outro". Cada entidade mencionada desempenha um papel semântico. Assim:

\begin{tabular}{|c|c|c|c|}
\hline Entidades & $\mathbf{1}$ & $\mathbf{2}$ & $\mathbf{3}$ \\
\hline Papel Semântico & agente & objeto & recebedor \\
\hline Termos & Ele (Marcio) & aula & outro \\
\hline
\end{tabular}

Quadro 4: O papel semântico de cada um dos termos da oração.

O predicado (dar) estabelece uma relação de três lugares como vimos. É necessário que alguém dê algo a outro alguém. Dessa maneira, observamos que o predicado foi aplicado a um conjunto apropriado de termos. A isso se chama predicação nuclear.

Um estado-de-coisas (doravante EsCo) é passível de acontecer em um determinado mundo, seja ele real ou imaginário e, dessa maneira, está sujeito a determinadas operações para localizá-lo no tempo ou no espaço. Também pode ser visto, ouvido ou percebido de alguma forma. Para que isso aconteça, lança-se mão dos operadores e satélites.

Visto isto, um operador de tempo como passado poderia localizar o EsCo apresentado.

\section{( 2 ) Passado\{[dar(Ele)(aula)(para o outro)]\}}

Se desejássemos também localizar este EsCo em um determinado espaço valernos-íamos de um satélite de lugar. Assim:

\section{( 3 ) Passado\{[(Ele)(dar)(aula)(para o outro)](lá)\}}

Os termos que são requeridos pela semântica do predicado, como (Ele), (aula) e (para o outro), são denominados argumentos do predicado, os termos que fornecem outras informações, tais como (lá), são chamados de satélites.

\section{pdfMachine}

A pdf writer that produces quality PDF files with ease!

Produce quality PDF files in seconds and preserve the integrity of your original documents. Compatible across nearly all Windows platforms, simply open the document you want to convert, click "print", select the "Broadgun pdfMachine printer" and that's it! Get yours now! 
Assim, os argumentos são termos exigidos por um predicado para formar uma predicação nuclear completa. São essenciais para a integridade dos EsCo designado pelo esquema de predicado. Se retirados, a propriedade/relação designada pelo predicado não é preenchida ou satisfeita.

Já os satélites são meios lexicais opcionais que veiculam informações adicionais a uma das camadas do modelo hierárquico da oração ${ }^{3}$. São opcionais, pois podem ser retirados sem afetar a gramaticalidade da oração, e lexicais, pois se opõem a outros meios gramaticais como tempo, modo e aspecto.

Os EsCo podem ser divididos em diferentes tipos de acordo com alguns parâmetros distintivos. Cada parâmetro mostra um determinado EsCo. Os mais importantes para uma tipologia semântica do EsCo são:

\pm Dinâmico $[ \pm \operatorname{din}]$

\pm Télico $[ \pm$ tel $]$

\pm Momentâneo $[ \pm$ mom]

\pm Controle [+con]

\pm Experiência $[ \pm \exp ]$

Um EsCo é [-din] ou Situação quando não envolve qualquer mudança. As entidades permanecem as mesmas durante o tempo do EsCo.

(4) ...e aquela menina que tá sentada ali é neta...mora aqui três neta comigo...

(FIL. Inq. VII: 12).

É considerado [+din] quando envolve necessariamente algum tipo de mudança no EsCo.

(5) ... mas ela ficô MUIto ruim... perdeu a memória ficô aquela coisa toda... .

(FIL. Inq. IV: 5)

No EsCo [+con], o $1^{\circ}$ argumento tem o poder de determinar a realização ou não do EsCo.

(6) ... a minha mãe fazia muito biscoito pra vendê....

(FIL. Inq. IV: 19)

Já quando o EsCo é [-con], o $1^{\circ}$ argumento não tem essa propriedade.

3 A estrutura subjacente da oração se organiza em "camadas" ou níveis. Essa organização em níveis se configura da seguinte maneira: Nível 1 - predicador e termos; Nível 2 - predicação; Nível 3 - proposição; Nível 4 - cláusula. A cada nível de unidade estrutural corresponde um diferente tipo de unidade 
(7) ...foi um negócio esquisito lá....a árvore perto da casa caiu...foi aquele tropelo...

(FIL. Inq. V: 45)

Um EsCo [+tel], se for totalmente efetuado, alcança um ponto terminal natural, indica evento completamente acabado.

(8) e no final eu nem fiquei com ele ...nem nada...já o pai dele eu: :: conheci ele lá tamém do otro lado...morei com ele e ti/fiquei grávida dele

(PP.Inq. XIII: 200)

Por outro lado, se o EsCo apresentar o traço [-tel] o evento ainda não acabou.

(9) os rapaiz tava comprano os pedaços de terra...parace que ali é bão... ${ }^{4}$

(FIL. Inq. VIII: 214)

O traço momentaneidade aparece dentro da categoria de eventos [+tel]. Isso porque situações e eventos [-tel] têm duração não limitada e eventos [+tel] apresentam duração limitada.

Assim, um evento que apresente o traço [+mom] indica que seu início coincide com o seu final. Já eventos que apresentam o traço [-mom] indicam que o evento ocupa um certo espaço de tempo.Tem início e fim distintos.

(10) João começou/continuou/acabou pintando o retrato. [-mom]

(11) A bomba explodiu. [+mom]

Por último, o traço [ $[ \pm \exp ]$ "subcategoriza todos estes tipos distinguidos por meio dos traços já considerados, marcando-os segundo haja, ou não, no estado de coisas, um ser animado que perceba, sinta, deseje, conceba, ou de algum modo, experimente algo.”(NEVES, 1997: 90).

4 Os critérios de transcrição adotados pelos pesquisadores responsáveis pelos projetos Filologia Bandeirante e Banco de dados do Português Popular falado na cidade de São Paulo não foram os mesmos, donde a não uniformidade gráfica dos trechos transcritos. 


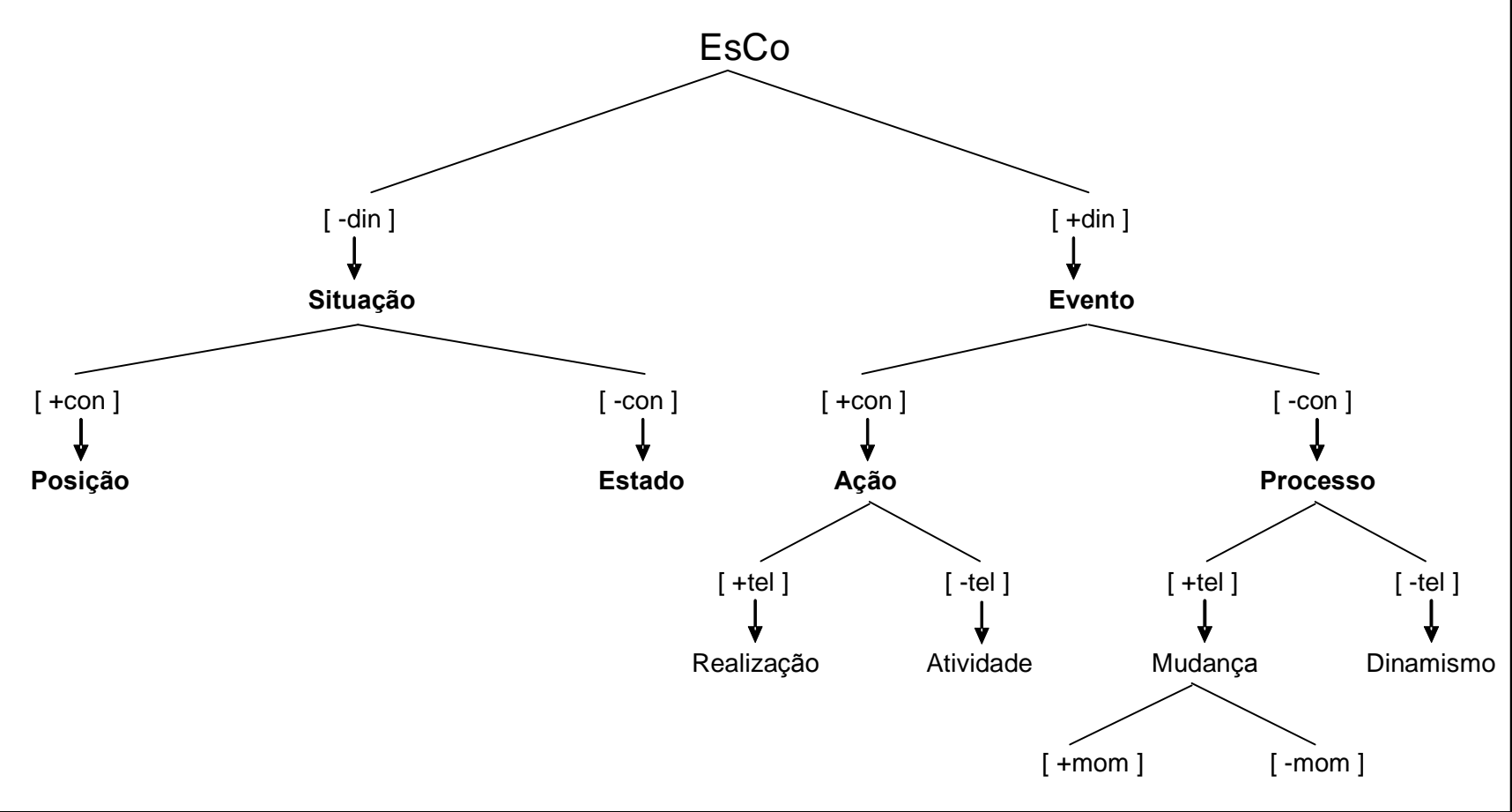

Quadro 5: Parâmetros semânticos para uma tipologia do EsCo. ${ }^{5}$

a) [-din] [+con] "eu moro aqui há vinte e cinco anos e eu gosto muito daqui...." (PP.Inq. XV: 3)

b) [-din] [-con] “.... essa casa aqui tá bonitinha... é piquinininha mais tá bem feitinha mais a minha... ”(PP. Inq. XV:635)

c) [+din] [+con] [+tel] “... veio um médico... ali na na sociedade... vinha um um médico sempre né... ”(PP. Ina. XV: 110)

d) [+din] [+con] [-tel] “...eu cuidava aqui da minina...ela me ela me pagava uns: :: me pagava cem” (PP. Inq. XIII:569)

e) [+din] [-con] [+tel] "foi um negócio esquisito lá... a árvore perto da casa caiu...foi aquele tropelo...”( FIL. Inq. V:45)

f) [+din] [-con] [-tel] “aqui em Bom Sucesso tremia tudo...essas pratelera aqui tremia tudo...só a garrafada...” (FIL. Inq. X:65)

g) [+din] [-con] [+tel] [+mom] “Ah ele nasceu e e crio aí depoi deu...doença neli e eli morreu... padre Zé .:” (FIL. Inq. II:33)

h) [+din] [-con] [+tel] [-mom] “ele foi adoeceno...ficano doente....até que um dia morreu....” (FIL. Inq. II:74) 
A predicação que está na estrutura subjacente da cláusula pode ser dividida em três níveis: Predicação Nuclear, Predicação Central e Predicação Estendida. Esta distinção é muito importante para este estudo, principalmente entre o primeiro e o terceiro nível, já que a predicação nuclear consiste na aplicação de algum predicado a um número apropriado de termos (argumentos) e a predicação estendida caracteriza-se por apresentar operadores de predicação e satélites de nível 2. A predicação central caracteriza-se por apresentar operadores e satélites de nível 1.

Os locativos podem ser ora argumentos ora satélites constituindo assim, uma Predicação Nuclear ou uma Predicação Estendida. Quando um locativo forma uma Predicação Nuclear, ele não pode ser retirado da oração, pois isto acarreta perda de sentido para a oração. $\mathrm{O}$ mesmo já não acontece quando o locativo forma junto com o predicado uma Predicação Estendida. Ele pode ser retirado sem nenhum prejuízo à sentença.

1. A Predicação Nuclear (nuclear predication) consiste na aplicação de algum predicado ao seu número apropriado de termos. É o predicado mais os seus argumentos.

(12) ... ai eu fui lá... realmente o Fernando tava com um monte de falta

(PP. Inq XII: 142)

(13) visto eu tê uma filha única ... de quarenta e sete anos... a minha filha... e o primero filho dela eu peguei pra mim e registrei como filho ... então ela mora em Recife e eu moro aqui... ele é casado... já o meu neto... ele é casado

(PP. Inq XV:154)

2. A Predicação Central (core predication) consiste na atribuição ao predicado de seus respectivos argumentos mais a inclusão de operadores de predicado de tempo e modo (perfectivo ou imperfectivo) e satélites de nível $1^{6}$, que indicam modo, velocidade e instrumento. ${ }^{7}$

(14) "Aí, aí eu tô cunversanu cu pessoal, aí chegô de mansinho uma colega minha na porta, né... e o colega tava lá na porta"

(PP. Inq.XIII:13)

\footnotetext{
${ }^{6}$ Para uma melhor distinção dos tipos de satélites ver 2.3 , p.44, desta dissertação.
}

${ }^{7}$ Pode ocorrer que a predicação nuclear e a predicação central sejam iguais, já que a manifestação da 
3. Por último, a Predicação Estendida (extended predication) consiste na atribuição à predicação central de operadores de predicação de tempo que localizam o EsCo no Passado, por exemplo, e satélites de nível 2.

(15) Universidade Paulista de Medecina, que trabalha aqui junto com a gente, ela tá fazendo um trabalho a cerca de dois a treis meses aqui com a gente, tem nos dado maior apoio, tem visto nossos problemas do dia-a-dia, né, na medida do possível dela tamem, né, e fazemos uma reuniãozinha, assim uma veis por meis, uma cada dois meses, na medida do nosso possivel pra tentá vê os nossos problemas do dia-a-dia aqui

(PP. Inq. XVI:85)

(16) os vendedores ambulantes apanhando, porque aqui tem vários vendedores ambulantes. Eu trabalho como segurança aqui faço um biquinho ali trabalho de servente lá, encanador elétrica

(PP. Inq. XVI:275)

(17) Qui aqui num tinha...é num muitu tinha carru aqui purque aqui num tinha esse asfalto...ah....agora feiz esse asfalto aqui cabô tudu

(FIL. Inq. III: 8)

A predicação estendida pode ser usada para construir uma estrutura proposicional que especifica um fato possível. Na Proposição são acrescentados os operadores por meio dos quais o falante especifica a atitude em relação ao conteúdo proposicional. Também neste nível, são acrescentados os satélites de nível 3, que nada mudam no EsCo, apenas restringem o valor que o falante confere ao conteúdo proposicional

Uma proposição estendida pode ser usada para a construção de uma Cláusula que simboliza um ato de fala. Neste nível, atuam os operadores de nível 4 (Declarativo, Interrogativo, Imperativo) e satélites de nível 4, que conferem a força ilocucionária necessária para que o falante consiga atingir sua estratégia comunicativa.

Ainda na estrutura subjacente da oração acontece a atribuição das funções sintáticas e pragmáticas.

As Funções Sintáticas de Sujeito e Objeto expressam a perspectiva que um falante apresenta para definir certo EsCo. As funções pragmáticas são atribuídas já no nível da cláusula. São as funções que especificam o caráter informativo dos constituintes dentro dos contextos comunicativos em que eles ocorrem. Elas dependem essencialmente de 
Com a atribuição das funções sintáticas e pragmáticas, a estrutura subjacente da oração, a predicação, fica completamente especificada e pronta para receber as regras de expressão. Tais regras determinam como as estruturas funcionais serão representadas na estrutura morfo-sintática das expressões lingüísticas. Enfim, as regras de expressão tratam da ordem, forma e do padrão de entoação dos constituintes da estrutura subjacente da oração.

Para nosso estudo interessam as regras de expressão que são responsáveis pela ordenação, já que é interessante observar a posição que os locativos ocupam quando exercem a função de argumento e quando são satélites de nível 2.

As regras de expressão que são responsáveis pela ordenação dos constituintes são intituladas de regras de colocação. Tais regras são responsáveis por conferir posições aos constituintes da estrutura subjacente na seqüência linear em que eles podem ser atualizados, dado seu estatuto na estrutura subjacente.

Segundo Dik (1989), as regras de colocação devem ser consideradas como parte do componente de expressão da GF, isto é, a ordem dos constituintes serve como um dos meios através dos quais relações e funções da estrutura subjacente podem ser formalmente expressas. Considerar regras de colocação como um mecanismo de expressão equivale a postular teoricamente a funcionalidade da ordenação de constituintes, de modo que ordens alternativas podem expressar certas distinções nas estruturas subjacentes.

As regras de colocação designam uma posição a constituintes que não dispõem ainda de lugar, organizando linearmente estruturas subjacentes não ordenadas.

A teoria da ordenação dos constituintes na GF assume que as línguas apresentam um ou mais padrões funcionais, conforme o esquema abaixo:

\section{(18) P2, P1 (V) S (V) O (V) X, P3}

$\mathrm{Na}$ representação, P2 e P3 indicam posições reservadas aos constituintes extraoracionais, como o Tema que ocupa a posição P2 e o Antitema que ocupa a posição P3, e entre as vírgulas, encontram-se os possíveis padrões para a oração propriamente dita, que constitui uma predicação completa, conforme o esquema Tema, Predicação,

\section{Antitema.}

Pezatti (1997) explica 
as regras de colocação determinam, em primeiro lugar, que constituintes devem ou podem ir para a posição $\mathrm{P} 1$ : verifica-se, primeiramente, se há algum constituinte-P1 na predicação, como palavras-Qu, pronomes relativos e conectores subordinadores. Se nenhum constituinte desse tipo estiver presente, então, podem ser colocados na posição P1 constituintes com função de Foco ou de Tópico. Aplicadas as regras de $\mathrm{P} 1$, todos os demais constituintes da predicação assumem as respectivas posições estruturais, indicadas por $\mathrm{S}, \mathrm{O}, \mathrm{V}$ e outros símbolos possíveis, como $\mathrm{X}$, usados especialmente para indicar posições de satélites.

Se não houver na oração constituintes passíveis de ocuparem a posição $\mathrm{P} 1$, como mencionado acima, então, podem ser colocados em P1 constituintes com as funções pragmáticas de Foco (informação de maior saliência), Tópico (sobre o que se fala) ou Organizador de Cenário (situa o EsCo em relação às coordenadas de tempo, espaço e circunstância). Dessa maneira, um satélite de nível 2 pode exercer a função pragmática de Organizador de Cenário, responsável por situar o EsCo no quadro espacial (de lugar) dos interlocutores, como mostram os exemplos abaixo.

(19) Lá no hospital na Santa Casa eles dava medicação... era tudo dia tumano medicação... ia de manhã ... passava a tarde... passava o dia... e vinha quatro hora

(PP. Inq. XIV: 103)

(20) ela custumô... agora ela num quer ir mais pra lá...num qué mais voltá pra lá mais não... aí tem o seguinte... eu tenho mais cunformado aqui do que lá... lá eu num tinha cunvivência ... lá eu num passei um dia cum dívida, tinha um dia que acordava, tinha um dia que num tinha ...e ia o dia todinho

(PP. Inq. XVI:157)

(21) (lá em) () lá di noite vamo buscá água di noiti tudos nóis as muierada as moçaiada tudu buscá água carregá água limpinha pa fazê café pu pessoar qui tava: :: aguardandu tudu né? pa i embora né?

(FIL. Inq. I: 8)

Com isso, vemos que a GF de Dik dá conta da estrutura da sentença, desde a representação semântica subjacente até a forma fonética de superfície e, assim, “apresenta um quadro para a descrição científica da organização lingüística em termos 
das necessidades pragmáticas da interação verbal, na medida em que isso é possível.’(GEBRUERS, 1984, apud NEVES, 1997:98.).

\subsection{A SOCIOLINGÜÍSTICA VARIACIONISTA}

Embora nosso estudo não seja um trabalho variacionista prototípico, alguns procedimentos metodológicos da Sociolingüística Variacionista são de grande importância para nosso trabalho tais como as noções de quantificação e correlação.

Fernández (1997:307) ensina que

a sociolingüística variacionista, chamada também variacionismo, e que teve como uma de suas preocupações iniciais o estudo da língua em seu contexto social, e mais que isso, o estudo da língua falada nos grandes centros urbanos, nasceu nos anos $60 \mathrm{em}$ torno da figura de Labov, ainda que seu desenvolvimento posterior se tenha devido aos trabalhos desenvolvidos na Filadélfia e no Canadá. Esta sociolingüística tem entre seus objetivos descobrir a ordem que possa haver na variação e na mudança lingüística. Para cumprir tal objetivo, quando os dados se contam por centenas, recorre-se à quantificação, porque a importância das análises qualitativas, que ninguém nega, é paralela ao interesse dos estudos quantitativos: não se pode contar o que não seja identificado.

Ou seja, o pesquisador deve contar seus dados correlacionando-os a determinadas variáveis já pré-estabelecidas. Assim, em nosso trabalho dá-se a quantificação e estabelece-se correlação entre dados e fatores ou variáveis independentes pertinentes ao nosso estudo.

Faz-se ainda necessário esclarecer algumas outras noções para que possamos apresentar de maneira clara como utilizaremos a Sociolingüística Variacionista em nosso trabalho.

As formas em variação recebem o nome de "variantes lingüísticas". Labov (apud TARALLO, 1985:08) afirma que "variantes lingüísticas são diversas maneiras de se dizer a mesma coisa em um mesmo contexto e com o mesmo valor de verdade. A um conjunto de variantes dá-se o nome de variável lingüística". Essas variáveis subdividem-se em variáveis dependentes e independentes. A variável dependente é o fenômeno que se objetiva estudar; no caso presente, por exemplo, quando os locativos 
são os fatores lingüísticos (estruturais) ou sociais (extralingüísticos). Em nosso trabalho, constituem as variáveis independentes: tipo de EsCo, ordem, troca de posição e tipo de texto.

Vemos assim, que não estamos trabalhando com um caso de variação típico em nosso estudo, uma vez que não observamos formas em coocorrência ou em concorrência, e também não nos valemos de fatores sociais em nossa análise, somente analisamos a possibilidade de correlacionar a função Argumento e Satélite a algumas condições de produção. Assim valemo-nos de uma estratégia da Sociolingüística Variacionista:

para o estabelecimento de correlações entre variáveis ou fatores de diferente natureza o procedimento continua a ser utilizado, ou seja, as dificuldades e controvérsias teóricas não impedem que se siga fazendo correlações entre uso e condições de uso e análises estatísticas, com mais força e qualidade que nunca, mas considerados como ferramenta descritiva da variação.(RODRIGUES,2005)

Dessa maneira, nossa tarefa será correlacionar as variáveis independentes apontadas acima para verificarmos os contextos de uso dos locativos. Ou seja, veremos a probabilidade de um locativo ser um argumento ou satélite na oração estabelecendo correlações entre as ocorrências e os grupos de fatores.

Para a Quantificação dos dados, a Sociolingüística Variacionista trabalha com dois tipos de estatísticas: uma estatística descritiva e uma estatística de inferências.

A estatística descritiva inclui provas simples de quantificação, muito conhecidas, como o cálculo de freqüências absolutas, sua conversão em freqüências relativas e o cálculo de médias, variâncias e desvios típicos. Já a estatística de inferência pertence ao campo das análises multivariáveis. Este tipo de inferência permite chegar a conclusões sobre a variação lingüística em uma comunidade, partindo da análise dos dados recolhidos em uns poucos falantes que são considerados representativos dessa comunidade.

Dessa forma, a Sociolingüística Variacionista contribui para nosso estudo na medida em que trabalhamos com o estudo da língua em contexto social, com quantificação de dados e com noções de correlação, que permitem associar o uso às condições de produção. 


\section{CAPÍTULO 2}

\section{OS LOCATIVOS ADVERBIAIS NO PORTUGUÊS}

\subsection{OS ADVÉRBIOS NA GRAMÁTICA TRADICIONAL}

Este estudo tem por objetivo entender e contribuir para um melhor entendimento da classe e das funções que os advérbios (Adv), mais precisamente os advérbios locativos aqui, aí, ali e lá, exercem na oração. Para isso foi preciso ter uma noção de como este assunto é abordado nos compêndios gramaticais tradicionais e de como ele é entendido pelos lingüistas em estudos mais recentes. O propósito desse paralelo inicial é estabelecer um diálogo entre o viés dos gramáticos e dos lingüistas, de maneira a ir criando uma tessitura dos estudos já existentes sobre os advérbios.

A primeira ressalva a ser feita ao leitor é que não estabelecemos aqui diferença entre advérbio e locução adverbial, na medida em que "O advérbio é a categoria nuclear do Sintagma Adverbial, podendo apresentar-se como uma única palavra ou como uma locução adverbial” (MIRA MATEUS, 1989:207).

Comentamos também a redundância presente na maioria dos compêndios gramaticais, sendo poucos os que conseguem acrescentar informações novas sobre esse assunto. Vale ainda ressaltar certa titubeação na apresentação dos advérbios, ora encontrados todos dentro de uma mesma classe gramatical, ora junto com pronomes devido à natureza distinta de alguns advérbios, ou ainda em contraste com adjetivos. Sob o ponto de vista sintático, algumas das Gramáticas Tradicionais (GT) consideram-nos, em alguns momentos, termos acessórios da oração, porém outras como Luft (1994), Rocha Lima (1992), Kury (1991) e Bechara (2001) mais próximas de estudos lingüísticos mais recentes já apontam para uma possível função de complemento do verbo.

Parece haver uma imprecisão generalizada presente na classificação que as gramáticas tradicionais propõem e isto não se limita à categoria adverbial. Confirmam-se as palavras de Mattoso Câmara (1954:156 apud NÓBREGA, 2000) que explica: “a tradicional classificação dos vocábulos, que, pautada em critérios heterogêneos, confusos e sem hierarquia entre si, nos foi legada pela gramática greco-alexandrina e que apareceu, pela primeira vez, sob forma didática no manual de Dionísio da Trácia (120 $\mathrm{aC}) "$ 
Cientes de como são feitas as análises, vejamos o que alguns autores falam sobre os advérbios de lugar em questão.

Destacamos inicialmente Said Ali (1964), que é enfático quando afirma que os advérbios aqui, cá, lá, aí e ali devem ser considerados como pronominais, pois originam-se de pronomes demonstrativos do latim. Esclarece:

Originaram-se os nossos advérbios aqui, cá e lá das formas ablativas hic, hac do pronome demonstrativo latino aglutinadas a outras palavras (eccu(m)), ill(e). Aí, outrora hi ou i ainda que pareça filiar-se a ibi, é provavelmente o próprio vocábulo hi(c) com função adverbial. Ali procede de illic. Poderíamos, pois, atendendo à etimologia, classificar as formas portuguesas como advérbios pronominais." (p.184)

O autor explica que os advérbios denotam uma circunstância de lugar, tempo, modo, grau ou intensidade e servem de determinante do verbo, do adjetivo ou de outro advérbio.

$\mathrm{Na}$ oração pode exercer a função ora de termo acessório como adjunto adverbial, ora de complemento como objeto indireto circunstancial. Este último completa o sentido de verbos intransitivos, ou seja, aqueles que não admitem acusativo ${ }^{8}$, e têm semelhança com as circunstâncias expressas pelos advérbios.

Back \& Mattos (1972) observam que na oração tanto as locuções adverbiais como locuções substantivas podem exercer a função de complemento ablativo. Porém tal complemento pode ser ora obrigatório, ora facultativo. É o predicado que determina o seu grau de importância para a oração.

Esse complemento pode ser substituído por um dos advérbios de lugar aqui, ali, fora, dentro, onde, longe, perto, cá, lá e aí.

Para facilitar a compreensão do que cada autor propõe sobre os advérbios, optou-se por montar um quadro resumo separando categorização e função dos advérbios de acordo com cada autor estudado.

A definição de Macambira (1974) não se aproxima da definição clássica presente nas gramáticas escolares e distancia-se da normatividade. Ele define advérbio como uma palavra invariável que modifica o verbo, o adjetivo, o pronome, o numeral e o próprio

${ }^{8}$ De acordo com o autor, o termo que integra o sentido do verbo transitivo tem o nome de objeto direto ou pdfMachine A pdf writer that produces quality PDF files with ease!

Produce quality PDF files in seconds and preserve the integrity of your original documents. Compatible across nearly all Windows platforms, simply open the document you want to convert, click "print", select the "Broadgun pdfMachine printer" and that's it! Get yours now! 
advérbio. O autor afirma que o advérbio é indefinível sob o aspecto semântico, pois dizer que o advérbio exprime uma qualidade ou circunstância não é válido, uma vez que qualidade compete igualmente ao substantivo e ao adjetivo e circunstância é uma palavra vaga. É necessário definir com precisão o rótulo circunstância para se definir advérbio.

Para ele, os advérbios estão divididos em Nominais e Pronominais. Os nominais são aqueles que podem ser transformados em substantivo sem pronome. Exemplo:

(27) Grosseiramente = com grosseria .

Já os Pronominais são aqueles que se desdobram em substantivo com pronome. Exemplo o advérbio demonstrativo aqui = neste lugar.

Segundo o autor, os advérbios pronominais podem ser ainda reconhecidos quando respondem a perguntas como Onde? Quando?

O mesmo artifício das perguntas vale também para o adjunto adverbial que é considerado um termo acessório na oração. Ora, se o critério para se encontrar um adjunto adverbial na oração é a resposta a algumas perguntas, vemos que o autor não considera as expressões locativas como possíveis complementos de verbo, pois no exemplo:

(28) Moro na capital. / Moro aqui.

ao se fazer a pergunta Onde eu moro? A resposta é Na capital/aqui, logo tal termo é um adjunto adverbial de lugar. Dessa maneira, a classificação não procede.

O autor divide as circunstâncias em três classes: circunstâncias adverbiadas, preposicionadas e conjuncionadas.

Destas três, interessa a circunstância adverbial de lugar que foi considerada pelo autor como aquelas expressas por palavras ou expressões que respondem à pergunta onde? e suas combinações.

Kury (1991) admite que haja verbos transitivos adverbiais. Tradicionalmente tais verbos são classificados como intransitivos, mas se entendermos a transitividade como a necessidade de um complemento, verbos como chegar, ir, partir, seguir, vir, voltar, estar, ficar, morar quando pedem um complemento adverbial de lugar terão de ser vistos como transitivos; logo, os adjuntos adverbiais de lugar assumirão o posto de argumentos 
informações acessórias. Ou seja, o complemento adverbial de lugar, que pode ser expresso por um advérbio, locução ou expressão adverbial, é o termo de valor circunstancial que completa a predicação de um verbo transitivo adverbial, como podemos ver nos exemplos a seguir:

(24) “() quando cheguei lá ela já tava na sala de operação i eu... a cama no meio da sala"

(FIL. Inq. VII: 5)

(25) "() ela casô e foi embora aí o menino meu foi lá () ela chamava Maria do Socorro..."

(FIL. Inq. VII: 4)

Já o adjunto adverbial, também representado por advérbios ou locuções adverbiais, acrescenta circunstâncias a verbos ou intensificam a idéia expressa por um verbo, adjetivo ou outro advérbio.

(26) Ah:: muito pouco estudei quatro ano aqui no caqui

(FIL. Inq. VII: 46)

Rocha Lima (1992:252) também considera as expressões de natureza adverbial como possíveis complementos circunstanciais que são "tão indispensáveis à construção do verbo quanto em outros casos, os demais complementos verbais". Esses complementos acompanham os chamados verbos transitivos circunstanciais. Para ele a diferença entre complemento e adjunto está na relação que o verbo estabelece com a preposição. Assim, se a regência do verbo pede uma preposição que possa acompanhar um locativo, logo este locativo será um complemento do verbo. Por exemplo:

(23) “ : então a genti: : eu vô pra lá um dia eu falei assim pa minha irmã assim "ói nóis vamo lá na roça"

(FIL. Inq. IX: 71)

Explica o autor que "por seu valor de verbo de direção, ir exige, por assim dizer, uma preposição para ligá-lo ao termo locativo.” (p.252). Notamos que quando o autor 
vale-se da expressão verbo de direção demonstra, dessa forma, uma preocupação semântica quanto à classificação dos advérbios locativos.

Para ele é válida a inclusão dos locativos entre os complementos verbais, o que mostra um complemento circunstancial, porém a distinção entre complemento e adjunto adverbial não ficou muito clara em sua obra.

Luft (1994:136) ensina que o advérbio é uma "palavra de natureza (1) nominal (depressa < de pressa; apenas < a penas; claro, claramente; bem/mal, cp. bom/mau) ou (2) pronominal (aqui, aí, ali), que se acrescenta à significação: a) de um verbo, b) de um adjetivo, ou de um outro advérbio, ou c) de toda uma frase." Essas palavras apontam para a polimorfia desta grande classe de palavras.

O autor utiliza critérios semânticos e sintáticos para mostrar as diferenças entre os advérbios. Para ele, os advérbios podem ser classificados em Nominais e Pronominais. Os advérbios de lugar aqui, aí, ali e lá estariam entre os pronominais demonstrativos, uma vez que substituem expressões como neste lugar, nesse lugar, naquele lugar.

O autor observa ainda que os advérbios de lugar constituem um tipo de complemento verbal, que ele chama de complemento (indireto) locativo, e não podem ser apenas considerados como adjuntos adverbiais.

Percebemos, desta forma, que o autor preocupou-se em não colocar sob o mesmo rótulo todos os advérbios, já que se trata de uma classe heterogênea e eles não exercem as mesmas funções sintáticas. Assim em uma oração como:

(22) “... i meus irmão nu morava aqui meus irmão morava lá nu novu osasco...não... ali pertu di cotia..."

(FIL. Inq. I: 696)

as expressões aqui e lá não poderiam ser consideradas adjuntos, pois são exigidas pela semântica do verbo morar. Vemos aí que o autor não somente se preocupou com a sintaxe, mas também fez referência à semântica.

Perini (1996:340) afirma que a classificação que as gramáticas tradicionais trazem sobre o assunto é insuficiente, já que apresentam o advérbio como termo que "modifica" determinadas classes. Para ele "as diferenças sintáticas entre os advérbios são muito profundas em parte comuns a palavras de outras classes tradicionais, e não autorizam a postulação de uma classe única. Temos, aqui, na verdade, diversas classes, que podem 
sem dúvida agrupar-se, mas dificilmente de maneira análoga à proposta pela análise tradicional.”.

O autor vale-se de critérios sintáticos e afirma que o adjunto adverbial só compreende uma pequena parte dos termos tradicionalmente chamados "adjuntos adverbiais". Ele admite existir adjunto adverbial, adjunto oracional e adjunto circunstancial. Nesta análise, somente o último poderia ter uma função relevante na oração. Entenda-se por função relevante aquelas que são exigidas ou recusadas por algum verbo. Assim, os adjuntos circunstanciais teriam função de "complemento" como o objeto direto, complemento do predicado e predicativo.

O autor afirma que uma classificação suficiente desta classe só pode ser feita em termos de funções deste advérbio, já que "sob o rótulo de "advérbio" se esconde uma variedade irredutível de classes." (PERINI 1996:342).

Em Cunha \& Cintra (2001) não notamos uma preocupação por diferenciar os advérbios com base em um critério sintático-semântico. Ainda que o autor afirme, em nota, que sob a denominação de ADVÉRBIOS reúnem-se, numa classe heterogênea, palavras de natureza nominal e pronominal com distribuição e funções às vezes muito diversas, ele não estabelece uma classificação desse tipo.

Sob o ponto de vista sintático, os advérbios são adjuntos adverbiais, termos acessórios que se juntam a um nome, a um adjetivo, a um advérbio ou a um verbo para precisar-lhes o significado, acrescentam informações que podem ser dispensáveis. Nesse sentido, não considera em nenhum momento advérbios ou locuções adverbiais locativas como possíveis argumentos de uma oração.

Bechara (2001) não tem o mesmo posicionamento que Cunha \& Cintra (2001). O autor afirma que os advérbios pertencem a uma classe heterogênea que apresenta grande mobilidade semântica e funcional e, devido a isso, há uma grande dificuldade em se obter uma classificação uniforme e coerente.

Quando classificados a partir de critérios léxicos, os locativos irão aparecer como denotadores de lugar e quando vistos sob um critério funcional serão entendidos como demonstrativos.

O autor também admite que os advérbios apresentem uma natureza distinta, são de origem nominal e pronominal e que se referem ao verbo, ao adjetivo, advérbio ou a toda a oração.

O advérbio, segundo Bechara (2001), é uma expressão modificadora que por si só 
adverbial. É interessante notar que o autor não vê todos os advérbios com esta função, uma vez que ele admite haver expressões adverbiais que podem ser argumentos de verbo. Para tais expressões ele dá o nome de complemento relativo. Ele explica

O predicado complexo também pode conter verbo cujo conteúdo léxico é de grande extensão semântica, que exige outro tipo de signo léxico que delimite e especifique a experiência comunicada, à semelhança do complemento direto. A diferença é que neste segundo caso o determinante do predicado complexo vem introduzido por preposição; a tal termo chamamos complemento relativo. (p.419).

Incluem-se como complementos relativos os argumentos dos verbos ditos locativos, situativos e direcionais, o que permite sua comutação com advérbios de equivalência semântica.

No exemplo:

(29) A criança caiu da cama durante a noite. I A criança caiu de lá durante a noite.

podemos observar que a expressão da cama pertence à regência do verbo e se a retirarmos, a oração ficará sintática e semanticamente incompleta, logo temos aí um complemento relativo. Isso não se aplica ao termo durante a noite que pode ser entendido como adjunto adverbial, já que pode ser retirado sem danos ao entendimento da oração. Dik (1989) também pensa dessa maneira e propõe o mesmo teste para se descobrir se um advérbio é satélite ou argumento. (Cf. em 2.3, p.46)

Em nota, Bechara (2001) afirma que ainda não há unanimidade entre os estudiosos em considerar tais argumentos do predicado complexo como sendo complementos. 


\begin{tabular}{|c|c|c|}
\hline & CATEGORIZAÇÃO & FUNÇÃO \\
\hline SAID ALI (1964) & $\begin{array}{l}\text { Nominais e Pronominais. Denotam } \\
\text { circunstância de lugar, tempo, } \\
\text { modo, grau ou intensidade e serve } \\
\text { de determinante do verbo, do } \\
\text { adjetivo ou de outro advérbio. }\end{array}$ & $\begin{array}{l}\text { Os advérbios de lugar podem ser } \\
\text { adjuntos adverbiais ou complementos. } \\
\text { Quando complementos recebem o nome } \\
\text { de objeto indireto circunstancial. }\end{array}$ \\
\hline $\begin{array}{l}\text { BACK \& } \\
\text { MATTOS (1972) }\end{array}$ & & $\begin{array}{l}\text { Os advérbios de lugar recebem o nome } \\
\text { de complemento ablativo que pode ser } \\
\text { ora obrigatório, ora facultativo. É o } \\
\text { predicado que determina. }\end{array}$ \\
\hline $\begin{array}{l}\text { MACAMBIRA } \\
\text { (1974) }\end{array}$ & $\begin{array}{l}\text { Palavra invariável que modifica o } \\
\text { verbo, o adjetivo, o pronome, o } \\
\text { numeral, o próprio advérbio. Divide } \\
\text { os advérbios em Nominais e } \\
\text { Pronominais. }\end{array}$ & $\begin{array}{l}\text { Os advérbios de lugar são termos } \\
\text { acessórios, são adjuntos adverbiais. }\end{array}$ \\
\hline KURY (1991) & $\begin{array}{l}\text { Os advérbios intensificam a idéia } \\
\text { expressa por um verbo, adjetivo ou } \\
\text { outro advérbio. }\end{array}$ & $\begin{array}{l}\text { Os advérbios de lugar podem ser } \\
\text { complementos. Recebem o nome de } \\
\text { complemento adverbial. }\end{array}$ \\
\hline $\begin{array}{l}\text { ROCHA LIMA } \\
\text { (1992) }\end{array}$ & & $\begin{array}{l}\text { Os advérbios de lugar podem ser } \\
\text { complementos. Neste caso, recebem o } \\
\text { nome de complementos circunstanciais. }\end{array}$ \\
\hline LUFT (1994) & $\begin{array}{l}\text { Classifica os advérbios em } \\
\text { Nominais e Pronominais. }\end{array}$ & $\begin{array}{l}\text { Os advérbios de lugar podem ter a } \\
\text { função de complemento verbal. } \\
\text { Recebem o nome de complemento } \\
\text { indireto locativo. }\end{array}$ \\
\hline PERINI (1996) & & $\begin{array}{l}\text { Os advérbios de lugar podem ser } \\
\text { adjuntos circunstanciais com função de } \\
\text { complemento. }\end{array}$ \\
\hline $\begin{array}{l}\text { CUNHA \& } \\
\text { CINTRA (2001) }\end{array}$ & & $\begin{array}{l}\text { Entende os advérbios de lugar como } \\
\text { adjuntos adverbiais. }\end{array}$ \\
\hline $\begin{array}{l}\text { BECHARA } \\
(2001)\end{array}$ & $\begin{array}{l}\text { Origem Nominal e Pronominal e se } \\
\text { referem ao verbo, ao adjetivo, } \\
\text { advérbio ou toda a oração. }\end{array}$ & $\begin{array}{l}\text { Os advérbios de lugar podem ser } \\
\text { complementos. Recebem o nome de } \\
\text { complemento relativo dos verbos ditos } \\
\text { locativos, situativos e direcionais. }\end{array}$ \\
\hline
\end{tabular}

Quadro 6: Quadro resumo sobre categorização e função dos advérbios de acordo com alguns gramáticos. 
Parece difícil encontrar facilidades e certezas quando se analisam os Advs. A mais elementar definição presente em algumas das GTs estudadas - modificador de um verbo, um adjetivo ou outro advérbio - não considera que o Adv possa modificar toda uma oração. No entanto, apesar da nomenclatura variada, alguns autores falam de duas funções sintáticas distintas - adjunto e complemento, que é também o ponto de vista adotado nesta dissertação.

\subsection{ABORDAGEM DOS LINGÜISTAS}

A língua portuguesa, segundo Mattoso Câmara (1975:110), tem em princípio três tipos básicos de advérbios, dois deles pronominais e um nominal. Os pronominais são divididos em locativos e temporais e destinam-se a situar o evento comunicativo no espaço e no tempo em relação à posição espacial e temporal do falante. O nominal, por sua vez, apresenta os modos de ser do evento. O autor explica que "é aos advérbios modais que se refere a tradicional definição de advérbio como palavra que modifica o verbo, um adjetivo ou outro advérbio".

Em outra obra (MATTOSO CÂMARA, 2002), o autor afirma existir em português quatro tipos de complemento. São eles: complementos objetivos, circunstanciais, predicativos e de agente ou causa eficiente.

Os complementos circunstanciais são aqueles que ampliam a comunicação lingüística feita pelo predicado indicando variadas circunstâncias como de modo, lugar e tempo. Essas circunstâncias podem ser substituídas por advérbios correspondentes como em:

(30) Vou à praia todos os dias. / Vou lá cotidianamente.

"Daí o nome de adjuntos adverbiais, que se dá aos complementos circunstanciais onde o termo adjunto é adotado para insistir no caráter acessório que se lhes atribui na comunicação, mas nem sempre exato.” (MATTOSO CÂMARA, 2002:73). Como podemos notar o verbo ir pressupõe necessariamente um ponto de chegada como complemento circunstancial de lugar, razão pela qual o termo acessório não se aplicaria a essas expressões locativas.

Mira Mateus et al. (1989) entendem os advérbios como pertencentes a um 
elas os SADVs complementos estão colocados à direita do núcleo do SV e têm função sintática de oblíquos. Qualquer argumento de um predicado a que não seja atribuída nenhuma das funções sintáticas centrais, são elas sujeito, objeto direto, objeto indireto e predicativo, têm a função de oblíquo, que para as autoras, são em geral argumentos ${ }^{9}$ opcionais.

De acordo com esta abordagem, os advérbios podem ser argumentos nucleares, ou seja, exigidos pelo predicador, ou argumentos opcionais que o predicador admite, mas não exige. Nos dois casos os locativos adverbiais teriam a função sintática de oblíquo.

O tipo de propriedade ou relação expressa pelo predicador define as relações que com ele mantêm os seus argumentos nucleares. As autoras chamam de função semântica desse argumento à relação que cada argumento nuclear mantém com o seu predicador.

Assim, a função semântica do argumento que exprime a localização de uma dada entidade seria a Função semântica Locativa. Há uma distinção entre um locativo situacional (L sit), característico dos Predicadores de Estado (Pe), e um Locativo direcional ( $\mathrm{L}$ dir), característico dos Predicadores de processo (P pro) e de evento (P ev).

Ex: (31) O Luís mora (Pe) em Paris.(L sit) /O Luís mora(Pe) aqui.(L sit).

(32) O Luís partiu (Pev) para Paris. (L dir) / O Luís partiu(Pev) para lá.(L dir)

Nos dois exemplos o Locativo é um argumento com a função sintática de oblíquo, pois localiza o estado de coisas descrito no espaço.

Bomfim (1988), a partir de definições de advérbios dadas pelas gramáticas tradicionais, questiona a inclusão de determinadas expressões nessa classe e conclui que não existe correspondência entre a conceituação de advérbio e o comportamento lingüístico dos componentes da classe.

A autora começa pela definição de que o advérbio se junta a verbos para exprimir circunstâncias. Por meio de seus estudos, pode-se perceber que nem todos os advérbios juntam-se a verbos, como já foi visto em Mattoso Câmara (1975). A autora explica que esta é uma característica quase que exclusiva dos advérbios de modo, ou nominais. No que concerne à expressão de circunstância, muitos advérbios respondem às perguntas

${ }^{9}$ Deve-se observar que as autoras atribuem o nome de argumento tanto a locativos que são pedidos pela pdfMachine A pdf writer that produces quality PDF files with ease!

Produce quality PDF files in seconds and preserve the integrity of your original documents. Compatible across nearly all Windows platforms, simply open the document you want to convert, click "print", select the "Broadgun pdfMachine printer" and that's it! Get yours now! 
onde? e quando?(um dos meios utilizados por algumas gramáticas para a classificação dos advérbios) mas os advérbios de lugar (aqui, aí, ali, lá) e alguns de tempo (ontem, hoje, amanhã) possuem características que os fazem pertencer mais à classe dos pronomes do que à classe dos advérbios propriamente ditos.

Isto é reforçado pela organização que a autora traçou das características dos chamados advérbios de lugar levando-se em consideração aspectos sintáticos e semânticos.

As características apontadas por Bomfim (1988) referentes aos locativos aqui, aí, ali e lá, são as que seguem. Tais termos:

- não são passíveis de intensificação;

- coocorrem com outros indicadores de lugar;

- localizam no espaço o processo verbal e/ou o elemento que cabe localizar;

- são dêiticos;

- podem exercer a função de sujeito;

- não se juntam a preposições para formar locuções, mas podem ser precedidos de preposição;

- respondem satisfatoriamente à pergunta onde?

Estas características reforçam a idéia de que tais expressões devem compor a classe dos pronomes e não dos advérbios.

Bomfim (1988) afirma, quanto às características dos locativos, que eles são apenas dêiticos. A autora também chama atenção para um impasse quanto à definição proposta por algumas das gramáticas tradicionais.

Se os considerarmos advérbios, temos de reformular a conceituação da classe. Os chamados adjuntos adverbiais preenchem em melhores condições o requisito da expressão de circunstância. Não são, entretanto, advérbios nem tampouco locuções adverbiais. Admiti-lo seria confundir função com classe. (p.66).

A autora conclui que os advérbios que se juntam ao verbo são propriamente os modais, como sugere Mattoso Câmara. Ela não admite que os locativos adverbiais possam exercer função de complemento ${ }^{10}$, pois estes não podem ser considerados advérbios, mas sim pronomes, devido às características apresentadas acima. Ou seja, no 
fundo os locativos aqui, aí, ali e lá podem ser complementos na oração, mas não devem ser chamados de advérbios.

Sobre a questão semântica dos advérbios de lugar, Pontes (1992) procura estabelecer traços que distingam os advérbios entre si. Trabalha com os advérbios (pro) de lugar aqui, aí, ali e lá. Para ela, tais advérbios são "pro”, pois constituem sozinhos um sintagma, não ocorrem acompanhados de um SN como outros advérbios. Podemos entender tais advérbios como os intransitivos, não-completáveis ou avalentes de Neves (2000). (Cf.p.41)

A autora leva em conta os traços pessoa e distância para a descrição destes advérbios. A partir da situação de comunicação em que estão envolvidos o falante e o ouvinte, pode-se estabelecer um quadro das relações semânticas que vigoram entre esses quatro advérbios. Assim:

\section{DISTÂNCIA}

\begin{tabular}{|c|c|c|c|}
\cline { 2 - 4 } \multicolumn{1}{|c|}{ PESSOA } & 1 & 2 & 3 \\
\hline 1 & aqui & & \\
\hline 2 & aí & & lá \\
\hline 3 & & ali & \multicolumn{2}{|c|}{ Quadro 7: Relações semânticas entre os locativos. } \\
\hline
\end{tabular}

PONTES (1992:15) explica o quadro da seguinte forma:

Aqui e aí se opõem por um traço de pessoa $\left(1^{\circ} \mathrm{X} 2^{\circ}\right)$, exclusivamente. Já a sua oposição a ali aparece mais claramente como de distância, a de pessoa sendo menos óbvia. Pode-se afirmar apenas que não é nem $1^{\circ}$ nem $2^{\circ}$ e por esta razão chamá-la de $3^{\circ}$. Mas isso não significa que ali indique que o objeto esteja próximo de uma pessoa, como acontece com outros advérbios (aqui e aí). Com lá acontece o mesmo que com ali em relação a pessoa: indica distância da situação de comunicação e difere de ali em grau de distância.

Ilari et al. (1991:78) discutem os limites imprecisos da classe dos advérbios levando em conta os critérios morfológico, sintático e nocional propostos pela gramática tradicional (GT) e concluindo que os critérios utilizados por ela "para delimitar a classe dos advérbios não identificam, nem mesmo aproximativamente, as expressões que a mesma tradição gramatical tem apontado como advérbios; por conseguinte, os critérios 
tradicionais não são imediatamente aproveitáveis para uma análise rigorosa". Ou seja, a gramática tradicional agrupa sob um mesmo rótulo itens que não atendem aos critérios tradicionais e, no entanto são bastante produtivos na língua falada.

O autor diz que os chamados advérbios circunstanciais possuem uma série de empregos que transgridem a classificação tradicional de advérbio. Segundo Ilari, os dêiticos possuem propriedades sintáticas e distribucionais próprias que os distinguem dos outros "advérbios". Para ele, os dêiticos invariáveis a que se têm chamado tradicionalmente de "advérbios de lugar/ advérbios de tempo" admitem usos bastante variados e comportam empregos altamente diferenciados como argumentos de verbo ou como operadores textuais.

Ilari (1991) afirma que os locativos aqui, aí, lá e ali, são elementos dêiticos e, dessa forma, podem assumir função argumental, bem como o termo aí, que em alguns momentos, tem função de conector de texto, como no exemplo a seguir extraído de um inquérito que é parte integrante deste estudo.

(33) ...e eu era muito ruim pra trocá o dinhero ...e.: ruim memo...aí eu falava e mãe eu num gostu desse negócio só por causa trocá os cobre...ela falava não mais o povo depois pagava né?...aí trazia nessa rua aqui eu truxe muito trouxe muita broa de queijo...

Percebe-se que a posição em início de frase do advérbio ai faz com que ele, em alguns casos, perca sua função dêitica de locativo e assuma um valor de conector textual, podendo também operar no interior de uma unidade discursiva.

Devido a esses fatos, Ilari (1991) excluiu os dêiticos e os advérbios de coesão textual de seu trabalho e analisou os advérbios em uma matriz de duas entradas: "uma dessas entradas classifica essas ocorrências pela sua função, a começar pela distinção predicativo/não-predicativo; a outra classifica-os pelo tipo de unidade sintática a que se aplicam, a começar pela distinção entre advérbios sentenciais e de constituinte." (p.93)

A primeira entrada pode ser vista como uma entrada semântica, pois implica reconhecer que os advérbios desempenham dois papéis semânticos, o da predicação (ou modificação), em que dá uma contribuição ao sentido da classe alvo, e o da não predicação, em que essa contribuição não ocorre. Foram propostos como advérbios 
aspectualizadores. Como não-predicativos, os de verificação (afirmação, negação, Inclusão/exclusão e focalizadores, de dicto (denegação, afirmação e focalização) e os circunstanciais (de lugar e de tempo).

Já na segunda entrada, percebemos uma dimensão sintática que implica em distinguir os Advérbios de constituinte, que tomam por sujeito um constituinte sentencial e os Advérbios de sentença que tomam por sujeito toda uma proposição. Foram deixados de lado os advérbios de discurso, como já mencionamos acima.

Castilho (1993) explica:

Posteriormente a essa primeira investigação, sucederam-se estudos particularizados sobre os Circunstanciais de tempo e lugar (NEVES, 1990), os Focalizadores e os Aspectualizadores (ILARI, 1990), os Modalizadores (CASTILHO e MORAES CASTILHO, 1990), os Delimitadores (MORAES de CASTILHO, 1992), os Qualitativos (OLIVEIRA, 1990) e os de Inclusão e Exclusão (POSSENTI, 1990). Logo depois, MERCEDES S. RISSO e CLÉLIA JUBRAN descreveram os advérbios textuais. (p.74-75).

Faltava um estudo dos advérbios predicadores que Castilho propôs-se a fazer, fazendo dessa forma avançar as reflexões já desenvolvidas, apresentando dessa grande classe uma visão mais integrada.

Dos estudos apresentados, o que diz respeito diretamente a este trabalho é o de Neves (1992). Ela afirma que antes de se conceituar o que são advérbios ou de dizer em que classes de palavras eles devem ser incluídos é preciso descrever suas funções.

A autora propõe-se a estudar a classe dos advérbios de lugar e de tempo, pois estes, de acordo com as definições da Gramática Tradicional, modificam o verbo, o adjetivo, ou outro advérbio. No entanto, quando se olha com atenção, vê-se que esta definição não se aplica aos circunstanciais. Mas ao levar-se em consideração a outra definição, que confere aos advérbios a função de indicar circunstâncias, os advérbios de lugar e de tempo são os advérbios por excelência.

Ela afirma, logo de princípio, que são categorias dêiticas "isto é, como categorias que provêm orientação por referência ao falante-agora, que é o complexo modotemporal que constitui o ponto de referência do evento de fala." (p.265-264) Essas duas classes, lugar e tempo, estão tão unidas que a um dêitico de lugar pode se somar uma indicação de tempo. 
(34) Lourdinha tá dizendo aqui que esse negócio de cadeira na calçada (...).

(D2-RE-05:26.1130-1131)

Os advérbios circunstanciais podem se subdividir em fóricos (relação intraenunciado) como em (35) e não-fóricos (relação enunciado/enunciação) como em (37). Os elementos não-fóricos podem entrar na constituição de sintagmas adverbiais fóricos como em (36) ou não-fóricos como em (37).

(35) isso eu estou fazendo aqui hoje

(D2-RJ-355:6.5-6)

(36) são considerados elementos chaves...dentro da sua estrutura....

(DID-RE-131:4.126-127)

(37) moro dentro dum jardim

(D2-RE-05:25.1027)

A autora ainda explica que os advérbios fóricos têm natureza pronominal e por isso são proformas ou proadvérbios, o que lhes confere um comportamento particular.

Quanto às funções sintático-semânticas, os advérbios de lugar e tempo podem ser Nucleares e, portanto, exercer função argumental, pois preencherão a casa de valência de um verbo (Ex 38), ou podem ser periféricos exercendo função adverbial ou adnominal. (ex 39)

(38) .. i meus irmão nu morava aqui meus irmão morava lá nu novu osasco...

(FIL. Inq. I: 696)

(39) ... ai trazia nessa rua aqui eu truxe muito trouxe muita broa de queijo...

(FIL. Inq. VIII: 21)

Vale ressaltar que os advérbios de lugar que desempenham função argumental, atuam como participantes, preenchendo uma casa de terceira pessoa. Têm essa função os advérbios fóricos que têm natureza pronominal, o que lhes permite funcionar como argumentos. Neves (2000) afirma que tais advérbios são muitas vezes chamados de advérbios pronominais, ou pronomes adverbiais. Também aqueles que indicam uma 
circunstância relativa a participantes localizáveis no espaço/no tempo, ou a estados de coisas, são considerados argumentos. Podem ser tanto fóricos como não-fóricos.

Já o advérbio é satélite quando exerce função adjuntiva adverbial. "Ele efetua circunstanciação, sendo locativo (no espaço ou no tempo) dos estados de coisas." (NEVES, 2000: 260).

A autora ainda descreve mais dois contextos em que os advérbios de lugar são periféricos. Quando exercem função adjuntiva adnominal, efetuam circunstanciação de nome de algo que seja localizável. São tanto os fóricos como os não-fóricos. E quando exercem função juntiva, efetuam junção temporal de enunciados, orações ou de sintagmas.

Quanto ao esquema sintático dos locativos adverbiais, a autora os divide em intransitivos, não-completáveis ou avalentes e completáveis transitivos. Os primeiros são os advérbios pronominais (ex 40) e os advérbios nao-fóricos, que não se constroem com um antecedente e um subsequente entre os quais exista uma relação espacial ou temporal (ex 41).

(40) Chegô um:....um:.... negrão muito entusiasmado aqui em São Tiago...

(FIL.Inq. VIII: 13)

(41) Bentinho viu logo que o ataque a Jatobá nao podia ser mais naquele tempo.

$(\mathrm{CA})^{12}$

Os completáveis ou transitivos são representados pelos não-fóricos relacionais: o advérbio vem completado por um sintagma iniciado por preposição (ex 42)

(42) Corria lá de dentro de sua alma um sangue que ninguém via.

Por fim, explica a autora que a característica semântica geral dos advérbios de lugar é a indicação de circunstância de lugar. Há três circunstâncias deste tipo: Situação, Percurso e Origem/ Direção. Neves (1992) faz uma classificação resumida das diferentes circunstâncias de lugar e afirma que só os advérbios de lugar situativos respondem à pergunta onde? diferente do que propuseram diferentes Gramáticas Tradicionais já consideradas. 
Blanche-Benveniste et al. (1984:26) afirmam

que o elemento pronominal seria o resultado, explícito ou implícito, de um processo de pronominalização, [o que é ]fundado frequentemente numa argumentação pragmática. Apenas recentemente os inconvenientes dessa abordagem foram denunciados por diversos autores. (...) Nós deduzimos uma teoria inversa da teoria herdada: é o pronome - ou a unidade subjacente induzida a partir do pronome - que constitui a base lingüística do enunciado. Os outros elementos podem ser apresentados como sendo do processo de lexicalização.

Este raciocínio nos faz entender que um termo pronominal e um termo nominal possuem uma relação de proporcionalidade e não de substituição. Devido a isso, Castilho (2001) investiga a estrutura argumental do verbo de uma outra maneira, que se parece em muito com a classificação proposta por Mira Mateus (1984).

Para ele, se o termo adjacente subcategorizado pelo verbo é proporcional a um pronome e se esse pronome for ele, e o verbo com ele concordar, identificamos o sujeito. No entanto, se este pronome for do caso oblíquo, ou se for preposicionado, identificamos um argumento interno que será objeto direto se o termo for proporcional aos pronomes me/te/o.Por outro lado, se o termo for proporcional ao clítico dativo lhe o argumento será um objeto indireto. Finalmente, se o termo é proporcional a uma preposição + ele, a um Advérbio de lugar, ou a um Demonstrativo neutro, esse argumento será um Oblíquo.

Por esta abordagem, vemos que o autor entende os advérbios de lugar como pronomes, uma vez que podem estar na função de argumento do verbo. Castilho (2001: 106) explica que "adjuntos são termos sentenciais ligados fracamente ao verbo e, por isso, mesmo, não pronominalizáveis". Mais tarde o autor explica que os advérbios de lugar e tempo indicam a circunstância em que se deu o estado de coisas descrito pelo verbo e por isso eles são decididamente dêiticos, e como podem funcionar como argumentos melhor se disporiam entre os pronomes.

\subsection{ABORDAGEM FUNCIONAL DE DIK}

Interessada por privilegiar uma perspectiva funcional para a nossa análise, buscamos apoio na Gramática Funcional (GF) de Dik (1989). Sabemos, no entanto, que não é uma tarefa fácil estudar uma classe tão heterogênea como a classe dos advérbios.

Isso é confirmado nor Awera (1998. 3 anud NOBREGA 2000) 
(...) the category [of adverbs] itself is elusive: it is not clear what the defining or prototypical features of adverbs and adverbials are, and consequently the borders with neighboring categories, especially, particle, but also adjective, adposition, and conjunction, are unclear too.(...) There seem to be many different subtypes of adverbs and adverbials.

Hengeveld (1997) afirma que devido ao grande número de funções que os advérbios desempenham e preenchem, eles têm prendido a atenção de alguns estudiosos. Em seu estudo ele pretende mostrar as posições de cada um dos tipos de advérbios e as funções que eles desempenham na oração de acordo com a Gramática Funcional proposta por Dik (1989).

A definição sintática de advérbio para Hengeveld (1997) é: “an adverb is a lexical modifier of a non-nominal head". Esta definição sugere algumas restrições: (i)Um advérbio não pode ocupar uma posição obrigatória pedida pelo verbo, ou seja, ele não pode ser um argumento, tem de haver na oração um outro termo que ocupe tal posição; (ii) apenas um item lexical pode ser considerado um advérbio. O autor exclui de sua definição, pelo menos do ponto de vista sintático, construções modificadoras. Assim:

a) Ela dança belamente.

b) Ela dança de um belo modo.

Em a) vemos um advérbio, um único item que por meio de regras derivacionais torna-se um modificador e em b) notamos a presença de um non-lexical adverbial construction, ou seja, é um adjunto adverbial que assume a função de modificador.

A ultima restrição (iii) afirma que os advérbios são distintos dos adjetivos, pois estes modificam nomes enquanto os advérbios modificam verbos, adjetivos ou até sentenças inteiras.

Dik (1989) mostra que em cada camada do modelo hierárquico da oração, observam-se operadores e satélites. Operadores são elementos gramaticais que expressam diferenças semânticas, enquanto os satélites são itens lexicais que veiculam informação adicional a uma das camadas da oração. Os satélites são caracterizados em termos gerais como modificadores de verbo. Os advérbios também receberam tal definição, assim na GF os advérbios ocupam o espaço na oração destinado aos satélites. 
A GF de DiK vale-se de critérios sintáticos e semânticos e propõe quatro tipos de satélites arrolados a seguir:

SATÉLITES $\sigma_{1}$ : representam os meios lexicais que especificam propriedades adicionais do conjunto do EsCo designado por uma predicação nuclear.

(44) Maria dançou lindamente.

SATÉLITES $\sigma_{2}$ : representam os meios lexicais que localizam (grifo nosso) o EsCo designado por uma predicação em um mundo real ou imaginário e assim restringe o conjunto de referentes potenciais da predicação à(s) situação(ões) que o falante tem em mente.

(45) Maria dançou lindamente aqui.

SATÉLITES $\sigma_{3}$ : incluem os meios lexicais pelos quais o falante especifica sua atitude para com a proposição.

(46) Maria provavelmente dançou lindamente aqui.

SATÉLITES $\sigma_{4}$ : representam os meios lexicais pelos quais o valor ilocucionário da oração pode ser especificado ou modificado, modificam, portanto o Ato de Fala e não o EsCo referido no ato de fala.

(47) Francamente, Maria provavelmente dançou lindamente aqui.

Hengeveld (1997) acrescenta a esta lista os satélites $\sigma_{5}$, satélites de enunciado. Esses satélites compreendem os meios lexicais por meio dos quais o falante aloca o ato de fala designado por uma frase dentro do contexto discursivo. Essa categoria de satélite não possui um operador correspondente.

Por fim, Hengeveld (1997) ensina que os advérbios organizam-se em uma sentença de acordo com a localização do predicado central desta sentença. Estabelece-se uma relação de escopo entre eles, assim:

(48)Primeiramente $\left(\sigma_{5}\right)$ francamente $\left(\sigma_{4}\right)$ Maria provavelmente $\left(\sigma_{3}\right)$ dançou lindamente $\left(\sigma_{1}\right)$ aqui $\left(\sigma_{2}\right)$

A ordem dos três advérbios que precedem o predicado reflete a relação de escopo entre eles. Nessa mesma direção estão os outros dois advérbios de $\sigma_{1}$ e $\sigma_{2}$. No entanto, Hengeveld (1997) ressalta que os advérbios com componentes dêiticos como os de $\sigma_{2}$ possuem um comportamento muito mais livre na oração do que os $\sigma_{1}$, por exemplo. Os de nível 1 estão muito mais ligados ao predicado do que os de nível 2. (Cf. em 4.2.3, 
Dik (1989:72) traça uma diferença entre argumentos e satélites. O autor explica que os argumentos são os termos exigidos por um predicado para que a predicação nuclear seja completa. "They are essential to the integrity of a SoA designated by the predicate frame. If we leave them out, the property/relation designated by the predicate is not fulfilled or satisfied.”. Por outro lado, os satélites são os termos opcionais, ou seja, aqueles que não são exigidos pelo predicado, "they give optional further information pertaining to additional features of the SoA (Level 1), the location of the SoA (Level 2), the speaker's attidute towards or evaluation of the propositional content (Level 3), or the character of the speech act (Level 4).”.

Outras diferenças podem ser traçadas como, por exemplo, as camadas a que estes dois termos se referem. Os argumentos necessariamente estão ao lado do predicado, enquanto que os satélites $\sigma_{1}$ estão relacionados à predicação central, os satélites $\sigma_{2}$ à predicação estendida, os de $\sigma_{3}$ à proposição e por fim os de $\sigma_{4}$ à cláusula. Ainda é válido mencionar que os argumentos ocupam na oração uma posição mais central, enquanto os satélites estão mais na periferia. Porém esta diferença entre estes dois termos, já que ambos são expressões que podem ser usadas para referir entidades, em alguns casos não é muito clara, principalmente quando se trata de satélites de nível 1.

The distinction between arguments and satellites would be an easy matter if we could simply say: arguments are obligatory, satellites are optional constituents of the clause, and: arguments are characterized by one set of semantic functions, satellites by another set, and these two sets do not overlap. In fact, however, matters are less straightforward than this, so that in certain cases it may be difficult to decide wheter a given term has the status of an argument or a satellite.

Esta dificuldade reside principalmente nos satélites de nível 1, já que a fronteira entre um argumento e este tipo de satélite é muito pequena, uma vez que ambos expressam propriedades internas do EsCo designadas pela predicação central.

$\mathrm{O}$ autor ainda afirma que certas funções semânticas podem marcar tanto argumentos como satélites. Veja o exemplo:

(49)a. Maria comprou um vestido aqui.

b. Maria mora aqui. 
Nos dois exemplos aqui possui a mesma função semântica de Locação, mas se deve observar os predicados de cada oração. Em a. aqui localiza o EsCo, dá a dimensão espacial de onde o vestido foi comprado por Maria. Já em b. aqui é um argumento do predicado morar. De fato, morar nesse sentido designa a relação entre um ser + animado e um locativo, logo o EsCo não seria completo se o termo locativo fosse retirado. $\mathrm{O}$ autor ensina que "a general test, then, for distinguishing arguments from satellites is the following: a satellite can be left out without affecting the grammaticality or the meaning of the remaining construction, whereas leaving out an argument will either render the remainder ungrammatical or changes its semantics." (p.74).

No entanto, tal critério não pode ser aplicado mecanicamente sem antes se levar em consideração o contexto em que o termo está inserido, assim como alguns uso de predicados chamados de absolutos.

(50) a. Maria está bebendo um copo de suco.

\section{b. Maria está bebendo.}

c. Maria bebe.

Em a) beber é um predicado de dois lugares, já em b) e c) o segundo argumento não é especificado, mas em c) pode ser entendido como hábito de se consumir bebida alcoólica todos os dias, logo o argumento um copo de suco não fará falta, e mesmo assim o termo antes referido não pode ser considerado um satélite.

Dik et al. (1990) traçam uma diferença entre os chamados satélites de nível representacional e os satélites de nível interpessoal. Antes de explicitarmos tal diferenciação valem algumas considerações sobre estes dois níveis. Hengeveld (1989 apud NEVES, 1997) afirma que o modelo de uma análise da "cláusula" em dois níveis pode ser considerado como uma certa integração do funcionalismo da escola da Holanda com o de Halliday. Assim, o nível representacional está relacionado com o evento narrado, o enunciatário compreende a que situação se faz referência. Já o nível interpessoal está relacionado com o evento de fala, o enunciatário reconhece a intenção comunicativa do enunciador. (Cf. em 4.24, p.64)

No nível representacional "estão os estado-de-coisas, entidades às quais as sentenças (como 'expressões referenciais', que ocorrem em algum tempo e lugar) se referem. No nível interpessoal há uma estrutura ilocucionária abstrata, que expressa a 
relação entre o falante, o destinatário e a mensagem, ou conteúdo transmitido." (NEVES, $1997: 93$ )

Dik et al. (1990) demonstram de quatro formas as diferenças entre estes dois tipos de satélites: (i) somente os satélites de nível representacional podem ser foco de uma sentença; (ii) os satélites de nível representacional constituem um único "bloco" de informação juntamente com a predicação central; (iii) somente os satélites representacionais $\left(\begin{array}{lll}\sigma_{1} \text { e } & \sigma_{2}\end{array}\right)$ podem estar sob o escopo do operadores ${ }^{13}$ de $\pi_{1}$ e $\pi_{2}$ e, finalmente, (iv) os satélites de nível representacional são tipicamente condicionados por outras propriedades pertencentes ao nível representacional, assim como os satélites de nível interpessoal possuem algumas restrições que são características do nível interpessoal.

O autor ainda faz distinções com relação aos satélites de predicado $\left(\sigma_{1}\right)$ e os satélites de predicação $\left(\sigma_{2}\right)$. Ele pretende mostrar que há várias diferenças entre os satélites do nível representacional, tais como: (i) comportamento argumentativo dos satélites de predicado; (ii) diferenças de ordem e posição; (iii) possibilidade de paráfrase; (iv) comportamento sob negação.

Dik et al. (1990) afirmam que dada a íntima relação dos satélites de $\sigma_{1}$ com o predicado, podemos esperar que os satélites de predicados se comportem de maneira similar como argumentos em alguns aspectos. Evidências para esse comportamento argumentativo podem ser encontradas em: i) possíveis funções do sujeito e do objeto; ii) o papel dos satélites na formação do predicado, e iii) limitação semântica na ocorrência de satélites.

A Hierarquia das Funções Semânticas (HFS) proposta por Dik (1989) representa uma tendência universal na atribuição das funções sintáticas. No continuum apresentado abaixo pode haver um ponto de corte que representa as possibilidades de cada língua.

${ }^{13}$ Os operadores, que podem ser de quatro tipos $\left(\pi_{1}, \pi_{2}, \pi_{3}\right.$ e $\left.\pi_{4}\right)$, compreendem os meios gramaticais responsáveis pela modificação de um EsCo. Os $\pi_{1}$ apreendem os meios gramaticais dos quais se especificam características adicionais sobre a natureza ou a qualidade do EsCo. Os $\pi_{2}$ representam os meios gramaticais por meio dos quais o EsCo designado pela predicação central pode ser quantificado e 


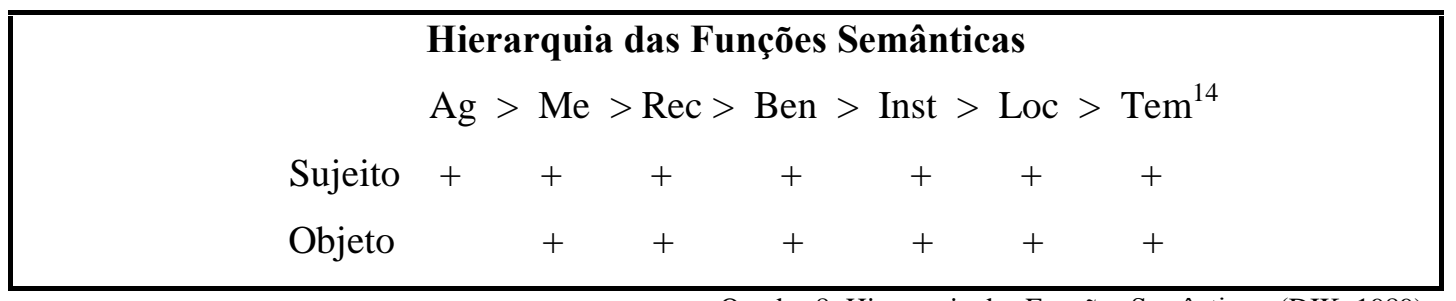

Quadro 8: Hierarquia das Funções Semânticas. (DIK, 1989)

Quanto mais à direita a função estiver, a atribuição das funções de Sujeito e Objeto se torna cada vez menos freqüente. Assim, um termo que desempenhe o papel semântico de Agente tem maiores chances de ser Sujeito que um termo que tenha o papel semântico de Beneficiário, por exemplo.

As funções semânticas de beneficiário e instrumento são claros exemplos de satélites de nível 1, pois eles contribuem para uma definição do EsCo. As funções semânticas de Locativo e Tempo representam um problema para esta teoria, pois pelo menos a princípio, são considerados satélites de nível 2, que não entram na definição do EsCo, mas somente servem para localizar este EsCo. Como eles poderiam então servir de ponto de partida para uma perspectivização do EsCo?

$\mathrm{O}$ autor explica mais a frente

that Loc does not necessarily have the status of a $\sigma_{2}$ satellite, which simply locates the whole SoA in some spacial domain. Locative terms can also have argument status and, depending on the way the notion 'locative' is used, they might also cover one or more of the 'inner' local or directional satellites which were assigned $\sigma_{1}$ status above. (DIK, 1990:44)

Dik (1989:2301 apud CAMACHO, 1999:148) "ressalta, todavia, que, na realidade, dependentemente da língua envolvida, Locativos podem manifestar-se como argumento, como satélite de nível 1, ou como satélites de nível 2".

Os satélites de nível 1 são também mais facilmente incorporados à predicação nuclear devido à sua relação mais "fechada" com o predicado. As regras de formação de um predicado não afetam somente os argumentos, mas também os satélites de nível 1.

Por exemplo:

(51) João sentou-se na cadeira no jardim.

${ }^{14}$ Leia-se as siglas como: Ag - Agente; Me - Meta; Rec - Recebedor; Ben - Beneficiário; Inst pdfMachine A pdf writer that produces quality PDF files with ease!

Produce quality PDF files in seconds and preserve the integrity of your original documents. Compatible across nearly all Windows platforms, simply open the document you want to convert, click "print", select the "Broadgun pdfMachine printer" and that's it! Get yours now! 
O locativo "inner" 15 representado por na cadeira pode ser incorporado pelo predicado, ao contrário do locativo "outer" no jardim, que claramente representa um satélite de nível 2. Por outro lado pelas "regras de absorção" de um predicado, um satélite pode fazer as vezes de um argumento. Na falta de um argumento que complete a predicação, o que era satélite pode assumir funções parecidas com as de um argumento.

\section{(52) a. Maria lava essa roupa. \\ b.*Essas roupas lava. \\ c. Essa roupa se lava facilmente.}

Em c. quando se retirou o agente Maria o predicado pediu algum outro termo para completar a predicação, assim o satélite facilmente assumiu um comportamento parecido com o de um argumento. "We assume that satellites will be more easily absorbed in this way when they are more closely associated with the nuclear predicated." (DIK 1990:50)

Já quanto às restrições semânticas para ocorrência dos satélites, percebemos que eles sofrem mais restrições quanto mais ligados ao núcleo da oração eles são. Os $\sigma_{1}$ estão mais intimamente relacionados ao predicado do que os $\sigma_{2}$, que assumem um comportamento mais livre. Assim como eles são também muito mais livres para ocorrer tanto no início como no final da oração.

(53) a. Ela beijou sua mãe na bochecha.

b. ?Na bochecha, ela beijou sua mãe.

(54)a. Ela beijou sua mãe na plataforma.

b. Na plataforma, ela beijou sua mãe.

"These ordering differences can be interpreted as 'iconically'refleting the relative scope differences between the satellites, in the sense that 'outer' or 'higher' satellites take 'inner'or 'lower'satellites in their scopes." (DIK, 1990:53) Mais evidências para as

${ }^{15}$ A expressão inner mostra que o termo e o predicado a que ele se refere possuem uma relação muito estreita, diferentemente do que representa a expressão outer, que mostra que o termo pode ser retirado da 
diferenças de escopos podem ser encontradas na ordem dos satélites de predicado e dos satélites de predicação relativos ao predicado:

(55)a. Ela beijou sua mãe na bochecha na plataforma.

b. Na plataforma, ela beijou sua mãe na bochecha.

c. ? *Ela beijou sua mãe na plataforma na bochecha.

d. ? *Na bochecha, ela beijou sua mãe na plataforma.

Desse modo, podemos perceber as diferenças entre os dois tipos de satélites do nível representacional. Os satélites $\sigma_{1}$ possuem um comportamento bastante parecido com o dos argumentos, além de serem mais presos ao predicado, diferentemente dos satélites $\sigma_{2}$, que possuem grande mobilidade na oração e são passíveis de paráfrases. Porém, como foi visto, as funções semânticas de Locativo e Tempo representam um problema para a teoria já que em algumas línguas elas podem estar na posição de Sujeito. Os autores deixam claro, no entanto, que quanto mais parecido os satélites de $\sigma_{2}$ forem com os $\sigma_{1}$ mais chances eles têm de exercer a função de Suj/Obj. Vimos ainda que quanto mais incorporados à predicação nuclear, mais um comportamento parecido com os de argumento os satélites terão.

Os satélites do nível representacional $\left(\sigma_{1}\right.$ e $\left.\sigma_{2}\right)$ têm comportamento diferente dos satélites do nível interpessoal $\left(\sigma_{3}\right.$ e $\left.\sigma_{4}\right)$ quanto à negação. Os satélites $\sigma_{1}$ e $\sigma_{2}$ entram no escopo da oração, no entanto, pelo fato de os satélites $\sigma_{2}$ possuírem um comportamento mais livre, em algumas orações, eles não entram no escopo da oração deixando, dessa forma, as sentenças ambíguas.

Uma ultima distinção é feita sobre os satélites restritivos e os não-restritivos. Quirk et al.(1985 apud DIK et al., 1990) usam esta distinção apenas para os satélites $\sigma_{1}$ e $\sigma_{2}$, pois segundo ele, os satélites $\sigma_{3}$ e $\sigma_{4}$ são necessariamente não-restritivos. Os satélites de $\sigma_{1}$ contribuem para a especificação do EsCo, por isso são não-restritivos. Já os satélites de $\sigma_{2}$ ora podem ser restritivos, ora podem ser não-restritivos, assim como eles aparecem em relação ao escopo da negação. Os satélites de predicado estão necessariamente sob o escopo da negação, os de predicação podem estar dentro ou fora do escopo da negação e os satélites de proposição e ilocucionários têm a negação em seu escopo.

Com todas estas distinções pode-se notar a grande diferença que existe entre os quatro tipos de satélites, principalmente os do nível representacional. Vê-se que os 
satélites de nível 2 apresentam uma posição mais livre na oração, podendo estar tanto no início quanto no seu final.

Apresentou-se ainda um problema quanto à diferenciação entre satélites de um mesmo nível. Os satélites de Tempo e os de Lugar que estão no $\sigma_{2}$, e que pertencem ao nível representacional, podem aparecer em um possível ponto de partida para uma perspectivização de um EsCo, ou seja, podem assumir posições de Sujeito.

Devido a este comportamento, observa-se que os termos ou advérbios que carregam estas funções semânticas também apresentam um problema para a classificação da Gramática Funcional. Não se sabe ainda ao certo onde alocá-los e qual a função que exercem. São questões ainda em aberto e que merecem maior atenção.

Todos os estudos arrolados neste capítulo foram de suma importância para mostrar aspectos relevantes do objeto de estudo deste trabalho, seja do ponto vista sintático, seja de um ponto de vista semântico. Notou-se que os termos locativos aqui, aí, lá e ali ora foram classificados como adjuntos ou satélites ora como complementos ou argumentos de predicado. Por isso, optou-se, com base na teoria funcionalista de Simon Dik, por estabelecer contextos que especifiquem quando tais locativos serão adjuntos ou satélites e quando desempenharão a função de argumento ou complemento, podendo também assumir, no interior do texto, outros valores como de operadores textuais. 


\section{CAPÍTULO 3 \\ O CORPUS SOB ANÁLISE}

\subsection{O PROJETO FILOLOGIA BANDEIRANTE}

Para estudar os advérbios locativos aqui, aí, lá e ali, utilizamos parte do corpus de língua falada do Projeto Filologia Bandeirante. Iniciado em 1998, sob a coordenação do Prof. Dr. Heitor Megale, tal Projeto realizou uma incursão em núcleos rurais de quatro estados brasileiros, localizado na rota dos bandeirantes ${ }^{16}$ (os caminhos percorridos à exaustão em busca do ouro das minas, nos séculos XVII e XVIII), com o objetivo de pesquisar dados lingüísticos que possam favorecer "a busca da ancianidade do português do Brasil” (MEGALE, 1998, In: OLIVEIRA, 2000:223). Pesquisadores das Universidades Federais de Minas Gerais, de Goiás, do Mato Grosso e da Universidade de São Paulo trabalharam a fim de constituir um corpus de língua falada - a partir da gravação de inquéritos junto a falantes idosos radicados em localidades fundadas por bandeirantes, ou que surgiram em conseqüência de sua passagem - e da língua escrita através da busca de documentos produzidos no período das bandeiras, ou que tenham algum vínculo com os bandeirantes.

Tal corpus é extremamente significativo para a história sociolingüística do português do Brasil. Na região do ciclo do ouro, o movimento das bandeiras adquiriu um caráter colonizador. Segundo Megale (In COHEN, 2000:212), "não há rota de colonização mais importante (do que as bandeiras) dentro do país, que tenha tido uma movimentação demográfica de maior repercussão". Alguns autores acreditam que as bandeiras tiveram um papel decisivo na penetração e posterior fixação da língua portuguesa nos sertões brasileiros ${ }^{17}$. Abreu (1883, 1930, In: MENDES, 2000:66), por exemplo, afirma que "foi no lombo de burro e pata do boi (...) que os sertões foram progressivamente conquistados e integrados na nova cultura que os descobridores trouxeram ao Brasil. E dessa cultura, que partia do litoral, fazia parte integrante a língua portuguesa".

${ }^{16} \mathrm{O}$ termo bandeirante se refere a um conjunto heterogêneo de pessoas que participavam de expedições ao sertão: portugueses, mamelucos, índios, negros e estrangeiros. O movimento das bandeiras é eminentemente paulista, com maior atuação dos moradores da Vila de São Paulo.

${ }^{17}$ MATTOS E SILVA (2001:286) observa que historiadores acreditavam que a língua geral (de base tupi) seria, até o século XVIII, a língua familiar da área cultural que mais tarde seria denominada "Brasil 
Documentando a realização oral das pessoas da zona rural que adquiriram a língua há 60 anos ou mais, o Projeto Filologia Bandeirante buscou colher traços da língua portuguesa antiga que tenham permanecido ao longo dos três séculos que nos separam do início do processo de colonização e povoamento dessas áreas. (COHEN et al., 1997:79). Teve, portanto, “o audacioso objetivo de buscar as raízes do português do Brasil falado nas trilhas das bandeiras, interpretando-o como uma modalidade conservadora, que reflete o falar seiscentista-setecentista trazido pelos colonizadores e implantado no Brasil pelos sertanistas (CASTILHO, 1997)" (OLIVEIRA, 2000:223).

\subsection{BANCO DE DADOS DO PORTUGUÊS POPULAR FALADO NA CIDADE DE SÃO PAULO}

A metade do material correspondente ao corpus que será objeto de análise neste trabalho foi extraída de 10 inquéritos, com duração de aproximadamente 30 minutos cada, gravados em favelas da periferia paulistana. Estes inquéritos pertencem ao Banco de Dados do Português Popular Falado na Cidade de São Paulo (doravante BD), cuja descrição pormenorizada está em Rodrigues (1987). A autora deu início à formação do BD a partir do ano de 1986, quando gravou e transcreveu 20 horas de entrevistas informais com quarenta informantes, selecionados a partir dos critérios de faixa etária (3 grupos: 20 a 35 anos; 35 a 50 anos; acima de 50 anos), grau de escolarização (grupos: analfabetos e semi-alfabetizados, que tenham cursado no máximo até a 4 árie primária), sexo e procedência. Foram entrevistadas apenas pessoas que não estavam freqüentando a escola. Uma amostra de seis inquéritos foi publicada junto com a tese de doutoramento acima citada.

Os demais inquéritos foram resultado dos trabalhos acadêmicos realizados no decorrer dos anos pelos alunos durante o curso de Sociolingüística do Português do Brasil II, da FFLCH-USP, ministrado pela Professora Dra. Angela Rodrigues.

\subsection{PERFIL SOCIAL DOS INFORMANTES}

Trabalhou-se com 20 inquéritos neste estudo. 10 inquéritos constituem parte integrante do Projeto Filologia Bandeirante. São informantes idosos (em média 78 anos) de ambos os sexos, analfabetos ou semi-escolarizados, nascidos e criados na zona rural dos estados de São Paulo e de Minas Gerais, na área correspondente às trilhas das 
bandeiras paulistas. Em sua grande maioria, são pessoas já aposentadas que trabalharam somente em atividades típicas do campo, ligadas à lavoura e à criação de gado.

Os outros 10 inquéritos fazem parte do material do Banco de Dados do Português Popular Falado na Cidade de São Paulo. Nesse conjunto há falantes de três faixas etárias - (i) 20 a 35 anos, (ii) 36 a 50 anos, (iii) mais de 50 anos - e de ambos os sexos, residentes na periferia da cidade de São Paulo. São adultos de baixa ou nula escolaridade, em sua maior parte, provenientes da zona rural, não só do estado de São Paulo, como de outras regiões do Brasil.

\subsection{O PORTUGUÊS POPULAR}

Os informantes cujas características são descritas no item anterior são autênticos falantes do português popular. Esta noção de variedade lingüística popular é construída com base em parâmetros sócio-culturais. Conforme a definição de Rodrigues \& Campos (2002:1), “português popular brasileiro, ou não-padrão, ou vernáculo brasileiro é aquela variedade de Português do Brasil utilizada por brasileiros do mundo rural ou do mundo urbano, analfabetos ou de baixo nível de letramento, que não têm na língua escrita possível modelo de realização oral”.

O grau de escolaridade constitui, portanto um parâmetro decisivo para a caracterização do estrato sociolingüístico popular:

por não terem acesso à escola, que, em tese, constitui instrumento de divulgação de um padrão culto de realização lingüística, tendem a manter os hábitos adquiridos na fase de aquisição e definição de seu vernáculo. Se já nos primeiros anos de vida aprenderam a dominar os mecanismos básicos do português oral, a sociedade não lhes permite, ou deles não exige, no decorrer da vida, alcançar outros estágios no processo de aquisição ou aprendizagem da língua materna, ou certas habilidades de expressão que instituições sociais típicas, como a escola, se encarregam de difundir.(RODRIGUES \& FERREIRA NETTO, 2000:172).

Segundo Rodrigues (1987), o português popular constitui uma variedade lingüística eminentemente de cunho oral, não-codificada e não-normalizada, que tende a modificar-se com maior vitalidade, posto que abrange variação em todos os níveis. Embora seja uma variedade de menor prestígio, que pode servir de índice de classificação social, ela cumpre perfeitamente as necessidades comunicativas de seus 


\section{CAPÍTULO 4}

\section{ANÁLISE DOS DADOS}

\subsection{LOCATIVOS E FUNÇÃO DE ARGUMENTO E SATÉLITE}

Seguindo a metodologia da Sociolingüística Quantitativa, estabelecemos fatores de natureza lingüística que condicionariam o aparecimento de locativos exercendo ora a função de argumento ora a função de satélite. Os fatores foram formulados a partir da leitura de textos sobre a lingüística funcional (DIK, 1989; HENGEVELD, 1997; HENGEVELD 1989 apud NEVES, 1997; DIK et al. 1990). Foram estabelecidos os seguintes fatores: tipo de locativo, tipo de EsCo, posição dos advérbios, possibilidade de deslocamento do locativo na oração, planos narrativos.

Após a codificação de todas as ocorrências de acordo com os fatores lingüísticos estabelecidos, os dados foram submetidos a alguns programas do pacote Goldvarb, os quais nos forneceram:

(1) a freqüência geral de locativos como argumentos e como satélites, bem como a freqüência destes associada aos fatores estabelecidos;

(2) a seleção por ordem de importância dos fatores estatisticamente pertinentes (programa Step Up);

(3) os fatores descartados como numericamente irrelevantes (programa Step Down);

(4) os pesos relativos referentes às funções de argumento e satélite, conforme os fatores lingüísticos relevantes - cálculo que permite uma visão mais apurada dos dados, uma vez que leva em conta a relação entre o conjunto de fatores presentes em um determinado contexto. Os valores dos pesos relativos vão de 0.0 a 1.0. Um fator com peso relativo: (i) maior que 0.5 pode favorecer o surgimento do locativo como argumento ou satélite em um determinado contexto, assim como um fator com peso relativo inferior a 0.5 desfavorece a aparição do locativo como argumento ou satélite em outro contexto;

(5) o cruzamento dos fatores (programa Crosstab).

Feitos os cálculos estatísticos foram selecionados os fatores posição dos advérbios, tipo de EsCo, possibilidade de deslocamento do locativo na oração, planos narrativos. 
Apenas o fator tipo de locativo foi descartado pelo programa como não sendo relevante para a análise.

È necessário esclarecer que em virtude de trabalharmos com duas variáveis argumento e satélite - e sempre fazermos tabelas em que as duas aparecessem lado a lado, optamos por fazer duas rodadas dos programas Goldvarb. A primeira rodada com os locativos em função do argumento e a segunda, em função dos satélites.

\subsection{CONTEXTOS E FATORES ANALISADOS}

Já dissemos que o objetivo de nosso trabalho é discutir possíveis contextos em que os advérbios locativos aqui, aí, ali e lá poderiam aparecer exercendo a função de Argumentos ou Satélites de um EsCo.

Para estabelecermos se um locativo seria argumento ou satélite realizamos um teste proposto por Dik (1989.74). Ele ensina que "for distinguishing arguments from satellites is the following: a satellite can be left out without affecting the grammaticality or the meaning of the remaining construction, whereas leaving out an argument will either render the remainder ungrammatical or changes its semantics." (Cf. em 2.3, p.46)

No exemplo a seguir apresentamos como o teste foi feito.

(56) ...eles tava morando aqui...depois que foru embora...

(FIL. Inq. IV: 54)

(57)... eles tava morando...depois que foru embora...

Vemos que em (56) a predicação está completa. No entanto quando retiramos o locativo em (57) percebemos que o EsCo sofre uma perda semântica, uma vez que o predicado morar pede um complemento de lugar.

Já no exemplo abaixo o locativo pode ser retirado da oração sem prejuízo ao entendimento desta.

(58) e eles tinha muito escravo lá e eles conservam muita coisa lá ainda...

(FIL. Inq. X: 127)

Vemos que em (58) o locativo lá localiza o EsCo, dá apenas a dimensão espacial de onde havia muitos escravos, e, por isso, se retiramos o locativo, a predicação nuclear

\section{pdfMachine}

A pdf writer that produces quality PDF files with ease!

Produce quality PDF files in seconds and preserve the integrity of your original documents. Compatible across

nearly all Windows platforms, simply open the document you want to convert, click "print", select the

"Broadgun pdfMachine printer" and that's it! Get yours now! 
(59) e eles tinha muito escravo e eles conservam muita coisa ainda...

Realizados os testes que determinaram quais locativos eram argumentos e quais eram satélites, estabelecemos algumas variáveis que nos ajudaram a definir os contextos em que poderíamos assegurar com certeza quando o locativo assumiria alguma das funções já mostradas acima. São eles:

(i) tipos de EsCo - Ação, Estado, Posição e Processo;

(ii) posição dos advérbios - Posição inicial, Antes do verbo, Depois do verbo e Depois do objeto;

(iii) possibilidade de troca de lugar do advérbio na oração;

(iv) planos narrativos - Narrativo e Comentário.

A seguir, tecemos considerações sobre cada uma das variáveis utilizadas.

\subsubsection{TIPOS DE ESCOS}

Consideramos quatro tipos de EsCos em nossa análise: Ação, Posição, Estado e Processo. Partimos da hipótese de que os EsCos de Posição e de Estado abrigariam o maior número de ocorrências de locativos com a função de argumento de predicado, pois estes EsCo são constituídos por predicados [-din], em que não ocorre nenhum tipo de mudança. Pertencem a estes dois EsCos predicados que pedem algum tipo de complemento de lugar, como morar, ficar, estar, permanecer e ter, e que são bastante recorrentes em nossos dados.

A seguir apresentamos exemplos de cada um dos EsCos considerados para a análise.

Um EsCo mais dinâmico [+din] e mais controle [+con] caracteriza um tipo Ação. Trata-se daquele em que há uma mudança no EsCo e o primeiro argumento determina a realização do EsCo.

(60) “... eu tenho uma vizinha minha só que ela estuda na escola de baixo aí as vezes eu venho com ela até a escola aí depois eu subo aqui o asfalto... porque ela estuda naquela escola ali que tem perto dos prédio aí eu venho sozinha”

(PP. Inq. XI: 335)

(61) “... um rio que antes... quando eu cheguei aqui tomei muito banho porque ali era mato descia aquela água limpa eu lavava ropa... eu e os morador que não tinha 
água aqui... e a gente tomava banho naquela () a gente olhava via a areia... aquela coisa linda... e.: mais era uma coisa linda mesmo..."

(PP. Inq. XV: 627)

(62) “tudu mundo qui tava com dor di denti ia lá pa ele ven/ pa ela benzê viu? tudu mundo qui tava com dor di denti ia lá pa eli benzê..".

(FIL. Inq. I: 145)

(63) "qui aqui num tinha...é num muitu tinha carru aqui purque aqui num tinha esse asfalto...ah...agora feiz esse asfalto aqui cabô tudu”

(FIL. Inq. XVIII: 3)

Um EsCo Posição é aquele em que não ocorre nenhum tipo de mudança, ele é [din] e o primeiro argumento tem o poder de determinar a realização do EsCo.

(64) "Num vendí ...deixei lá, do jeito que ... eu tô aqui passando uns tempo, passando aqui...”

(PP. Inq. XIV: 71)

(65) “Doc.1 cê tem parentes lá na bahia marcia?

\section{Inf. minha mãe meu pai moram lá...meus tios tias tudu mora lá"}

(PP. Inq. XX: 73)

(66) “ói morava di agregadu purque aondi eu morava lá só era dus otru era du seu vergueru i dus otru tudu né? fiquei lá muitu tempu ... antigu us fazenderu tinha aqueles colônia na fazenda né?"

(FIL. Inq. V: 83)

No EsCo de Estado também não ocorre nenhum tipo de mudança, ou seja, ele também é [-din] assim como o EsCo Posição, mas o primeiro argumento não tem a propriedade de determinar a realização do EsCo, diferentemente do EsCo apresentado acima.

(67) "ah iscondi () até agora iscondi () a criançada aí ih agora tem criança aí qui nu acaba mais né?"

(FIL. Inq. VI: 1122)

\section{pdfMachine}

A pdf writer that produces quality PDF files with ease!

Produce quality PDF files in seconds and preserve the integrity of your original documents. Compatible across nearly all Windows platforms, simply open the document you want to convert, click "print", select the 
(68) “teve... é p’que... eu num sei ... ele é lá da USP... tá num poste o nome dele... esqueci o nome dele... não sei ele é lá da USP... parece que... é da USP...é que... é que deu... a mão né e graças a deus hoje temo o São Remo tudo asfaltado"

(PP. Inq. XV: 585)

(69) “... exatamente... incrusive um tempo desse aí teve um entupimento lá em cima nessa rua ai"

(PP. Inq.XIX:336)

Por fim, o EsCo de Processo é aquele em que ocorre uma mudança no EsCo, ou seja, é [+din] e o $1^{\circ}$ argumento não tem controle sobre tal mudança, logo é [-con].

(70) "Chegava a tremer esse boteco ai por exemplo...eles tinha que botá arame assim nas pratelera...pra segurá as garrafa pa não caí no chão...”

(FIL. Inq. X: 48)

(71) “Doc. e o senhor nasceu onde?

Inf. Eu nasci aqui”

(FIL. Inq. III: 2)

(72) “De veiz im quandu alaga aqui tudinhu ... aqui atrais... agora aqui num alaga mais não [ inint ] agora esse otro ladu aqui num alaga”

(PP. Inq. XIII: 308)

\subsubsection{POSIÇÃO DOS ADVÉRBIOS}

Dik (1989) ensina que os argumentos são termos exigidos por um predicado para formar uma predicação completa. São essenciais para a integridade dos EsCos designado pelo esquema de predicado. Já os satélites de nível 2 são meios lexicais opcionais que veiculam informações adicionais, que localizam o EsCo em um mundo real ou imaginário. (Cf. 1.1, p.17 e 18). Ainda DIK (1989) afirma que os argumentos estão ao lado do predicado, ocupando, assim, uma posição mais central, enquanto os satélites estão mais na periferia da oração. Complementando os ensinamentos de Dik (1989), Hengeveld (1997) explica que os advérbios organizam-se em uma sentença de acordo com a localização do predicado central dessa sentença e que os satélites de nível 2 possuem um comportamento muito mais livre na oração.

\section{pdfMachine}

A pdf writer that produces quality PDF files with ease!

Produce quality PDF files in seconds and preserve the integrity of your original documents. Compatible across nearly all Windows platforms, simply open the document you want to convert, click "print", select the "Broadgun pdfMachine printer" and that's it! Get yours now! 
Com base nisso, procuramos verificar se os locativos, quando argumentos de predicado, ocupam as posições imediatamente ao lado do predicado, mais precisamente a posição depois do verbo (3) e se quando satélites ficam, de fato, nas posições mais periféricas da oração, como a posição depois do objeto (4).

Para tanto consideramos quatro posições a serem observadas: Inicial (1), Antes do Verbo (2), Depois do Verbo (3) e Depois do Objeto (4).

A seguir exemplificamos cada uma das posições apresentadas.

\subsubsection{POSIÇÃO INICIAL}

Quando o advérbio locativo aparece logo no início de uma oração, ele pode aparecer exercendo a função de conector de texto ${ }^{18}$, como podemos notar em (73) ou com uma função dêitica, como em (74) e (75).

(73) “...aí eu falava e mãe eu num gosto desse negócio só por causa de trocá os cobre...ela falava não mais o povo depois paga o povo depois pagava né?...aí trazia nessa rua aqui...”

(FIL. Inq. IV:20)

(74) “...aqui u governu nem sabia quantus existia nu mundu...nu tinha registru ...”

(FIL. Inq. I: 259)

(75) “a gente tá chegando à época das águas...certo... e eu falo pro senhor... aqui dentro de casa aqui... quase entrô água... num entrô por causa de dois centímetro”

(PP. Inq. XVI:135)

\subsubsection{POSIÇÃO ANTES DO VERBO}

È a posição imediatamente anterior ao verbo. Tinhamos como pressuposto que os locativos permanecessem nessa posição quando são argumentos de predicado, no entanto nossos dados não confirmaram tal fato.

(76) “... você tem muita menIna e aqui tem uma horta muito boa....”

${ }^{18}$ A expressão aí chamou nossa atenção, pois aparece com grande freqüência nesta posição exercendo a função de conector de texto e, por isso, realizamos estudo em separado, em 4.8, sobre este 
(FIL. Inq. VIII:51)

(77) “até ai essi homi eu eu achei uma graça eli falá issu i é verdadi purque aqui conheço uma mulher coitadinha qui anda vendenu verdura pa rua ela casô no religiosu”

(FIL. Inq. IX:457)

\subsubsection{POSIÇÃO DEPOIS DO VERBO}

É a posição imediatamente após o predicado.

(78) “... dai eu falei eu fui lá i falei pra eli queu tinha: :. 'u casamentu é tar dia tar mei tar dia e como é o sinhor vai: :: mi dá u (murim)?'”

(FIL. Inq. IX: 431)

(79) “antes de clareá totalmente o dia porque assim que clareava os passarinho já tava lá pra arrancar o arroz quando plantava né ..."

(PP. Inq. XII:242)

(80) "e eu estudei lá ... mai bem poquinhu tamém"

(PP. Inq. XIII:343)

(81) “num podi ...é melhó dexá ondi tá... num podi é igual o rapaiz aí.. essa semana meтu... qui choveu ali imbaxu... choveu aqui tamém...ná mai só qui lá imbaxu é pior"

(PP. Inq. XIII:374)

\subsubsection{POSIÇÃO DEPOIS DO OBJETO}

É a posição logo após o argumento. Nossa hipótese é a de que os locativos adverbiais ocupem preferencialmente esta posição quando assumem a função de satélites de predicado. 
$(82)$

"Doc- Ela fica com as criança...mas aqui o senhor acha que tá dando mais pra juntar que lá?

Inf aqui uma parte pra mim tá muito mais melho... pra mim é sempre mais melhor...pra mim... tem cunvivência melhor... que eu tenho cunhecimento aqui ... bastante..."

(PP. Inq. XIV: 73)

(83)

"Doc. mais lá é mais friozinho nesses meis... então?

Inf. ...é... lá é mais chuvoso no meis de janero...de novembro pra frente são os meis são os meis mais... entendeu...que o pessoal se prepara...quando o pessoal vê um relampio lá no nordeste... todo mundo já pega sua enxadinha (risos) já vai pra roça...”

(PP. Inq. XV: 149)

(84) “no aniversáriu dos amigo...elas pede biCHIga levá guaraNÁ pa com/pa: :: comemorá com os amiguinho lá...é sempre assim a creche é ótima...não tem do que recramá"

\subsubsection{TROCA DE POSIÇÃO}

(PP. Inq. XVI: 65)

Hengeveld (1997) ressalta que os advérbios com componentes dêiticos como os satélites de nível 2 possuem um comportamento mais solto na oração do que os satélites de nível 1. (Cf. em 2.3, p.45). Os de nível 1, que se assemelham muito aos argumentos e que ocupam uma posição mais central na sentença, não possuem grande mobilidade na oração; já os satélites de nível 2 podem aparecer tanto no início quanto no final da oração.

Com base nesses argumentos, resolvemos analisar se de fato os locativos aqui, aí, ali e lá possuem mobilidade na oração até mesmo quando exercem a função de argumento, ou se este comportamento só é aceitável quando estes possuem a função de satélite. O teste de troca de posição, de deslocamento no eixo sintagmático, foi feito para observar esta propriedade dos satélites de nível 2.

Nos exemplos abaixo mostramos como procedemos em nossa análise. 
(85) “... conseguiu um serviço temporário no ano passado numa loja... aí... o cara falô que ia chamá ele de volta num chamô... e ele fez amizade lá... eles gosta muito dele sempre pergunta... mais num chamô... e até agora ele tá sem trabalho..."

(PP. Inq.XIX:276)

Neste exemplo,o locativo é um satélite e a troca de posição é possível, havendo somente uma pequena mudança na curva entonacioal, resultado da ênfase dada ao advérbio, o que lhe confere o estatuto de foco. Se colocarmos o locativo antes do verbo, o sentido da oração permance o mesmo:

(86) “...e ele $\mathbf{l} \grave{\boldsymbol{A}}$ fez amizade..."

Também é possível alocar o advérbio locativo lá na posição inicial. Nesse caso,ocorre o mesmo que na frase anterior, sem comprometimento de seu conteúdo informacional.

(87) “ e LÁ ele fez amizade...”

No exemplo a seguir, o locativo tem a função de argumento.

(88) “tempo... tempo num fais não... tá com uns treis... quatro meses que eu não vejo... inclusive meus irmãos tiveram perguntando dele pra mim... porque o último lugar que ele teve morando aqui em casa...né... mais eu não sei onde ele tá... falá a verdade... ninguém sabe"

(PP. Inq. XVI:667)

A troca, nesse caso, tembém pode ser realizada com uma pequena alteração da curva entonacional ou das pausas, na medida em que presume função discursiva diferente.

(89) “...Aqui em casa ele teve morando..."

Ou ainda

(90) "ele aqui em casa... teve morando"

Vemos assim que quando a troca foi permitida, os advérbios continuaram com a mesma função sintática e semântica de antes, só alterando a função discursiva.

No exemplo a seguir a troca não pode ser feita: 
(91) “a/ a/aqui nu tinha aqui nu tinha (quandu nóis chegô aqui) nu tinha índio... indio é só () cutia... () aqueli casarão... tá lá...só em cutia...só lá qui tinha u a casa dus dus iscravu... só lá...i tá lá... quem quisé i vê (qué vê) tá lá a casa lá...i é enorme du mundu a casa é casa di pião qui fala u nomi casa di pião... tá lá a casa...( )”

(FIL. Inq. I:492)

Esse é o único contexto que apareceu em nosso corpus em que a troca de posição apresenta um problema. Para se realizar a troca no exemplo acima é preciso fazer uma grande modificação na curva entonacional da oração. Outro fator que nos ajudou a concluir que a troca neste caso não é apropriada, foi o fato de não encontramos em nossos dados nenhuma ocorrência com o locativo a frente do predicado estar quando este se apresenta na forma tá.

Se a troca pudesse ser feita a oração ficaria da seguinte maneira:

(92) “aqueli casarão...LÁ tá....só em cutia...”

É válido lembrar que nesse exemplo lá não se refere ao termo casarão, mas à cidade de Cotia. Se o locativo fizesse referência a casarão a troca poderia ser efetuada, como podemos ver no exemplo (93).

(93) “aqueli casarão LÁ... tá em cutia...”

\subsubsection{PLANOS NARRATIVOS}

A última variável a ser considerada foi escolhida levando-se em consideração explicações de Hengeveld (1989 apud NEVES, 1997) sobre um modelo de análise da “cláusula" em dois níveis baseado em uma integração dos funcionalismos da escola da Holanda com a de Halliday. Dessa forma, o nível representacional, que abriga a predicação, está relacionado com o evento narrado, o enunciatário compreende a que situação se faz referência. Já o nível interpessoal está relacionado com o evento de fala, o enunciatário reconhece a intenção comunicativa do enunciador. (Cf. em 2.3, p.46)

Assim, compreendemos que os satélites de nível 2 e os argumentos estão relacionados aos eventos narrados, já que fazem parte da predicação, que constitui o nível representacional. 
O corpus analisado constitui-se basicamente de narrativas orais nas quais os informantes discorrem sobre assuntos que os levam, muitas vezes, a um alto grau de descontração, como foi visto no capítulo 3 desta dissertação.

Essas narrativas apresentam trechos em que os informantes relatam suas experiências e trechos em que os falantes tecem comentários acerca do que foi dito, como aparece no exemplo a seguir:

“Inf. mais acho que é da alemanha né?...é então dai é...o primeru dia queu vi ela eu falei comigu (otru dia) era uma uma muié arta bem arta né? o pé dela era bem grandão assim o pé dela ((risos)) os pé bem grandão del

Doc.2 ela era alta né?

Inf. ih a muiérona

Doc. 1 a caterina?

Doc. 2 é a

Inf. é muiérona...daí passemu a noite aí... a a sogra qui era sogra du calecu ficô sogra meтu (porque depoi calé casô) () )... a sogra do caletu (feiz piru) () história da () dai já foi embora... di madrugada foi imbora... ( ) lá da minha casa queu morava lá... di madrugada... foi imbora...daí prontu nunca mais veio pra cá...nunca mais veiu pra cá dai cabô nu veiu mais pra $c a ́$

Doc.2 o vô já já ta/ já/ a senhora nu viu o vô??

Inf. daí não que nem co/ nem vi seu avô nem nada nu vi nada i eli tava aí eu nu vi nada...depois passô u tempu passô u tempu passô u tempu tem/ um dia tinha uma muié qui morava na banca da ( )... i ela nu tinha filho... ai o nome dela é madalena i ela era casada com (matia) jeca...então pra fazê compra im itapecerica ela pediu eu pra i juntu fazê compra...fazê compra nu () aquel tempu aqueli... a muié não andava muito sozinha...aí eu vi seu vô lá na cidade...”

(FIL. Inq. I: 23)

Percebemos, no exemplo, que a informante relata a sua experiência quando recebera a visita de uma alemã, que lhe chamou a atenção por ser muito alta, e depois de quando encontrou seu marido em uma feira. Os fatos que constituem o núcleo de sua narrativa (vi, falei, passamos, ficou, casou, fez, foi, veio, passou, pediu) estão expressos 
pano de fundo para os acontecimentos passados ( era, morava, estava, andava) pelos de pretérito imperfeito.

Tal fato é confirmado pelo trabalho de Rodrigues et al. (1996).

Os eventos que constituem o núcleo da narrativa são representados por formas de pretérito perfeito, que sinalizam momentos passados com relação ao MF (momento de fala), tidos como efetivamente ocorridos, acabados, cronologicamente ordenados uns em relação aos outros; as formas de pretérito imperfeito compõem o pano de fundo para os acontecimentos relatados.

Pensando na inclusão dos argumentos e satélites de nível 2 no nível representacional, conforme sugerido por Hengeveld (1989 apud NEVES, 1997) e tendo observado as ocorrências em nosso corpus de locativos ora constituindo parte principal da narrativa e ora apenas fazendo parte das informações secundárias desta, separamos nossas ocorrências em dois tipos, de acordo com dois planos narrativos - o narrativo e o comentário.

Encontramos em Hopper (Cf. HOPPER, 1979, 1982; HOPPER e THOMPSON, 1980 apud RODRIGUES et al. 1996) a proposta que nos ajudou no entendimento e na classificação das ocorrências. O autor afirma que, em qualquer situação de fala, algumas partes do que é dito são mais relevantes do que outras. A parte do discurso que não contribui imediata e decisivamente para os objetivos do falante, mas que meramente os amplifica e os comenta corresponde ao fundo ou $2^{\circ}$ plano em contraposição, o material correspondente aos pontos principais do discurso é chamado de figura ou $1^{\circ}$ plano.

Assim, a maioria das ocorrências em que apareciam os locativos junto a verbos no pretérito perfeito foi classificada como pertencentes ao $1^{\circ}$ plano ou narrativo, já aquelas em que apareciam junto a verbos no pretérito imperfeito ou presente foram entendidas como pertencentes ao $2^{\circ}$ plano ou comentário.

Procurou-se, então, nessa análise, relacionar as propriedades sintáticas e semânticas às textuais. Partimos da hipótese de que os locativos quando junto de EsCos de Estado constituiriam um Comentário e quando junto de EsCos de Ação uma Narrativa, conforme visto em Nogueira (2003) ${ }^{19}$.

${ }^{19}$ Em nosso trabalho de Iniciação Científica, já havíamos atentado para o fato de que os verbos ditos de Estado entravam na constituição de um tipo de texto diferente daquele em que estavam os verbos de Ação, 


\subsection{CONTEXTOS DE USO DOS LOCATIVOS}

\subsubsection{OS LOCATIVOS E AS FUNÇÕES ARGUMENTO E SATÉLITE}

Foram analisadas 961 ocorrências de locativos. Abaixo está uma tabela que mostra quais foram os locativos que mais apareceram em nosso corpus e como eles estão distribuídos entre Argumentos e Satélites.

\begin{tabular}{c|c|c|c} 
& Argumentos & Satélites & total \\
\hline Aqui & $296 / 68 \%$ & $137 / 31 \%$ & $433 / 45 \%$ \\
\hline Aí & $47 / 55 \%$ & $37 / 44 \%$ & $84 / 8 \%$ \\
\hline Lá & $238 / 63 \%$ & $135 / 36 \%$ & $373 / 38 \%$ \\
\hline Ali & $45 / 63 \%$ & $26 / 36 \%$ & $71 / 7 \%$ \\
\hline total & $626 / 65 \%$ & $335 / 34 \%$ & 961 \\
& & \multicolumn{2}{|c}{ Tabela 1: Função que os locativos desempenham na oração. }
\end{tabular}

Nota-se que os advérbios locativos predominantes foram aqui e lá com respectivamente $45 \%$ e $38 \%$ do total das ocorrências. As formas aí e ali não foram muito representativas, apareceram em apenas $8 \%$ e $7 \%$, respectivamente, do total de ocorrências. É válido lembrar que não consideramos para a análise dos locativos, enquanto argumentos ou satélites, a forma aí exercendo sua função de conector de texto. No entanto, devido ao fato de esta forma aparecer em grande quantidade em nosso corpus com essa função, demos-lhes tratamento em separado em 4.8.

A língua portuguesa tem um sistema de locativos que corresponde aos demonstrativos este (próximo àquele que fala), esse (próximo àquele com quem se fala) e aquele (distante do falante e do ouvinte). Os respectivos locativos para esta tripartição são aqui, aí e ali. Em outra série dicotômica opõem-se cá próximo ao falante e lá distante do falante, com uma forma intermediária acolá, em oposição a lá para distinguir dois locais distantes do falante.

Mattoso Câmara (1975:121) ensina que os dois sistemas portugueses, tanto o tripartido (aqui, aí, ali) como o bipartido (cá, lá/ acolá) designam situação ou direção indiferentemente (fica aí, venha aqui, está lá, vai lá, vem cá). Diz ainda que

no uso, tanto de Portugal como do Brasil, há desbordamento de um sistema sobre o

outro. O português padrão de Lisboa, por exemplo substitui aqui por cá, enquanto 
no Brasil cá é de emprego esporádico. E de maneira geral, lá acrescenta-se freqüentemente à série aqui, aí, ali para indicar maior distância que ali ou uma situação mais vaga. Na linguagem coloquial do Brasil, acolá é quase tão esporádico como cá.

No sistema dicotômico cá, lá/acolá o uso de cá e acolá é bastante esporádico no PB do Brasil, sendo assim, optamos por juntar a forma lá ao sistema tripartido aqui, aí e ali, constituindo-se, assim, nosso material de estudo.

Talvez, pelo fato de a diferença entre as formas ali e lá não ser mais muito clara na língua falada, nota-se uma preferência pelo uso da forma lá em substituição à forma ali. Tal hipótese se confirma quando olhamos para as porcentagens na tabela acima: $38 \%$ de ocorrências de lá e apenas $7 \%$ de ali.

A forma aí apareceu em pequeno número, pois não foi considerada esta forma com o valor de conector textual.

Ainda de acordo com a tabela, conseguimos observar a quantidade de cada locativo na função de argumento ou de satélite. Podemos notar que os locativos apareceram com maior freqüência quando eram argumentos de predicado.

O locativo aqui apareceu em $68 \%$ das ocorrências como argumento e somente em $31 \%$ como satélites. Já para lá e ali a porcentagem é igual, em $63 \%$ das ocorrências estes locativos apareceram como argumentos e em $31 \%$ como satélites. Por último, ali apresenta $63 \%$ das ocorrências com a função de argumento e $36 \%$ delas como satélite.

Esta primeira tabela já nos responde à pergunta que fizemos no início de nosso trabalho. Os locativos adverbiais podem ser tanto argumentos como satélites, no entanto há no corpus analisado uma preferência pela função argumento.

\subsection{OS EsCos E A FUNÇÕES DE ARGUMENTO E SATÉLITE.}

Considerem-se os resultados abaixo

\begin{tabular}{c|c|c|c} 
Ação & Estado & Posição & Processo \\
\hline $475 / 961=49 \%$ & $297 / 961=30 \%$ & $161 / 961=16 \%$ & $28 / 961=2 \%$ \\
& & Tabela 2: EsCos analisados.
\end{tabular}

Dos quatro tipos de EsCo estudados pudemos perceber que os EsCos de Ação são os que mais apareceram com $49 \%$ do total das ocorrências, em seguida os EsCos de 
Estado com $30 \%$, Posição com $16 \%$ do total das ocorrências e, por fim, Processo com apenas $2 \%$, como observamos na tabela acima.

\begin{tabular}{|c|c|c|c|c|}
\hline \multirow[b]{2}{*}{ EsCo } & \multicolumn{2}{|c|}{ Argumento } & \multicolumn{2}{|c|}{ Satélite } \\
\hline & Freqüência & Peso relativo & Freqüência & Peso relativo \\
\hline Ação & $219 / 475=46 \%$ & 0.16 & $256 / 475=53 \%$ & 0.84 \\
\hline Estado & $235 / 297=79 \%$ & 0.80 & $65 / 297=20 \%$ & 0.19 \\
\hline Posição & $159 / 161=98 \%$ & 0.94 & $2 / 161=1 \%$ & 0.05 \\
\hline Processo & $13 / 28=46 \%$ & 0.05 & $15 / 28=53 \%$ & 0.94 \\
\hline Total & $626 / 961=65 \%$ & & $335 / 961=34 \%$ & \\
\hline
\end{tabular}

Os resultados dos cálculos de freqüência mostram que os locativos se distribuem de maneira equilibrada nos EsCos de Ação. De um total de 475 ocorrências que apareceram no corpus, em 219 ocorrências os locativos aparecem como Argumentos e em 256 ocorrências como satélites do predicado. Assim, vemos que os locativos adverbiais podem aparecer junto dos EsCos de Ação como argumentos e como satélites, o número é bastante equilibrado. Por outro lado, os pesos relativos são bastante significativos, pois mostram que o contexto EsCo de Ação desfavorece o aparecimento dos locativos como argumentos, o peso relativo é de apenas 0.16 , já este mesmo contexto favorece a função de satélite (peso relativo 0.84 ).

Os predicados em que os locativos aparecem mais freqüentemente como argumentos nos EsCos de Ação são aqueles que exigem um complemento locativo, como com os verbos ir, chegar, pôr, vir, dentre outros.

(95) “nossa eu adoru u lugar lá nossa eu vô eu vô lá na casa qui agora o meu irmão faleceu tamém agora faiz uns treis anu né?... qui eli faleceu agora ficô lá minha cunhada lá e a subrinhada... e: : : mas eu vô lá eu veju o lugar lá queu nasci nossa já parece qui... se eu pudesse vortá lá di novu otra veiz eu vortava..."

(FIL. Inq. IX: 16) 
(96) “Eu num posso ficá lá. Eu me insfucei, passei uns tempo parado quando cheguei aqui aí depois eu num tive muita liberdade lá na firma, no aeroporto, conheci gente, começaru me colocá em outro serviço”

(PP. Inq. XIV: 36)

(97) “... naquele tempo era pote num tinha firtro não punha lá com água meu Deus mais num aparecia ninguém pra me pedi água e eu ficava triste...”

(FIL. Inq. VIII: 48)

(98) “Não, até aqui nós temos a igreja de São Benedito, aqui do lado, ninguém vem aqui, na nossa comunidade, que eu saiba, que eu conhel, que eu tenho conhecimento, ninguém veio aqui na nossa comunidade, promovê qualqué coisa desse tipo"

(PP. Inq. XVI: 746)

Por outro lado, os locativos aparecem como satélites junto àqueles predicados que não exigem um complemento locativo, ou seja, o locativo pode ser perfeitamente retirado da oração sem causar danos ao entendimento desta.

(99) “... cum tar di zé cacu... é qui feiz aquela usina lá du machadu lá...nóis via a festa aí tava uma beleza alumiava só a rua (afora) né?"

(FIL. Inq. V: 210)

(100) “Vai chegá em São João Del Rei...dexá carro lá no estacionamento lá guardado...pegá o trenzinho...vai pra Tiradentis e.:"

(FIL. Inq. X: 7)

(101) “...e esse Fernando esse do meio ele é assim... que ele era assim... um pouco diferente do outro com cinco anos por exemplo chegava uma pessoa na minha casa... $e$ eu sempre deixava eles lá pra í numa feira num local perto aí quando chegava eu ia oferecê um café pra pessoa..."

(PP. Inq. XII: 88)

(102) “no aniversáriu dos amigo...elas pede biCHIga levá guaraNÁ pa com/pa: :. comemorá com os amiguinho lá...é sempre assim a creche é ótima...não tem do que recramá" 
Já quanto aos EsCos de Estado, o comportamento é bem diferente se comparado aos EsCos de Ação. Nota-se uma freqüência muito maior de locativos exercendo a função de Argumento de predicados em EsCos deste tipo. Num total de 297 ocorrências de Estado, apenas $20 \%$ delas traziam algum locativo como satélite de nível 2, enquanto nos $79 \%$ restantes, os locativos aparecem como argumentos de verbo. Tal fato já havia sido notado em Nogueira $(2003)^{20}$, quando a grande maioria dos locativos apareciam ao lado de verbos de Estado, segundo classificação de Borba (1990).

Quando olhamos para os pesos relativos referentes a este tipo de EsCo fica ainda mais clara a preferência dos locativos junto a EsCos de Estado, quando assumem a função de argumento. O peso relativo de 0.80 indica que os EsCos de Estado favorecem o uso dos locativos com a função de argumento e desfavorecem o uso com a função de satélite.

Neste tipo de EsCo, o locativo, enquanto dêitico, é qualificado, especificado. Neste tipo de predicado, o falante apenas enumera características para o locativo que está apontando. É Estado, pois não se dá nenhuma mudança [-din] e o $1^{\circ}$ argumento não tem controle sobre o EsCo.

(103) “Doc.le e cê leva onde ele no posto?

Inf. aqui num posto aqui: : em: ....tem uma igreja aqui que chama: .....até esqueci o nome da igreja...minha mãe pes/pega a cesta lá lá”

(PP. Inq. XVIII: 18)

(104)“Já agora já tem muitus anus já...já cabô u carru ...mai primeru aqui era seis sete carru ...passava aqui essas hora aqui ...mais cedu um bocadu..pa levá madera na estação..."

(FIL. Inq. III: 32)

(105) “: nói morava пu meiu du bairru i ela veiu dipoi na casa dum italianu... ficá lá... qui a iscola era lá...o: ..... a a professora () (veiu) de são luis.... uma professora MUIto boa demai nossa pa ensiná...."

(FIL. Inq. IX: 103)

Também encontramos locativos exercendo a função de satélite em EsCos de Estado. Porém, isso aconteceu em um contexto mais específico. Os locativos adverbiais

${ }^{20}$ Relatório de Iniciação Científica apresentado à FAPESP em 03/2003. Este estudo suscitou algumas das pdfMachine A pdf writer that produces quality PDF files with ease!

Produce quality PDF files in seconds and preserve the integrity of your original documents. Compatible across nearly all Windows platforms, simply open the document you want to convert, click "print", select the "Broadgun pdfMachine printer" and that's it! Get yours now! 
podem ser considerados satélites em um predicado de Estado quando, na maioria das vezes, aparecem na posição 4(Depois do Objeto). Ou seja, quando a característica que o falante deseja apontar não faz menção ao locativo, ele está na oração para localizar o EsCo designado por uma predicação em um mundo real ou imaginário e, assim, restringe o conteúdo de referentes potenciais da predicação à situação externa a que o falante tem em mente.

(106)... a vida lá primeiro num foi muito boa porque morei na casa do sogro muito tempo né?"

(FIL. Inq. VIII: 41)

(107) "acharo um:: tesouro ai ...e a gente::acredita que:: acho mesmo porque o dono da fazenda aqui...ele era encarregado de fazenda aí no Sul de Minas”

(FIL. Inq. X: 36)

(108) “... um rio que antes... quando eu cheguei aqui tomei muito banho porque ali era mato descia aquela água limpa eu lavava ropa... eu e os morador que não tinha água aqui... e a gente tomava banho naquela () a gente olhava via a areia... aquela coisa linda... e.: mais era uma coisa linda mesmo..."

(PP. Inq. XV: 628)

Nossa análise permitiu observar também a quase totalidade dos locativos como argumentos junto dos EsCos de Posição. Tal estado de coisa, como o próprio nome já diz, define a posição do falante, ou do falante em relação a outro EsCo. Assim, nada mais justo que o locativo ser complemento do predicado. Das 161 ocorrências deste tipo de EsCo, 159 apresentaram os advérbios aqui, aí, lá e ali como complementos do verbo, enquanto que em apenas 2 ocorrências os locativos exerceram a função de satélite junto deste tipo de EsCo.

O peso relativo 0.94 reforça essa constatação, pois indica a grande preferência dos locativos com a função de argumento junto a EsCos de Posição, ou seja, mostra-nos que este tipo de EsCo favorece em muito o aparecimento dos locativos com essa função.

Os predicados mais recorrentes quando o locativo apareceu como argumento junto a EsCo de Posição foram morar, ficar e estar. 
(109) “Cuntinua, é, eu peguei e cuntinuei aqui, ia pra lá e voltava, né, ia e voltava, desde cedo era isso. Um dia durmia, durmi, logo no dia que ela chegô, que ela veio de lá e eu tava aqui, aí, chegô na hora de durmí ela p6os a cabeça lá pos péis"

(PP. Inq. XIII: 112)

(110) “hoje é raro, por exemplo eu na minha posição hoje, na minha cidade eu não vinha mais pra São Paulo. Que a cidade evoluiu, é, eu tô aqui há douze anos, tem pessoas lá que nunca saiu de lá e tá bem. Tem carro novo, tem casa, eu tô aqui há douze anos e moro em área de prefeitura. São terreno de prefeitura, então o que acontece, tô batalhando, tô lutando, pra mim deixá alguma coisa pro meu filho"

(PP. Inq. XVII: 924)

(111) “eli ficava aqui i u fiiu deli ficava lá (eli dizia/) eli ficava nu corti... i i óia lá qui eli quiria () era trabaiadu purque ficava um lá i u otru ficava aqui otrus ficavam пи теіи...”

(FIL. Inq. I: 529)

(112) “... então agora semana retrasada eu fui lá ca: :. com um irmã minha qui: :. mora aqui até ela trabalha nu mercadu ela tá com ointenta i quatru anu i TRAbalha nu mercadu ainda na fera...então ela: :. eu: :. eu fui eu fui lá eu disse assim pra ela "ó eu queru i lá_nu fundão lá ondi nóis armava urupuca ..."

(FIL. Inq. IX: 48)

De todas as ocorrências de EsCo de Posição apenas duas mostraram os locativos como satélites. Nas duas vezes em que isso aconteceu há que se levar em conta o fato de o locativo estar depois do objeto, ou seja, ele não era o termo mais importante da oração, estava ali somente para localizar a predicação.

(113) "Eles tinha um boi aqui...o boi chamava::. como é que chamava o boi gente?"

(FIL. Inq. X: 144)

(114) “Os pião mexia....os pião te/ tinha umas corda aqui...pa/pra mexê com os boi....aí no... no... na fazenda aí..."

(FIL. Inq X: 178)

As duas orações trazem o predicado ter como núcleo. Assim, os constituintes (eles) 
exigidos pela semântica do predicado, são, assim, argumentos, enquanto o constituinte (aqui), apenas traz informação suplementar, e por isso é um satélite.

Assim:

Passado \{[ter (eles) (um boi)] (aqui)\}

Passado \{[ter (os peões) (umas cordas)] (aqui)\}

Por fim, falta-nos apresentar os resultados referentes ao EsCo Processo. Este tipo de EsCo caracteriza-se por ser do tipo [+din] e [-con]. Há uma mudança no EsCo, mas o $1^{\mathrm{o}}$ argumento não tem poder de controlar o que acontece.

Este foi o tipo de EsCo que menos apareceu em nosso corpus. Foram apenas 28 ocorrências. Desse total, em 13 ocorrências o locativo aparece como Argumento e em 15 como Satélites. Vemos, dessa forma, que os locativos apresentaram um comportamento similar ao que acontece quando estão juntos a predicados de Ação, mesmo quando observamos os pesos relativos, 0.94. Apesar de a freqüência entre argumentos e satélites ser bastante equilibrada, o peso relativo indica que este tipo de EsCo favorece o uso dos locativos com a função de satélite.

A seguir mostramos alguns exemplos dos locativos como argumentos de predicados de Processo.

(115)“Doc.2então...o senhor é nascido aqui?

Inf. eu sô na/ eu nasci lá pertu da serra”

(FIL. Inq. V: 2)

(116) "Nossa Ibituruna cabô ...que esse asfalto aí cabô...hoje tem essa bobera dessa carroça mai isso num vale nada”

(FIL. Inq. III: 26)

Nos exemplos abaixo aparecem os locativos exercendo sua função de satélites na oração.

(117) "Chegava a tremer esse boteco aí por exemplo...eles tinha que botá arame assim nas pratelera...pra segurá as garrada pa não caí no chão..."

(FIL. Inq. X: 48)

(118) “Num podi, é melhó dexá ondi tá. Num podi é igual o rapaiz aí, essa semana memu, qui choveu ali imbaxu, choveu aqui tamém, ná mai só qui lá imbaxu é pior u qui 
foi di máquina di lavá, televisão, e aquse morria trêis criança ali, si num fossi u rapaz qui tava aqui in cima, e faiz um serviçu aqui_imbaxu, as trêis criança tinha morridu”

(PP. Inq. XVIII: 374)

(119) "Caí do andaime. Quebrô coxa I quebrô aqui e quatru custela quebrada. Fui atendido no Sabóia"

(PP. Inq XVIII:231)

Os resultados da Tabela 3, confirmam que os locativos adverbiais aparecem, na mairoria dos dados, exercendo a função de Argumento. De um total de 961 ocorrências, $65 \%$ delas são de locativos com a função de Argumento, e apenas 34\% aparecem com a função de Satélite.

Ainda de acordo com os pesos relativos mostrados na tabela 3, podemos traçar contextos que favorecem o aparecimento dos locativos ora com a função de argumento, ora com a função de satélite. Assim, os EsCos de Ação e Processo desfavorecem a função de argumento, enquanto os EsCos de Posição e Estado mostraram-se com grande probabilidade de receberem os locativos com a esta função. Vemos assim, que há uma separação entre aqueles EsCos que apresentam o traço [+ din] e o traço [- din]. Os EsCos [+din] - Ação e Processo - privilegiam o aparecimento dos locativos enquanto satélites e os EsCos [-din] - Posição e Estado - favorecem o surgimento dos locativos enquanto argumentos de predicado.

Com isso, vemos que os locativos nem sempre exercem a função de satélites de predicados, ou adjuntos de verbos, como vimos no início desta dissertação, quando foram apontados alguns gramáticos que ainda afirmavam tal fato em seus estudos, como os de Cunha \& Cintra (2001) e Macambira (1974).

Por outro lado, isto vai ao encontro do que Luft (1994), Rocha Lima (1992), Mira Mateus (1989), Kury (1991) e Bechara (2001) afirmaram sobre o comportamento dos locativos junto a certos tipos de verbos. Para ilustrar como esses gramáticos viam o assunto vale voltar à explicação de Kury (1991) sobre os locativos. Tal explicação também nos ajuda a entender o aparecimento constante dos locativos junto a certos predicados. $\mathrm{O}$ autor admite que haja verbos transitivos adverbiais. Tradicionalmente, tais verbos são classificados como intransitivos, mas se entendermos a transitividade como a necessidade de um complemento, verbos como chegar, ir, partir, seguir, vir, voltar, estar. ficar. morar. etc quando pedem um complemento adverbial de lugar terão de ser 
vistos como transitivos, logo os adjuntos adverbiais de lugar assumirão o posto de argumentos de tais verbos e não de apenas adjuntos, uma vez que não constituirão mais meras informações acessórias. Ou seja, o complemento adverbial de lugar, que pode ser expresso por um advérbio, locução ou expressão adverbial, é o termo de valor circunstancial que completa a predicação de um verbo transitivo adverbial.

Também os funcionalistas apontam este comportamento dos locativos. Em 2.3 mostramos que Dik (1989:74) afirmou que os locativos poderiam ser entendidos como satélites de nível 2 ou ainda como argumentos. Para isso, ele ensina que "a general test, then, for distinguishing arguments from satellites is the following: a satellite can be left out without affecting the grammaticality or the meaning of the remaining construction, whereas leaving out an argument will either render the remainder ungrammatical or changes its semantics.” E termina por afirmar que tal critério não pode ser aplicado mecanicamente sem antes se levar em consideração o contexto em que o termo está inserido. (Cf. em 2.3, p.46)

O que fizemos, em nosso estudo, foi separar os predicados em tipos de EsCo e estabelecer uma classificação a partir disso e, assim, constatamos que junto a EsCo de Estado e, preferencialmente, de Posição, os locativos são na, maioria das vezes Argumentos.

Os contextos de uso podem ser especificados mais claramente se olharmos com atenção para a face sintática deste estudo. Pensamos ser necessário observar a posição que os locativos ocupam quando exercem a função de Argumento e quando exercem a função de Satélite de nível 2. Em alguns casos, este fato se mostrou bastante revelador. 


\subsection{POSIÇÃO DOS LOCATIVOS}

A tabela 4 nos mostra o resultado dos cálculos de freqüência e probabilidade (traduzida em pesos relativos) de uso dos locativos segundo a posição que eles ocupam na oração e a função que exercem.

\begin{tabular}{|c|c|c|c|c}
\hline & \multicolumn{2}{|c|}{ Argumento } & \multicolumn{2}{c}{ Satélite } \\
\hline Posição & Frequência & Peso relativo & Frequência & Peso relativo \\
\hline Incial (1) & $58 / 100=58 \%$ & 0.23 & $42 / 100=42 \%$ & 0.76 \\
\hline Antes do Verbo(2) & $31 / 54=57 \%$ & 0.20 & $23 / 54=43 \%$ & 0.79 \\
\hline $\begin{array}{c}\text { Depois do } \\
\text { Verbo(3) }\end{array}$ & $527 / 624=84 \%$ & 0.80 & $97 / 624=15 \%$ & 0.19 \\
\hline $\begin{array}{c}\text { Depois do } \\
\text { Objeto(4) }\end{array}$ & $10 / 183=5 \%$ & 0.02 & $173 / 183=94 \%$ & 0.97 \\
\hline Total & $626 / 961=65 \%$ & & & $335 / 961=34 \%$ \\
\hline
\end{tabular}

A grande maioria dos advérbios locativos aparece à direita dos predicados. De um total de 961 ocorrências, em 624 delas ou em $64 \%$ dos casos, os locativos estavam na posição 3, depois do verbo. Em seguida, a posição 4,depois do objeto, apareceu com 183 ocorrências ou $19 \%$ dos casos. Em posição incial ${ }^{21}$ ou P1, os locativos apareceram em $10 \%$ dos casos, com 100 ocorrências e, por último, a posição 2 , antes do verbo, com 54 ocorrências ou $5 \%$ do total.

Ainda é interessante notar, na tabela 4, que na posição depois do verbo ou posição 3 aparecem 84\% das occorências com os locativos exercendo a função de argumento. Já na posição 4, ou depois do objeto, aparecem os locativos em $94 \%$ das ocorrências com a função de satélite. Ou seja, quando o locativo é argumento, ele está preferencialmente ao lado do predicado, no entanto, se a função for de satélite, o locativo está mais distante deste. Como podemos observar nos exemplos (120) e (121):

${ }^{21}$ Devemos mencionar que na posição inicial (P1), neste primeiro momento, foram apenas considerados aqueles advérbios que assumiam uma função prototípica. Foram descartados os exemplos em que o 
(120) “mora tudu...mora em são paulo...mora em vorta redonda barra/barra mansa...só um que mora aqui...essa mesmo não mora aqui ela mora em são paulo"

(FIL. Inq.III:38)

(121) “...passou uns tempo...ele construiu a casa lá... aí casaro...”

(FIL. Inq. IV:65)

Nas posições 1 e 2, a diferença entre os subtotais é mínima, porém com um leve favorecimento para a função de argumento.

Embora nossos dados mostrem uma frequência maior de locativos com a função de argumento nas posições 1 e 2, quando olhamos para os pesos relativos vemos que essas duas posições favorem o aparecimento de locativos com a função de satélites -0.76 e 0.79 respectivamente. No entanto, os pesos relativos referentes às posições 3 e 4 confirmam nossas primeiras hipóteses. A posição 3 ou depois do verbo, tende a favorecer o aparecimento dos locativos com a função de argumento, (0.80). Já a posição 4 privilegia os locativos com a função de satélite, (0.97).

Assim, podemos esboçar possíveis contextos. Os locativos quando estão imediatamente à direita do predicado tendem a ser argumentos de verbo e quando ocupam posições mais periféricas, incial, depois do objeto, ou antes do verbo é grande a probabilidade de terem a função de satélites.

Num segundo momento, analisamos as posições que eles ocupam em função de cada um dos EsCos que explicitam.

\subsubsection{O EsCo DE AÇÃO}

\begin{tabular}{c|c|c} 
& Argumento & Satélite \\
\hline Posição & Frequência & Frequência \\
\hline $\mathbf{1}$ & $1 / 26=4 \%$ & $25 / 26=96 \%$ \\
\hline $\mathbf{2}$ & $1 / 12=8 \%$ & $11 / 12=92 \%$ \\
\hline $\mathbf{3}$ & $208 / 295=71 \%$ & $87 / 295=29 \%$ \\
\hline $\mathbf{4}$ & $9 / 142=6 \%$ & $133 / 142=94 \%$ \\
\hline Total & $219 / 475$ & $256 / 475$ \\
& Tabela 5: Frequência dos locativos que expressam EsCo de Ação e sua posição.
\end{tabular}


Vimos que de um total de 475 ocorrências de locativos em EsCos de Ação, 219 ocorrências apresentaram o locativo como Argumento, enquanto 256 ocorrências trouxeram os adverbias locativos como satélites. Esses números chamam a atenção por serem bem próximos. No entanto, se olharmos para as posições dos locativos no EsCo de Ação, quando assumem as funções de Argumentos e Satélites, veremos que são bem diferentes.

No EsCo de Ação, quando os locativos exercem a função de argumento, a posição preferencial é logo à direita do verbo, posição 3. Esta posição aparece em 208 ocorrências de locativos exercendo a função de argumento. No exemplo abaixo podemos observar o locativo aqui como argumento do predicado chegar.

(121) “... um rio que antes... quando eu cheguei aqui tomei muito banho porque ali era mato descia aquela água limpa eu lavava ropa... eu e os morador que não tinha água aqui... e a gente tomava banho naquela () a gente olhava via a areia... aquela coisa linda... e.: mais era uma coisa linda mesmo..."

(PP. Inq. XV: 627)

Já quando o locativo é satélite, a posição preferencial é a 4, ou depois do Objeto. Foram encontradas 133 ocorrências ou 94\% de locativos nesse contexto.

(122) “qui aqui num tinha...é num muitu tinha carru aqui purque aqui num tinha esse asfalto...ah....agora feiz esse asfalto aqui cabô tudu"

(FIL. Inq. XVIII: 3)

Também podemos perceber que no EsCo de Ação, as posições 1 e 2 são predominantemente ocupadas por locativos que têm a função de satélite correspondendo a 25 e 11 ocorrências respectivamente.

Vemos, assim, que a posição 3 privilegiou o aparecimento dos locativos em EsCos de Ação com a função de argumento, enquanto as demais posições 1, 2 e 4 mostraram-se favoráveis à função de satélites. 
4.5.2 O EsCo DE ESTADO

\begin{tabular}{|c|c|c} 
& Argumento & Satélite \\
\hline Posição & Frequência & Frequência \\
\hline $\mathbf{1}$ & $55 / 72=76 \%$ & $17 / 72=24 \%$ \\
\hline $\mathbf{2}$ & $26 / 37=70 \%$ & $11 / 37=30 \%$ \\
\hline $\mathbf{3}$ & $153 / 153=100 \%$ & 0 \\
\hline $\mathbf{4}$ & $1 / 35=3 \%$ & $34 / 35=97 \%$ \\
\hline Total & $235 / 297$ & $62 / 297$ \\
\hline & Tabela 6: Freqüência dos locativos que expressam EsCo de Estado e sua posição.
\end{tabular}

No EsCo de Estado, quando o locativo exerce a função de argumento, participando, dessa forma, da predicação nuclear, ele se encontra preferencialmente depois do verbo, como mostra a tabela acima, com totalidade de locativos ocupando a posição 3 com a função de argumento. No exemplo abaixo podemos observar o locativos nessa posição:

(123) "é... a canga é:....eu tenho ali ...é um pau cum quatru carrilha assim ó..."

(FIL. Inq. III: 21)

Os resultados de cálculos de frequência mostraram que em praticamente metade das ocorrências dos locativos junto a EsCos de Estado, eles estão à direita do verbo com função de argumento. Já quando são satélites, notamos que a posição preferencial é depois do objeto com 34 casos de um total 35 ocorrências de locativos em EsCos de Estado nesta posição, ou seja, $97 \%$ do total.

(124) "acharo um:: tesouro aí ...e a gente::acredita que:: acho mesmo porque o dono da fazenda aqui...ele era encarregado de fazenda aí no Sul de Minas”

(FIL. Inq. X: 36)

Também neste tipo de EsCo vemos que nas posições 1 e 2 aparece um número maior de locativos como argumentos. Na posição 1, em 76\% das ocorrências aparece o locativo com a função de argumento enquanto em $24 \%$ das casos eles são satélites. Comportamento similar têm os locativos na posição 2. Em 70\% dos casos, os locativos são argumentos e em apenas $30 \%$ dos casos eles são satélites. 
Assim, podemos observar, que nos EsCos de Estado, os locativos aparecem como argumentos nas posições 1,2 e 3 . Apenas na posição 4 ou depois do objeto vemos que os locativos têm a função de satélites.

Quando explicamos a face semântica dos locativos, observamos que eles aparecem mais como argumentos em EsCos de Estado e em quase todos os EsCos de Posição. A posição preferida pelos locativos quando exercem a função de argumento é logo depois do verbo. Tal fato ainda é mais evidente quando se trata de EsCos de Posição, como podemos ver a seguir.

\subsubsection{O EsCo DE POSIÇÃO}

\begin{tabular}{c|c|c} 
& Argumento & Satélite \\
\hline Posição & Frequência & Frequência \\
\hline $\mathbf{1}$ & $2 / 2=100 \%$ & 0 \\
\hline $\mathbf{2}$ & $3 / 3=100 \%$ & 0 \\
\hline $\mathbf{3}$ & $154 / 154=100 \%$ & 0 \\
\hline $\mathbf{4}$ & 0 & $2 / 2=100 \%$ \\
\hline Total & $159 / 161=99 \%$ & $2 / 161=1 \%$ \\
\hline \multicolumn{2}{|c|}{ Tabela 7: Freqüência dos locativos que expressam EsCo de Posição e seu lugar na oração . }
\end{tabular}

Chama nossa atenção a totalidade dos locativos exercendo a função de argumento nas posições 1, 2 e 3, pois esperávamos esta totalidade apenas na posição depois do verbo. No entanto, podemos observar que neste tipo de EsCo a função argumento é predominante inclusive nas duas primeiras posições.

Observamos também que de um total de 161 ocorrências de locativo junto a EsCos de Posição, em 154 delas, o locativo está logo à direita do predicado. Ou seja, neste EsCo o contexto para o aparecimento do locativo é bem definido - quando exerce a função de argumento, ele é usado logo depois do predicado, como vemos nos exemplos (125) e (126).

(125) “Doc.1cê tem parentes lá na bahia marcia?

\section{Inf. minha mãe meu pai moram lá...meus tios tias tudu mora lá"}

(PP. Inq. XX: 73) 
(126) “ói morava di agregadu purque aondi eu morava lá só era dus otru era du seu vergueru $i$ dus otru tudu né? fiquei lá muitu tempu...antigu us fazenderu tinha aqueles colônia na fazenda né?"

(FIL. Inq. V: 83)

Além disso, a Tabela 7 também confirma nossas primeiras hipóteses de que os locativos junto de EsCos de Posição seriam, na maioria dos casos, argumentos de verbo e ocupariam a posição 3 .

\subsubsection{O EsCo DE PROCESSO}

\begin{tabular}{c|c|c} 
& Argumento & Satélite \\
\hline Posição & Frequência & Frequência \\
\hline $\mathbf{1}$ & 0 & 0 \\
\hline $\mathbf{2}$ & $1 / 2=50 \%$ & $1 / 2=50 \%$ \\
\hline $\mathbf{3}$ & $12 / 22=55 \%$ & $10 / 22=45 \%$ \\
\hline $\mathbf{4}$ & 0 & $4 / 4=100 \%$ \\
\hline Total & $13 / 28=46 \%$ & $15 / 28=54 \%$ \\
\hline & \multicolumn{2}{|c|}{ Tabela 8: Freqüência dos locativos que expressam EsCo de Processo e sua posição. }
\end{tabular}

Vemos que na posição 1, não houve ocorrência de locativo junto a este EsCo e que na posição 2 o número é igual para as duas funções. A posição em que mais apareceram tanto como Argumentos quanto como Satélites foi depois do verbo. Os resultados apontam para ser esta a posição preferida nesse tipo de EsCo.

No exemplo (127) observamos o locativo como argumento do predicado alagar e ocupando a posição 3 e no exemplo (128) notamos o locativo também na posição 3, só que agora na função de satélite de predicado.

(127) "De veiz im quandu alaga aqui tudinhu ... aqui atrais... agora aqui num alaga mais não [ inint] agora esse otro ladu aqui num alaga"

(PP. Inq XIII: 308)

(128) “Doc. e o senhor nasceu onde?

\section{Inf. Eu nasci aqui”}

(FIL. Inq. III: 2) 
Chama a atenção a posição 4 , em que apareceram apenas locativos exercendo a função de satélite.

(129) “tremeu a terra basTANti aqui... mexia tudo nas prateteleira..."

(FIL. Inq. III:65)

Os dados não nos autorizam a estabelecer uma regra para a posição dos locativos quando forem argumentos ou satélites em EsCos de Processo. Depende exclusivamente do verbo e do contexto de uso no qual está inserido tal constituinte. Mas se recorrermos aos pesos relativos apresentados na Tabela 2 deste capítulo, veremos que este tipo de EsCo favorece o aparecimento de locativos com a função de satélite.

Em síntese, entendemos que junto a predicados que exigem um locativo como argumento, como acontece preferencialmente nos EsCos de Posição e Estado os locativos ficam logo à direita do verbo, constituindo uma predicação nuclear. Já quando este locativo é um satélite, na maioria das vezes, aparecerá depois do objeto. Nesses casos, a predicação passa a ser denominada de predicação estendida, ou seja, as posições argumentais, ao lado do predicado, já foram ocupadas e o satélites são termos que são colocados junto ao predicado para trazer informações que não são essencias, mas sim opcionais e, por isso, mantêm-se distantes do predicado.

\subsection{TROCA DE POSIÇÃO}

Partimos do pressuposto, em nosso estudo, de que quando os locativos assumissem a função de argumento seria mais difícil o deslocamento do termo para outra posição na oração, ao contrário dos satélites, que poderiam ser facilmente trocados de posição, por apresentarem um comportamento mais livre, conforme visto em DIK et al. (1990). Os autores explicaram que satélites $\sigma_{1}$ estão mais intimamente relacionados ao predicado do que os satélites $\sigma_{2}$, que assumem um comportamento mais solto. Além disso, eles são também muito mais livres para ocorrer tanto no início como no final da oração, diferentemente dos argumentos que possuem uma relação mais estreita com o predicado, constituindo a predicação nuclear.

Nossos dados mostraram, no entanto, que os locativos são passíveis de troca, quando são argumentos e quando têm a função de satélite. 


\begin{tabular}{c|c|c|c|c} 
& \multicolumn{2}{|c|}{ Argumento } & \multicolumn{2}{c}{ Satélite } \\
\hline Troca & Frequência & Peso relativo & Frequência & Peso relativo \\
\hline Sim & $510 / 834=61 \%$ & 0.43 & $324 / 834=38 \%$ & 0.56 \\
\hline Não & $116 / 127=91 \%$ & 0.85 & $11 / 127=8 \%$ & 0.14 \\
\hline Total & $626 / 961$ & & $335 / 961$ & \\
\hline \multicolumn{2}{|c|}{} & & \multicolumn{3}{|c}{ Tabela 9: Deslocamento dos locativos na oração. }
\end{tabular}

Na tabela acima podemos ver que das 961 ocorrências de locativos analisadas, em 510 delas o locativo tem a função de argumento e a troca pôde ser feita. O número de satélites que puderam sofrer o deslocamento é ainda mais expressivo, de 335 ocorrências de satélites encontradas, em 324 delas a troca foi realizada. Isto já era previsível, uma vez que sabíamos que os satélites, de modo geral, sejam eles pertencentes a quaisquer níveis da cláusula, possuem um comportamento mais livre na oração

Devemos observar ainda que das 127 ocorrências de locativos que não puderam ser trocados na oração, 116 delas ou $91 \%$ tem a função de argumento. Ou seja, mesmo com uma alta frequência de locativos que sofreram a troca quando argumentos, há de se levar em consideração a alta porcentagem de locativos argumentos que não puderam sofrer o deslocamento.

A análise dos pesos relativos nos mostram que o contexto argumento de predicado desfavorece a troca de posição - 0.43 , enquanto a função de satélite favorece o deslocamento - 0.56. Apesar de o locativo apresentar uma alta frequência de deslocamento quando assume a função argumento, os pesos relativos nos indicaram que essa função desfavorece a mudança de lugar do locativo na oração e a função satélite, por ser composta de termos opcionais e que não têm ligação estreita com o predicado, favorece a troca de posição.

Isso confirma Dik et al. (1990) que explicam que quanto mais um termo assumir a função de argumento menor será a mobilidade deste na oração. Já quando este termo ocupar uma posição mais periférica, mais facilmente será permitida a troca de posição.

A próxima tabela mostra o cruzamento entre a freqüência de troca em cada uma das posições analisadas. 


\begin{tabular}{c|c|c|c|c|c|}
\multirow{2}{*}{} & \multicolumn{2}{|c|}{ Sim } & \multicolumn{2}{c|}{ Não } & \\
\hline Posição & Argumento & Satélite & Argumento & Satélite & Total \\
\hline $\mathbf{1}$ & $53 / 94=56 \%$ & $41 / 94=44 \%$ & $5 / 6=\mathbf{8 3} \%$ & $1 / 6=17 \%$ & 100 \\
\hline $\mathbf{2}$ & $25 / 48=52 \%$ & $23 / 48=48 \%$ & $6 / 6=\mathbf{1 0 0} \%$ & 0 & 54 \\
\hline $\mathbf{3}$ & $425 / 510=\mathbf{8 2 \%}$ & $91 / 510=18 \%$ & $102 / 108=\mathbf{9 4 \%}$ & $6 / 108=6 \%$ & 624 \\
\hline $\mathbf{4}$ & $7 / 176=4 \%$ & $169 / 176=\mathbf{9 6 \%}$ & $3 / 7=43 \%$ & $4 / 7=57 \%$ & 183 \\
\hline Total & $510 \quad$ & 324 & 116 & 11 & 961 \\
\multicolumn{2}{|c|}{ Tabela 10: Freqüência do locativo segundo sua posição e possibilidade de deslocamento. }
\end{tabular}

$\mathrm{Na}$ tabela acima, chamamos a atenção para os resultados mais expressivos. Podemos perceber que quando a troca foi permitida, ela ocorreu mais vezes com os locativos com a função de argumento, $82 \%$ dos casos. Vê-se assim, que mesmo sendo argumento e ocupando a posição logo à direita do predicado, o locativo ainda possui grande mobilidade. Já quando os locativos assumiam a função de satélite, a posição em que mais houve a troca foi a posição 4, ou depois do objeto, com $91 \%$ dos casos. Este número é perfeitamente compreensível, uma vez que os locativos enquanto satélites são opcionais e podem aparecer em qualquer lugar da oração.

Devemos relembrar ao leitor que quando a troca foi efetuada não houve prejuízo semântico para a oração, apenas um efeito discursivo diferente, já que se mudou, mesmo que sem prejuízo ao entendimento desta, a curva entonacional da oração.

Vimos na tabela 9 que os locativos aqui, ali, aí e lá, na maioria das vezes, podem deslocar-se no eixo sintagmático. Se olharmos para a tabela veremos que a não troca registrou uma alta freqüência nas posições 1,2 e 3 quando o locativo tem a função de argumento. Na posição inicial ou P1, 83\% dos locativos argumento não puderam ser trocados de lugar na oração, na posição P2 ou antes do verbo, 100\% dos casos de locativos como argumentos não foram trocados, e na posição depois do verbo ou P3, 94\% dos casos de locativos como argumentos não sofreram o deslocamento. Quando satélites, foram poucos os casos em que os locativos não tiveram mobilidade na oração, vemos que em $96 \%$ dos casos o locativo com a função de satélite pôde ser deslocado.

É notável o fato de a posição depois do verbo ou posição 3 ser uma das que mais possibilitaram a troca e também ser uma das que mais restringiram a troca. No entanto, devemos levar em consideração os pesos relativos apresentados na Tabela 9 que nos mostraram que a posição 3 desfavorece a troca de lugar do locativo. 
Assim, observamos que quando os locativos são argumentos, a mudança de posição não é tão possível como quando os locativos assumem a função de satélites. Ou seja, a característica dos locativos adverbiais de possuírem grande mobilidade na oração só é completamente cumprida quando estes têm a função de satélite.

\subsection{PLANOS NARRATIVOS}

Em 4.2.4 mostramos que os satélites de nível 2 e os argumentos pertencem ao nível representacional, conforme classificação proposta por Hengeveld (1989 apud NEVES, 1997). Também vimos que os locativos nas narrativas ora apareciam em um $1^{\circ}$ plano, ora apareciam junto a informações secundárias. Hopper (Cf. HOPPER, 1979, 1982; HOPPER e THOMPSON, 1980 apud RODRIGUES et al. 1996) ensinou que o texto narrativo pode ser dividido em dois planos - narrativo e comentário. O plano narrativo é aquele que carreia as informações principais e que normalmente apresenta verbos no pretérito perfeito em português. Já o plano comentário é aquele que traz as informações secundárias, aquelas que de fato constituem algum comentário sobre o que foi dito no plano narrativo, e geralmente os verbos estão no pretérito imperfeito em português.

Visto isso e com base em resultados apresentados em Nogueira (2003) partimos da hipótese de que os locativos junto a EsCos de Estado estariam com mais freqüência no plano Comentário e os locativos junto a EsCos de Ação apareceriam com mais recorrência no plano Narrativo.

$\mathrm{Na}$ tabela a seguir vemos que o o tipo de texto Comentário apereceu mais vezes que o texto Narrativo. De um total de 961 ocorrências analisadas em nosso corpus, 538 delas aparecem constituindo o plano comentário, e 423 constituem o plano narrativo.

\begin{tabular}{|c|c|c|c|c|}
\hline & \multicolumn{2}{|c|}{ Argumento } & \multicolumn{2}{|c|}{ Satélite } \\
\hline Texto & Frequência & Peso relativo & Frequência & Peso relativo \\
\hline Comentário & $353 / 538=65 \%$ & 0.42 & $185 / 538=34 \%$ & 0.57 \\
\hline Narrativo & $273 / 423=64 \%$ & 0.59 & $150 / 423=35 \%$ & 0.40 \\
\hline Total & $626 / 961=65 \%$ & & $335 / 961=34 \%$ & \\
\hline
\end{tabular}

Ainda de acordo com a tabela, é possível observar que nos dois planos os locativos 
respectivamente. Também com os locativos como satélites a proporção foi bem parecida, no Comentário 34\% das ocorrências mostram os locativos como satélite e no Narrativo $35 \%$ das ocorrências apresentam os locativos com a função opcional na oração.

No entanto, se olharmos para os pesos relativos veremos que há um ligeiro favorecimento (0.57) ao aparecimento de locativos com a função de satélite em textos do tipo comentário. Já o plano narrativo, favorece, ainda que de maneira discreta (0.59), o aparecimento de locativos com a função argumento.

$\mathrm{Na}$ tabela a seguir vemos como os EsCos estão divididos de acordo com estes dois planos.

\begin{tabular}{c|c|c|c|c} 
& Ação & Posição & Estado & Processo \\
\hline Comentário & $207 / 538=43 \%$ & $110 / 538=68 \%$ & $217 / 538=73 \%$ & $4 / 538=15 \%$ \\
\hline Narrativo & $268 / 423=57 \%$ & $51 / 423=32 \%$ & $80 / 423=27 \%$ & $24 / 423=85 \%$ \\
\hline Total & $475 / 961$ & $161 / 961$ & $297 / 961$ & $28 / 961$ \\
\cline { 3 - 4 } & \multicolumn{3}{|c|}{ Tabela 12: Uso dos locativos segundo os EsCos e os planos narrativos. }
\end{tabular}

Em primeiro lugar, os resultados da tabela 11 confirmam nossa hipótese de que o EsCo de Ação aparecem principalmente no $1^{\circ}$ plano - Narrativo, e que o EsCo de Estado está mais relacionado com o $2^{\circ}$ plano - Comentário.

Por outro lado, de um total de 475 ocorrências do locativo junto a predicados de ação, 207 apareceram em texto Comentário e 268 em texto Narrativo. Os locativos junto a predicados de Ação aparecem em 57\% das ocorrências em texto Narrativo e com 43\% das ocorrências em texto Comentário. Hopper (1972 e 1980 apud RODRIGUES et. al. 1996) explica que em virtude de as frases de $1^{\circ}$ plano indicarem eventos discretos de uma narrativa seus verbos tendem a ser mais pontuais, mais do que durativos ou interativos. Em outras palavras, os EsCos de ação aparecem mais em orações que pertecem ao plano narrativo e que se relacionam com o perfectivo, pois estes carreiam eventos mais dinâmicos, com noções de movimento, ação e transformação. Já os EsCos de Estado estão mais relacionados com o plano Comentário e por conseguinte com o imperfectivo, pois se referem a estados e situações descritivas. Observamos na tabela que de um total de 297 ocorrências de locativo junto a predicados de Estado, 217 ou $73 \%$ de ocorrências estão inseridas no $2^{\circ}$ plano - Comentário, e apenas 80 ou $27 \%$ de ocorrências estão no plano narrativo, ou $1^{\circ}$ plano. 
Nos exemplo (130) observamos locativos ou expresões locativas em um texto Narrativo com EsCos de Ação e Processo.

(130) "QUAse a mesma história dela ((ri))...eu nasci na bahi: :.a e...fiquei na bahia até: :.... ((voz de criança)) os dezesseis anos depois dos dezesseis anos vim pra qui...aí cheguei aqui: :. com dezessete arrumei o pai desses filhos..."

( PP. Inq. XX:7)

Já nos exemplos a seguir (131) e (132) vemos que as últimas expressões em destaque de cada exemplo pertecem ao grupo daquelas que tecem comentários, são EsCos de Estado, estão no presente e no pretérito imperfeito respectivamente. As primeiras expressões em destaque de cada exemplo pertecem ao texto narrativo, são EsCos de Ação e estão no pretérito perfeito.

(131) “...trupeçô lá e veio incima...aí eu incustei lá na porta eu digu 'na hora qui ela vimque eu sei qui ela vem eu façu di conta qui cai e metu os pé nela' ...qui eu tenhu essa perna aqui qui é defeituosa...sô acidentadu pur issu..."

(PP. Inq. VIII:187)

(132) “... um rio que antes... quando eu cheguei aqui tomei muito banho porque ali era mato descia aquela água limpa eu lavava ropa..."

(PP. Inq. XV:627)

Com relação aos predicados de Posição, vemos que de um total de 161 ocorrências, 110 delas apareceram inseridas em texto Comentário e apenas 51 em texto Narrativo. No exemplo abaixo vemos uma ocorrência de locativo junto a um EsCo de Posição e constituindo um Comentário.

(133) “... esse Pacheco trabalhô muito aqui... ... e pó isso que eu gosto desse moço esse neto dele que mora ai"

(FIL. Inq. VIII: 83)

Já quanto ao EsCo de processo, das 28 ocorrências, 24 estão inseridas em texto narrativo e somente 4 ou $15 \%$ em texto comentário. No exemplo a seguir podemos observar um locativo junto a um EsCo de Processo e constituindo um texto Narrativo. 
(134) "mais a gente aprendeu apenas pra vivê né? e:: me serviu muito... meu marido adoeceu lá na roça... me valeu que eu sabia escrevê um bocadinho..."

(FIL. Inq.VIII: 90)

Os resultados sugerem que os locativos são mais recorrentes no Comentário quando estão junto de EsCos de Posição e Estado, pois nestes tipos de EsCos existem os predicados que indicam menor dinamismo e que estão no imperfeito. Já os locativos que estão em EsCos de Ação e Processo, relacionam-se com o texto Narrativo, uma vez que neste tipo de texto os verbos são mais dinâmicos e mostram alguma mudança ou transformação, logo estão relacionados também com o perfeito.

Mais uma vez o traço [dinamismo] foi decisivo para a análise. Os EsCos [-din] Posição e Estado favorecem a presença de locativos no plano comentário. Já os EsCos Ação e Processo que apresentam o traço [+ din] privilegiam o aparecimento de locativos no plano narrativo.

\subsection{AÍ NA POSIÇÃO P1}

O uso altamente freqüente de aí em posição inicial levou-nos a observar que esta posição (P1) é a preferida pelo advérbio de lugar aí quando este assume a função de marcador discursivo ou de conector de texto. Chamou-nos a atenção a quantidade de vezes que este advérbio assumiu tal função. Encontramos um total de 443 ocorrências deste tipo de advérbio funcionando como conector de texto, contra 84 ocorrências com a função locativa prototípica.

Vimos que a posição em início de turno do advérbio aí faz com que ele, na maioria dos casos, perca sua função locativa e assuma um valor de conector textual. Quando o advérbio aí aparece no interior da unidade discursiva com pausa anterior a ele, o advérbio funciona como conector de porções de texto, cuja frase nuclear apresenta verbos com as mesmas marcas de flexão modo - temporal . Neste caso, trata-se de um trecho narrativo, cujos eventos são amarrados em sequência pelo advérbio aí.

(135) “...aí ela foi tamém ...aí intendeu né? ela foi pra lá cumeçô [ inint ] assim... daí amanhã cedinhu na boa lá... ficamu naquela ali ... passanu passanu toda a confusão passô... aí um dia mi chamô né? ah si quisé I im casa tal ... aí eu falei tudo bem mai dexá di saí eu num vô... vô pá rua mais dexá di saí num vô ...aí tudu bem durmí cum 
ela...ficamu lá à vuntadi ...aí quando foi nu otro dia mais ou menu uma hora dessa...mais ou menu umas oito hora era oito hora ....aí chegô um colega meu ...chegô um colega meu ...cheguei abri uma cerveja tomamo ...aí eu peguei abri um cerveja da minha...nóis tomamu abri uma da minha..."

(PP. Inq. XIII:117)

(136) “...aí chego aquele negrão aqui em São Tiago todo importante... de chapelão de bota de espora...e pergunto... tinha um turco que chamava Antonho turco ... onde mora José Gabé Júnior? ... aí o turco respondeu...até onte morava ali...naquele lugar que chama pavuna...o/o/onte foi todo mundo pro cemitério...e essa pavuna tem aí até hoje...o ligar chamado pavuna..."

(FIL. Inq. IV: 14)

Podemos notar nos exemplos apresentados que a função de conector de texto do advérbio aí pode estar relacionada com a sua distribuição no turno. Quando a palavra aí aparece como conector de texto é, na maioria da vezes, em início de turno, ou no interior de uma unidade discursiva com pausas anteriores a ela.

Para Votre (1997) a forma aí está em um processo adiantado de gramaticalização e que recebe o nome de desgramaticalização, que consiste na perda total da transparência. As formas associam-se a novos significados, progressivamente mais abstratos, partindo da noção de espaço, podendo passar ou não pela noção de tempo, e desembocando na categoria mais abstrata do texto, ou seja, espaço $>$ tempo $>$ texto/discurso.

Votre (1997) também faz menção à "unidirecionalidade da mudança", no sentido do concreto > abstrato. Esse conceito pode ser aplicado à forma aí , que de advérbio de lugar, passa a advérbio de tempo, em alguns contextos, e também pode funcionar como marcador discursivo. A forma se associa a novos significados, progressivamente mais abstratos. No corpus estudado, tais fases podem ser surpreendidas em sincronia.

(137) “...queria que ela arumasse um marido melhor pra ela qui: .....ajudasse ela e os fiio dela...só atraPAlha...aí agora ele nu mora mais aí mora em santo amaro mais sempre ele tá aí...vem vê as criança...depois vai embora di novu...e ela...agora tá no hospital...vô buscá a minininha dela...dorme aqui em casa mais a: :....mais a gente...e os otros dois dorme pra lá ca minha mãe...tem que dividí ((risos)) um fica com um um fica com outro"

(PP. Inq. XIII: 362) 
No exemplo (137) a forma aí aparece primeiramente com um valor de tempo reforçando a idéia de tempo da forma agora. Nos outros dois exemplos aí assume o valor prototípico de advérbio de lugar junto a EsCos de Posição. Já no exemplo (138), retirado do mesmo inquérito, podemos notar que a forma aí é essencialmente concetora de texto.

(138) “...aí ela fica chorando que ela nu...que ela nu tem o pai mas ela tem pai...mas ela nu sabe que tem pai ela chora...aí a: :: m/a mãe dela que ela acha/ que ela gosta/ que ela chama de mãe adora ela toda pessoa qui felque faiz algum mau pra ela ela já deFENdi...”

(PP. Inq. XIII:427)

Para Martelotta (1994), o que se dá com aí pode ser compreendido pela seguinte sequência referente ao processo de gramaticalização desse operador.

\section{Aí Dêitico}

$\downarrow$

Aí Anafórico

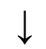

Aí Sequencial

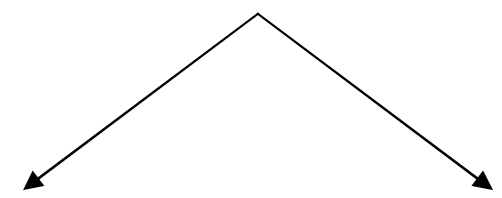

Aí introdutor de informações livres Aí conclusivo

Para o autor,

esta seqüência demosntra que o operador aí cumpre todo o processo de gramaticalização espaço (tempo) > texto em língua portuguesa atual. Esta trajetória de gramaticalização tem seu ponto de partida no uso dêitico espacial, que, por metáfora gera o uso anafórico que, por pressão de informatividade no sentido de Traugott \& Konig (1991:194), gera o uso seqüencial. Este uso em contexto sequencial origina duas camadas distintas: aí introduzindo informações novas, por 
pressão de informatividade e aí conclusivo ${ }^{22}$ pela coocorrência dos mecanismos de metáfora espaço (tempo) > texto e de pressão de informatividade. (1994: 109)

Vemos que a noção de tempo pertencente ao advérbio aí é importante. Essa noção de tempo pode ser mais bem entendida se relacionarmos o advérbio aí ao advérbio temporal então. Essa possibilidade foi considerada por Risso (1996). A autora afirma que o articulador discursivo então e o advérbio aí fazem parte do grupo dos marcadores conversacionais, podendo ser orientados para o texto ou para o falante. Risso (1996) vê que assim como o advérbio aí, então também mostra um grau maior de distanciamento entre as propriedades gramaticais do advérbio temporal sentencial e o marcador discusivo. Esse afastamento se deve à interferência de fatos discursivos e pragmáticos em contexto de dialogização. Ou seja, em estruturas ideacionais atesta-se o maior uso de então como advérbio temporal, sua função prototípica, e em estruturas interpessoais o uso do marcador discursivo despido de suas funções gramaticais.

Em alguns contextos, aí pode assumir o lugar de então ou o advérbio de tempo pode substituir o lugar do conector de texto aí. Em nosso corpus as formas apareceram juntas em alguns momentos, acentuando, dessa forma, o caráter de conector de texto das duas formas.

(139) “os marido virem pra São Paulo trabalhá pra ganhá um dinheirinho pra mandá pras esposa aí as esposa ficava lá cuidando das roças ou dos filhos e o marido vem aqui pra tabalhá ... então aí ele sempre arruma uma crian/ uma menina pra ficá cuidando das crianças ou também olha o arroz pra ela... uma coisa assim... e aí eu comecei a trabalhá”

(PP. Inq. XII: 257)

(140) “... Mairiporã tem uma capacidade pra dez mil ... pessoas né são dois auditórios... então aí lá... a pessoa faz uma declaração em publico né que ela está se dedicando a sua vida a Deus no dia ela dá ela dá o nome né aqui na congregação local ela dá o nome é onde são feitas essas consideração que eu acabei de falá"

(PP. Inq. XII: 442) 
Chamou-nos a atenção ainda o uso do advérbio aí junto do advérbio de tempo depois. Os dois juntos também assumem o mesmo caráter de conector de texto, dando seqüência ao que está sendo narrado, semelhante ao que vimos com então.

(141) “ isso... pra tá trabalhando e pra... né... salário mais num foi possível... aí depois... ele... ele saía inda com os colega... fazê ficha em loja em tudo..."

( PP.Inq.XIX:269)

(142) “... eu tenho uma vizinha minha só que ela estuda na escola de baixo aí as vezes eu venho com ela até a escola aí depois eu subo aqui o asfalto..."

(PP. Inq. XI: 335)

(143) "Ô Raimundu vem imbora fala pra ele vim bora que o lugá dele num é aí num sei o quê... [inint] eu digu... mai aqui é melhó pra mim vivê eu tenho a minha vida né?... aí depois acunteceu um fuchico entre essa mulhé qui tá cumigo hoje... ela disse ela qui eu tinha coisa cum essa mulhé antes e eu num tinha nada cum ela... aí depois quando ela chegô aí enchero a cabeça dela ...enchero aí..."

(PP. Inq.XIII:54)

Os dados analisados permitiram-nos constatar que as formas aí, então e depois possuem comportamento bastante parecido quando assumem a função de sequenciador de texto, podendo até combinar-se entre si, como vimos com então aí e aí depois.

Por tudo isso, vemos que o advérbio aí diferentemente das outras formas aqui, ali e lá assume outras funções discursivas associando-se a termos que denotam tempo. Notamos ainda que em alguns contextos, este advérbio apresenta processo avançado de disvursivização, e o início de turno ou posição P1 constitui posição favorecedora deste processo. 


\section{CONSIDERAÇÕES FINAIS}

Nesta pesquisa buscamos analisar de um ponto vista sincrônico e quantitativo, as funções que os locativos aqui, aí, ali e lá exercem na oração e no texto. Para isso, trabalhamos com a variedade do português popular falado, mais especificamente com o material do Projeto Filologia Bandeirante e do material do Banco de Dados do Português Popular Falado na Cidade de São Paulo.

O capítulo 1 compreendeu a apresentação dos pressupostos teórico-metodológicos adotados, baseados na Gramática Funcional de Simon Dik (1989) e na Sociolingüística Variacionista.

Nele discorremos principalmente sobre os princípios básicos do Funcionalismo, sobre o modelo de análise da predicação e sobre os aspectos importantes para uma tipologia semântica dos EsCos, que foram noções de suma importância para o estabelecimento dos contextos de uso dos locativos enquanto argumentos e satélites na oração.

Vimos que o Funcionalismo considera que a linguagem se define inteiramente como um instrumento de interação social empregado (por seres humanos) com o propósito de estabelecer a comunicação entre os interlocutores. As expressões lingüísticas são estruturadas no sentido de que são regidas por regras. Assim, tanto as regras sociais como as regras lingüísticas estão subjacente à interação verbal. As regras lingüísticas devem ser instrumentais com relação aos objetivos comunicativos da interação verbal. Além disso, aprendemos que para os funcionalistas a pragmática é o quadro dentro do qual a semântica e a sintaxe devem ser estudadas, as prioridades vão da pragmática à sintaxe, via semântica.

No modelo de análise da oração foi sobretudo importante a análise proposta por Dik (1989) da predicação subjacente da oração. Nela vimos noções como termos, predicado, argumentos, satélites e operadores, que constituem um EsCo passível de acontecer em um determinado mundo, seja ele real ou imaginário.Os EsCos podem ser divididos de acordo com alguns parâmetros distintivos (dinamismo, telicidade, momentaneidade, controle, experiência). Para o nosso trabalho foram significativos os parâmetros Dinamismo e Controle, que combinados formavam os EsCos de Ação, Posição, Estado e Processo. Essa tipologia norteou o estabelecimento dos contextos de uso dos locativos sugeridos em nosso trabalho. 
Também neste capítulo observamos noções de correlação e quantificação, que nos serviram de ferramenta para a análise dos dados. Nossa pesquisa não trata de um caso de variação prototípico, mas o modelo de análise da Sociolingüística Variacionista nos mostrou a possibilidade de se correlacionar o uso dos locativos às suas condições de produção. O modelo também nos forneceu um percurso de análise estatística. Valemonos de uma estatística descritiva e de inferências, que nos permitiu chegar a conclusões sobre o uso dos locativos partindo da análise dos dados recolhidos em 20 inquéritos, que foram representativos da variedade de Português Popular Falado.

No capítulo 2, apresentamos resenha de estudos que tratam dos advérbios locativos no português do Brasil. Nele mostramos como os locativos adverbiais são vistos na Gramática Tradicional, como são tratados pelos lingüistas, bem como a abordagem funcional de Dik (1989) e Dik et al. (1990).

Quanto às gramáticas tradicionais, vimos que algumas já consideram os locativos como argumentos na oração, como Luft (1994), Rocha Lima (1992), Kury (1991), Bechara (2001), Back \& Mattos (1972) e Said Ali (1964). Estes autores apesar da nomenclatura variada, falam de duas funções sintáticas que os locativos podem exercer adjunto ou complemento.

Os lingüistas também compreendem que os locativos não podem permanecer na mesma classe gramatical que os demais advérbios, uma vez que desempenham funções como de pronomes e também podem ser argumentos de verbo, assim como assumir funções discursivas, como a de conector de texto.

Por fim, a leitura de textos sobre a Gramática Funcional possibilitou-nos o estabelecimentos de alguns dos fatores utilizados para se especificar os contextos de uso dos locativos com as funções de argumento e satélite. Dik (1989) afirma que os argumentos estão ao lado do predicado, ocupando assim uma posição mais central, enquanto os satélites estão mais a periferia na oração. Complementando os ensinamentos de Dik (1989), Hengeveld (1997) explica que os advérbios organizam-se em uma sentença de acordo com a localização do predicado central dessa sentença e que os satélites de nível 2 possuem um comportamento muito mais livre na oração. Essas observações levaram-nos a observar a posição dos locativos na oração, estabelecendo, assim, quatro posições - inicial, antes do verbo, depois do verbo e depois do objeto.

Hengeveld (1997) ressalta ainda que os advérbios com componentes dêiticos, como os satélites de nível 2, possuem um comportamento mais solto na oração do que os 
uma posição mais central na sentença, não possuem grande mobilidade na oração. Já os satélites de nível 2 podem aparecer tanto no início quanto no final da oração. Visto isso, decidimos verificar se de fato os locativos manteriam essa característica mesmo quando fossem argumentos da oração, ou se quando assumissem essa função ficariam mais presos ao predicado como os satélites de nível 1.

A última variável considerada foi escolhida levando-se em consideração explicações de Hengeveld (1989 apud NEVES, 1997) sobre um modelo de análise da "cláusula" em dois níveis baseado em uma integração dos funcionalismos da escola da Holanda com a de Halliday. Dessa forma, o nível representacional, que abriga a predicação, está relacionado com o evento narrado, o enunciatário compreende a que situação se faz referência. Já o nível interpessoal está relacionado com o evento de fala, o enunciatário reconhece a intenção comunicativa do enunciador. Já que trabalhamos com narrativas orais, verificamos como os locativos apareciam distribuídos na narrativa e para isso também nos valemos de Hopper (Cf. HOPPER, 1979, 1982; HOPPER e THOMPSON, 1980 apud RODRIGUES, 1996), que nos apresentou os planos narrativos - Narrativo ( $1^{\circ}$ plano) e Comentário ( $2^{\circ}$ plano). O plano narrativo é aquele que carreia as informações principais e que normalmente apresenta verbos no pretérito perfeito em português nas narrativas de eventos passados. Já o comentário é aquele que traz as informações secundárias, aquelas que de fato tecem algum comentário sobre o que foi dito no plano narrativo, e geralmente os verbos estão no pretérito imperfeito em português nessas narrativas. Com base nisso, verificamos com que tipo de plano os locativos estariam mais associados, dependendo do EsCo em que se encontrassem.

No Capítulo 3, descrevemos o corpus sob análise, apresentamos informações sobre: o Projeto Filologia Bandeirante, o Banco de Dados do Português Popular Falado na Cidade de São Paulo e a variedade lingüística popular.

Vimos que a variedade de português popular constitui uma variedade lingüística eminentemente de cunho oral, não codificada e não normalizada e que tende a modificar-se com maior vitalidade.

O capítulo 4 abrangeu a descrição, análise e interpretação dos dados. Na primeira parte deste capítulo, expusemos os contextos e fatores analisados para se determinar em que ocasião os locativos desempenhariam a função de argumento e satélite na oração. Já na segunda parte apresentamos os resultados da análise, os quais foram estabelecidos a partir dos cálculos fornecidos pelos programas computacionais do Goldvarb. 
Os resultados confirmaram todos os nossos pressupostos formulados na Introdução deste trabalho. Verificamos que os locativos aqui, aí, ali e lá podem exercer tanto a função de argumento como a função de satélite em uma oração; mais que isso, os locativos em nosso corpus apareceram mais com a função de argumento - $65 \%$ das ocorrências, do que com a função de satélite - 34\% do total. Observamos que os EsCos de Posição e Estado favorecem o aparecimento dos locativos com a função de argumento, enquanto os EsCos de Ação e Processo privilegiam a função de satélite. Notamos ainda que apesar de os locativos apresentarem uma grande mobilidade na oração, quando eles assumem a função de argumento tendem a permanecer logo após o verbo, ao contrário de quando têm a função de satélite, quando apresentam um comportamento mais livre. Por último, constatamos que o plano Narrativo favorece o aparecimento de locativos com a função de satélites, já que estes estão relacionados aos EsCos de Ação e Processo e estes EsCos apresentam verbos mais dinâmicos, enquanto os locativos com a função de argumento estão mais concentrados no plano Comentário, que favorece o aparecimento de EsCos de Posição e Estado, que são menos dinâmicos.

Assim, a análise levou-nos a estabelecer os contextos de uso que mais favorecem os locativos com a função de argumentos, são eles:

- junto de EsCos de Posição e Estado;

- ocupando a posição 3, logo após o predicado;

- contextos em que não há possibilidade de seu deslocamento no eixo sintagmático da oração;

- integrando o plano Narrativo.

Já os contextos que favoreceram o aparecimento dos locativos como satélites foram:

- junto a EsCos de Ação e Processo;

- ocupando as posições 1( inicial) ,2 (antes do verbo) e 4 ( depois do objeto);

- contextos em que há a possibilidade de deslocamento no eixo sintagmático da oração;

- integrando o plano Comentário.

Vimos, dessa forma, que houve uma polarização entre as duas funções. Os contextos de uso para quando os locativos assumem ou a função de argumento ou a 
Dessa forma, comprovamos em nosso corpus que os locativos adverbiais não podem ser apenas considerados como meros acessórios em uma oração. Suas funções vão além, eles podem ser argumentos de predicado, enquanto dêiticos, e também conector de texto, como é o caso do locativo aí, quando este não é um locativo prototípico. Assim, o locativo aí quando está na posição inicial aparece com muita freqüência com a função de conector de texto ou marcador discursivo. Tais achados vão de encontro com o que alguns gramáticos e lingüistas já anunciavam e mostram que não é possível alocar todos os advérbios em uma única classe de palavras, já que eles desempenham funções sintáticas, semânticas e discursivas diferentes e possuem, assim, características peculiares.

Dessa forma, vemos que o Funcionalismo atendeu a todas as necessidades de nosso trabalho, dando-nos subsídios para uma investigação que procurou relacionar as propriedades sintáticas e semânticas às textuais.

Esperamos que nossa pesquisa tenha contribuído para uma melhor compreensão dessa classe tão heterogênea que é a classe dos advérbios. Sabemos que apesar dos muitos estudos já existentes, esse assunto certamente não está esgotado. Os próprios dados já nos sugerem questões de análise para o futuro, tais como o comportamento dos advérbios junto a preposições, como em expressões como pra lá, de lá, até aqui, etc. Estudos posteriores podem também verificar em que medida os fatores selecionados como estaticamente significativos em nossa pesquisa atuam em outros corpora representativos das variedades lingüísticas do português do Brasil. 


\section{BIBLIOGRAFIA}

BACK, E.; MATTOS, G. Gramática Construtoral da Língua Portuguesa. São Paulo, FTD. 1972.

BECHARA, E. Moderna Gramática Portuguesa. 37. ed. rev. e ampl.. Rio de Janeiro, Lucerna. 2001.

BERLINK, R. A.; AUGUSTO, M. R. A.; SHER, A. P. Sintaxe. In: MUSSALINI, F., BENTES, A.C. (orgs). Introdução a lingüística, vol.2. São Paulo, Ed. Cortez. 2002.

BLANCHE-BENVENISTE et al Pronom et syntaxe. SELAF, Paris 1984 apud CASTILHO, A.T. de A língua falada no ensino de português. Contexto, São Paulo. 2001.

BOMFIM, E. Advérbios. Ática, São Paulo. 1988

BORBA, F. S., et al Dicionário Gramatical de Verbos do Português Contemporâneo do Brasil. Editora UNESP, São Paulo. 1990, p.145 - 170.

CAMACHO, R. G. Estrutura Argumental e Funções Semânticas. ALFA, vol.43, 1999.

CASTILHO, A. T. de A língua falada no ensino de português. Contexto, São Paulo. 2001 .

Um ponto de vista funcional sobre a predicação. ALFA, vol. 38, 1994, p. 75-95.

A Predicação Adverbial no Português Falado. Tese de Livre Docência, FFLCH-USP, São Paulo. 1993

CHOMSKY, N. Knowledge of language: its nature, origin and use. New York, Praeger.1986.

COHEN, M.A.A. Pressupostos Teórico-metodológicos do Projeto Filologia Bandeirante. In: MEGALE, H. (org.) Filologia Bandeirante: Estudos 1. São Paulo, Humanitas, FFLCH/USP, 2000, p. 211-222.

COHEN, M.A.A. et al. Filologia Bandeirante. In: Filologia e Lingüística Portuguesa, São Paulo, Humanitas, 1997, 1:79-94.

CUNHA, C. F. da; CINTRA, L. F. L. Nova Gramática do Português Contemporâneo $9^{\circ}$ ed.. Rio de Janeiro, Nova Fronteira. 2001

DIK, S. et al. The hierarchical Structure of the clause and the typology af adverbial satellites. In: NUYTS, J; BOLKSTEIN, A.M.; VET, C. (ed). Layers and levels of representationin language theory: a functional view.Amsterdan, Benjamins, 1990, p.25-70. 
The Theory of Functional Grammar. Dordrecht: Foris.1989.

DILLINGER, M. Forma e Função na Lingüística. D.E.L.T.A. vol 7, n.1, 1991, p 395407.

FERNÁNDEZ, F. M. Principios de sociolingüística y sociologia del lenguaje. Barcelona, Ariel. 1997.

HALLIDAY, M.A.K. An Introduction to Functional Grammar. Baltimore: Edward Arnold. 1985.

HENGEVELD, K. Adverbs in Functional Grammar.In: WOTJAK,G(ed). Towards a functional lexicology.Towards a functional lexicology. Berlin: Peter Lang. 1997, p.121-136.

KATO, M. A. Formas de Funcionalismo na Sintaxe. D.E.L.T.A. vol.14, 1998, p.145168.

KURY, A. G. Novas Lições de análise sintática. Ática, São Paulo. 1991.

ILARI, R. et al. Considerações sobre a posição dos advérbios.In: Ataliba T, de C.(org) Gramática do Português Falado: a ordem. 2. ${ }^{\circ}$ ed. Campinas, Unicamp/Fapesp. 1991, p 63-141.

LUFT, C. P. Moderna gramática brasileira. 12º ed. São Paulo, Globo. 1994.

MACAMBIRA, J. R. A estutura morfo-sintática do português. $2^{\circ}$ ed. São Paulo, Pioneira. 1974.

MARTELOTTA, M.E. Os circunstanciadores temporais e sua ordenação: uma visão funcional. Rio de Janeiro, UFRJ, tese de doutorado. 1994.

MATTOS E SILVA, R. V. De fontes sócio-históricas para a história social lingüística do Brasil: em busca de indícios. In: MATTOS E SILVA, R. V. (org.) (2001) Para a História do Português Brasileiro. São Paulo, Humanitas, FFLCH/USP, vol. II, tomo II, 2001, p. 275-301.

MATTOSO CÂMARA JÚNIOR, J. Dicionário de Linguistica e Gramática. $23^{\circ} \mathrm{ed}$. Petrópolis, Vozes. 2002.

História e Estrutura da Língua Portuguesa. Rio de Janeiro, Padrão.1975.

MENDES, S. T. P. Que língua falavam os bandeirantes na região de Minas Gerais? In:

MEGALE, H. (org.) Filologia Bandeirante: Estudos 1. São Paulo, Humanitas, FFLCH/USP, 2000, p.65-75.

MIOTO, C.; SILVA, M. C. F.; LOPES, R. E. V. Manual de Sintaxe. Florianópolis: Ed. Insular. 2000. 
MIRA MATEUS, M. H. et al. Gramática de Língua Portuguesa. Lisboa: Ed. Caminho. 1989.

NEVES, M. H. M. Gramática de Usos do Português. São Paulo, Editora UNESP. 2000.

A Gramática Funcional. Martins Fontes, São Paulo. 1997.

Uma visão geral da gramática funcional. Alfa, vol.38, 1994, p.109-127.

Os advérbios circunstanciais de lugar e tempo. In: ILARI, R. (org.) Gramática

do português falado: níveis de análise lingüística. $2^{\circ}$. Ed.Campinas, Unicamp, 1992, p.261-296.

NÓBREGA, M. H. Análise Funcional de advérbios e adverbiais modalizadores no texto jornalístico. Dissertação de Doutorado, FFLCH/USP. 2000.

NOGUEIRA, R. M. O advérbio locativo no português popular de idosos. Relatório de Iniciação Científica apresentado à FAPESP, 2003.

OLIVEIRA, M. Para um programa de análise lingüística do português falado na trilha dos bandeirantes. In: MEGALE, H (org.) Filologia Bandeirante: Estudos 1. São Paulo, Humanitas, FFLCH/USP, 2000, p. 223-235.

PERINI, M.A. Gramática descritiva do português. $2^{\circ}$ ed. São Paulo, Ática. 1996.

PEZATTI, E. G. Teoria da Gramática Funcional. In. The 2003 International Course and Reference in Role and Reference Grammar. Unesp/ São José do Rio Preto, 14 a 20 de julho de 2003.

Uma abordagem funcionalista da ordem de palavras no português falado.

ALFA, vol. 38, 1994, p. 37-56.

PEZATTI, E. G.; CAMACHO, R. G. Aspectos funcionais da ordem de constituintes.

DELTA (online), vol 13, nº2, 1997, p 191-214.

PONTES, E. Espaço e Tempo na Língua Portuguesa. Campinas, Pontes. 1992.

RISSO, M.S. O articulador discursivo "então". In: CASTILHO, A.T.; BASILIO, M.

(org) Gramática do Português Falado. v.IV. Campinas, Ed., da UNICAMP/FAPESP, 1996, p.423-452.

ROCHA LIMA, C. H. Gramática Normativa da Língua Portuguesa. $31^{\circ}$ ed. Rio de Janeiro, José Olympio. 1992.

RODRIGUES, A. C. S. Sociolingüística Correlacional. Comunicação apresentada no 53 Seminário do GEL, UFSCar, São Carlos. 2005. 
RODRIGUES, A. C. S. \& CAMPOS, O.G. L.A.S. Reflexões sobre fatos de nãoconcordância verbal no português culto brasileiro. São Paulo, Comunicação apresentada no Congresso da ALFAL, Costa Rica, 2002.

RODRIGUES, A. C. S. \& FERREIRA NETTO, W. Transcrição de Inquéritos: problemas e sugestões. In: MEGALE, H. (org.) Filologia Bandeirante: Estudos 1. São Paulo, Humanitas, FFLCH/USP, 2000, p. 171-193.

RODRIGUES, A. C. S. et al. Formas de pretérito perfeito e imperfeito no indicativo no plano textual-discursivo. In: KOCH, I. G.V. (org) Gramática do Português Falado, v. VI. Campinas, Ed. da UNICAMP/FAPESP, 1996.

RODRIGUES, A.C.S. A concordância verbal no português popular em São Paulo. São Paulo: USP. Tese de Doutoramento. 1987.

SAID ALI, M. Gramática Secundária e Gramática Histórica da Língua Portuguesa. $3^{\circ}$ ed. rev. e ampl. Brasília, Editora Universidade de Brasília. 1964.

TARALLO, F. A pesquisa sociolingüística. São Paulo, Ática. (Série Princípios). 1985.

VOTRE, S. Um paradigma para a lingüística funcional. In: NEVES, M.H.M.; BRAGA, M. L.; PAIVA, M. C. (org) ALFA, vol. 41, São Paulo, 1997, p. 25-40. 